形態学上、物理的性質上打上ひ生化学的性 質上差がない人毛のケラチン监白の低硫黄ケ ラチン画分にっ電気泳動的变異型が存在する ことがBaden (1) らにより発見されて以 来充らに高硫黄画分にも变異型が報告（3）, され遺伝性も確認されている。このケラ チン蛋白の型は人類遺伝学上、鑑識科学上有 効な標識であると考えられる。

今回我々は日本人頭毛についてケラチン煌 白变異型の檢討を行つたので報告する。 実験材料扣よび方法

毛䟦は日本人男女68名（4才から58才）の頭 毛の毛根部を除いた毛幹部を用いた。各資料は 中性洗戍、エタノール：エーテル (1: 1) で 洗浄後デシケータ中に保存して用いた

ケラチン蛋白の抽出、調製はBaden (2) の方法 に準じて行つた。すなわち毛髪 $10 \mathrm{mg}$ 細切し 10 mlの0. 2M2 - amino- 2- methyl- 1,3propanediol, 0. 2M2- mercaptoethanol, $8 \mathrm{M}$ urea ( pH10.0) に浸漬し、窒素ガス下で $50^{\circ}$ C,3 hrs 処理し、遠沈上清をヨード酢酸でアル キル化（pH9．０）乙蒸留水に対して透析後、 8Murea濃度にしてからメンブレンフイルヌー で約 20 倍に濃縮し、0.01Mtris・HCl buffer ( $\mathrm{pH} 8$ ．3）に対して透析し $\mathrm{S}$ - カルボキシメチ ルケラチン溶液約 $1 \mathrm{ml}$ (蛋白濃度 $5 \%$ 前後) を 得る。

電気泳動はLee (3) 万の方法に従つて行つ た。すなわち低硫黄ケラチンの分析用には7 $\%$ polyacrylamide gel (6Mureat含む、 $\mathrm{pH} 8$. 9)、高硫黄ケラチンの分析用には17.5 $\%$ polyacrylamide gel (6M ureaを含む、 $\mathrm{pH}$.9) を用いて通常の濃縮ゲル（6M urea を含む、 $\mathrm{pH} 6.7)$ をつけデイス法で、電極 buffer $0.01 \mathrm{M}$ tris.glycine, $3 \mathrm{M}$ ureaを 含む $(\mathrm{pH} 8.3)$ を用いて泳動した。

結果

1 低硫黄ヶラチンは通常 4 本のバンドに分れ $\left(\begin{array}{ll}\mathrm{Fig} & 1\end{array}\right) 、 68$ 例中变異型は1例も認め5 れなかつた。

2 高硫黄ケラチンは通常 5 本のバンドに分れ 、变異型はバンド1己2の間に過剩バンドが 現れる（Fig 2) もので、68例中 15 例認め られた。正常型 4 例、变異型 12 例の個体の 18ケ月間を打いて採取した毛䯽について検 討したところ、各々18ケ月前のパターンと 同じ型を示し同一個体での再現性は確認で きた。

\section{文献}

(1) H.P.Baden etal, Am. J. Hum. Genet. 27,p472,1975

(2) H.P.Baden, Biology and Disease of the Hair p129, University of Tokyo Press, Tokyo, 1976

(3) L.D.Lee etal, Forensic Sci. 11,p115, 1978

(4) R.C.Marshall, J.Invest.Dermatol. 75 , p264, 1980

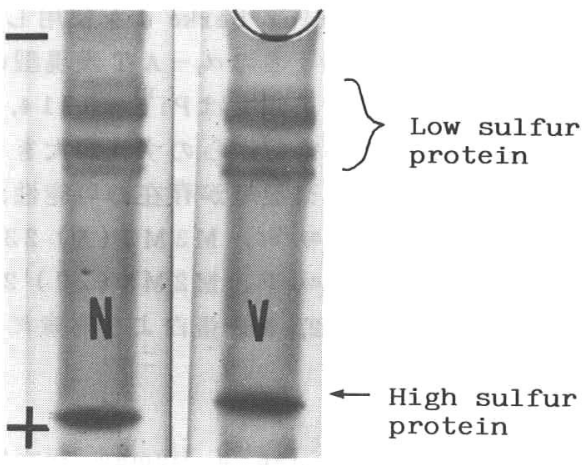

Fig.1 7\% polyacrylamide gel electrophoretic patterns of normal (N)( Japanese) and variant(V)(Caucasian) hairs.

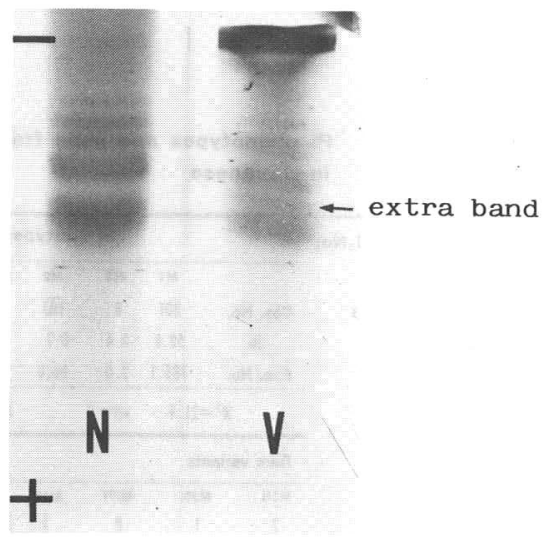

Fig.2 17.5\% polyacrylamide gel electrophoretic patterns of normal(N) and variant(V) high sulfur hair proteins. 


\section{2. 日本人における $\alpha_{1}$ - アンチトリプシン表現型の分布 - 6 種M悪型の分布及び方の血清 $\alpha_{1}$-アンチトリプシン值一 ○三宅和彦・鳥居正男・大国䉆史・中村孝司・山中正己 \\ (帝京大 $\cdot$ 医・第 1 内科)}

$\alpha_{1}$-アンチトリプシン（以下 $\alpha_{1}-\mathrm{A}$ T と略す）はgenetic polymorhism を示す血清糖蛋白で ある。日本人では，アジア諸国に共通した特徵である稀有型が少なく，M M が99\%以上と压倒

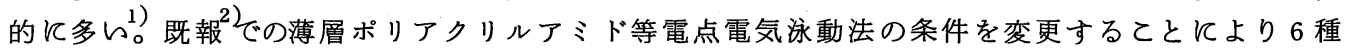
の M 亜型（M1M1，M3M3，M2M2，M1M3，M2M3，M1 M2）の安定した良好な分離パターンを得た。 日本人成人の $\alpha_{1}-\mathrm{A} T$ 表現型の分布及び $\mathrm{M}$ 亜型の $\alpha_{1}-\mathrm{A} T$ 值を測定したので報告する。 <試料及び方法> 対象は東京在住の日本人健康者 1543 名である。等電点電気泳動法はMuliphor 装置（Ｌ K B ）を用いて, 既報少のゲルを $4{ }^{\circ} \mathrm{C}$ の冷却下に1 $2 \mathrm{~W}$ の定電圧で 7 時間泳動した。 $\alpha_{1}-\mathrm{AT}$ 值はM-Partigen（Behring Berke）を使用した。 $\alpha_{1}-\mathrm{AT}$ 表現型の命名法はCox ら ${ }^{3}$ 亿従った。 〈結果及び考察〉 1543 名の $\alpha_{1}-\mathrm{A}$ T 表現型の分布は表の通りである。稀有型は少なく, 0.45 \%である。 $\mathrm{M}$ 亜型の遺伝子頻度は $\mathrm{Pi}^{\mathrm{M} 1}=0.714, \quad \mathrm{Pi}^{\mathrm{M} 2}=0.250, \quad \mathrm{Pi}^{\mathrm{M} 3}=0.036$ であり欧米のそれ とほ婹一致する。をだ期待值からのずれが大をく，Hardy-Weinberg の法則に合致していない。 M 1 と M 3 の間にさらにM 亜型が存在の可能性があると推定された。 M亜型の $\alpha_{1}-\mathrm{A}$ T 值は, M $1 \mathrm{M} 1$ ( 25 ) $265 \pm 36 \mathrm{mg} / \mathrm{d \ell}$, M $3 \mathrm{M} 3$ ( 5 ) $231 \pm 16 \mathrm{mg} / \mathrm{d \ell}$, M $2 \mathrm{M} 2$ (25) $208 \pm 21 \mathrm{mg} / \mathrm{dl}$, M $1 \mathrm{M} 3$ ( 25 ) $249 \pm 22 \mathrm{mg} / \mathrm{d} \ell$, M $2 \mathrm{M} 3(20) 234 \pm 18 \mathrm{mg} / \mathrm{d \ell}, \mathrm{M} 1 \mathrm{M} 2(25) 238 \pm 18 \mathrm{mg} / \mathrm{dl}$, であった。M1 蛋白はM 2, M 3 蛋白より有意に低值であった $(\mathrm{P}<0.02)$ 。

文 献

1) Miyake, K. et al : Jap. J. Human Genet. 24, 55, 1979

2）三宅和彥 他：生物物理化学, 23, 275, 1979

3) Cox, D.W. et al : Hum. Genet. 53, 429,1980

$\mathrm{Pi}$ phenotypes and gene frequencies of PiM subtypes

in Japanese

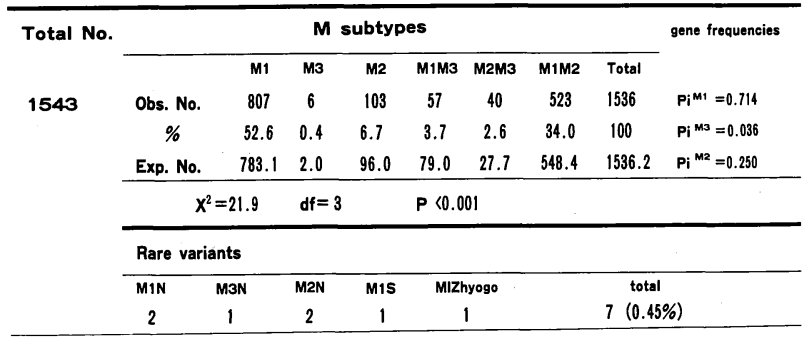




\title{
3. ヒト各種フェリチンの多様性について
}

\author{
○浅 川 英 男 (東京医歯大·医・中検) \\ 森亘 (東大·医·病理)
}

目的：フェリチンはその由来により等電点、鉄含有量などに相違が認められる。ヒトの組織フェリチンでる酸 性側にシフトした等電点を有するるの、塩基性側にシフトした等電点を有するフェリチンが認められる。他方悪 性董痬組織フェリチンは酸性フエリチンであり、かつ鉄含有量は少ない。しかし腫痬性フエリチンが、正常フエ リチンと比較して本質的な相違を有するものではないとの報告すあり、今回主として原発性肝癌フエリチンにつ いて比較検討をこてろみた。

材料および方法：フエリチンは肝癌組織、白血病組胞、胎盤、胎児肝（２０週）、正常肝を用いた。フエリチ ンの精製法は、组織ホモシネートを $75{ }^{\circ} \mathrm{C} 、 10$ 分間加熱、急冷後 $\mathrm{pH}$ を 4.8 亿調製し、3,000 r pm 20 分 間遠心、上清を集め、飽和硫安を等量加えて、一夜和を、䍿日3,000 rpm 20 分間遠心後上清を捨てた。沈澱 物を蒸溜水にとかし、再び $3,000 \mathrm{rpm} 、 20$ 分間遠心し、上清を集めた。その容量に対して $40 \%$ の $\mathrm{CdSO}_{4}$ を加え、 $\mathrm{CdSO}_{4}$ の終濃度を 5 \%になる上らに加える。約 1 週間低温室に静置後3,000 r pm 20 分間遠心し、 沈澱を物にとかし、その溶液をSephadex Gー2 0 ○でゲル沪過を行った。得られたフエリチンは7. 5 \%

Polyacrylamide gel で電気泳動を行い単一のバンドであるととを確認して用いた。

Polyacrylamide gel 電気泳動法は、Orstein \& Devis の方法で行った。

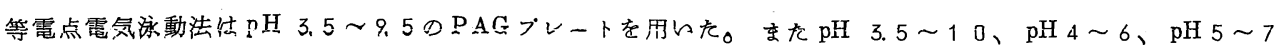
の ampholincを用い、終濃度を $2 \%$ とし、Polyacrylamideは4\%のるのを用いた。

酸性ティスク電気泳動法は、Panyim \& Cha1 Kleyの方法に従い、 15 \%のPolyacrylamide gel、6.25 Mのurea pH 3.2のデイスクで電気泳動法を行った。各種フエリチンのサブュニットの作り方は、Lavoie Harrison \& Gregoryの方法によった。各種フェリチン濃度は、ローリー法で、牛血清アルブミンに換算した ののを用い、含有鉄量は原子吸光装置で測定した。

成績：1. 免疫電気泳動法でみると、白血病細胞フェリチン、肝癌組織フエリチン、早期胎盤フエリチンは、 正常朋、正常脾フエリチンに比較して易動度が早かった。2. $\mathrm{pH} 3.5 \sim 10$ の等電点分画法の泳動像でみると 白血病細胞フエリチン、胿癌フエリチン、早期胎盤フェリチンは、正常挢、正常脾フェリチン飞比較してよい酸 性側にシフトしたバンドを認めた。 3. 白血病細胞フエリチン、肝癌フエリチンの鉄含量は少なく、 $\mathrm{Fe} / \mathrm{P} の$

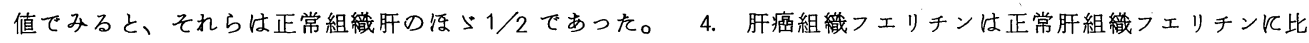
較して、等量の組織から、はじめたとき最終フェリチン精製量は肝癌組織では正常組織のほす1/2であった。 5. RーPHA 法で各種フェリチンを比較するとAHPF. 用いたとをは、AHLFを用いたときょり、腫瘍組織 フエリチンでや〉高い凝集素価を得た。 $\quad 6 .{ }^{125} \mathrm{I}$ 標識胎盤フエリチン抗血清、 ${ }^{125} \mathrm{I}$ 標識ヒト肝フエリチン抗 血清で、各種フエリチンを測定したとてろ、白血病細胞フエリチン、肝癌細胞フエリチンでは、胎盤フエリチン 抗血清を用いて測定した方がやつ高い值を示した。？．サブュニット構造をLavoieの方法で検討した成績か ら、レずれのフェリチンも2〜3本の近接したバンドのみを認めた。 8. Harrison \& Gregoryの方法でサブ ユニットに分解、酸性ディスク電気泳動法検討した成績では、正常組織フェリチンと腫瘍組織フエリチンは明ら か反相違する像を得た。

考案および結語

腫晹性フエリチンが正常フエリチンと比較して、電気泳動法で易動度が早く、鉄含有量は少く、酸性アインフェリチンの 像を示すととを肝癌フェリチン、白血病細胞フエリチンで示した。免疫学的にもRIA 法、R-P H A法を用いて、その標 準曲線のパターン、凝集素の相違から認妨てとがでをる。乙れらの相違の生ずる理由についてサブュニット構造について 検討を加えたとてろ、分子量的には2つ乃至了つのサブュニットが認められ相違するとは言い難いが、酸性ディスを用い る方法からはバンドが相違する像を示し、サブュニット構造についてさらに検討を加え、その相違につけて明らかにする必 要を認めた。 


\section{Con-A および LcH に対する \\ 親和性の差に基づくヒト AFP の分子多様性 \\ ○武田和久・泉 正樹・渡口えり子 (香川大・医・保健管理センター)}

ヒトの $\alpha$ - fetoprotein (AFP) は Concanavalin A ( Con-A) および Lens culinaris hemagglutinin ( LcH) に親 和性を有する分子種の存在するととが Kerckaert ら ${ }^{1)}$ によって示され, 肝細胞癌患者の A F P は症例によりL c H に対する親和性に差のあるととを宮崎ら ${ }^{2)}$ は明らかにしている。演者らは肝細胞癌が産生する A F P の L c H に対 する親和性に差のある分子種の特性を明確にするため, 親和カラム・クロマトグラフィーおよび親和交叉免疫電気 泳動を行い, 興味ある知見を得たので報告する。

材料および方法：

原発性肝癌患者腹水（蛋白量 $21 \mathrm{mg} / \mathrm{ml}, \mathrm{AFP} 50.000 \mathrm{ng} / \mathrm{ml}$ ) を凍結保存したものを材料とし, Con一Aカラムを用 いた親和クロマトグラフィーおよび第32回電気泳動学会総会で演者が発表した高感度親和交叉免疫電気泳動により, レクチンに対する親和性の異る AFP の分子種を分離, 検出した。Con-AおよびCon-A SepharoseはPharmacia 社, $\mathrm{LcH}-(\mathrm{A}+\mathrm{B}), \mathrm{LcH}-\mathrm{A}$ および $\mathrm{LcH}-\mathrm{B}$ は $\mathrm{E} ・ \mathrm{Y} \mathrm{Lab}$.社のものを用い, $\mathrm{AFP}$ とレクチン複合物の解離常数 $\mathrm{K}$ およびァルブミンに対する相対移動度 Rmc は B $\phi \mathrm{g}$-Hansen およびTakeo ${ }^{3)}$ の方法によって求めた。

結果 :

Con-Aカラムを用いた A F P の親和クロマトグラフィーの非結合分画は, 再クロマトグラフィーにより, $\mathrm{Con}$ - A 亿親和性を有しない電気泳動上単一のピーク, $\mathrm{AFP}_{1}(\mathrm{Con}-\mathrm{A})(\mathrm{Rmc}=0.86)$ に示し, 弱結合性および 結合性分画は $\mathrm{Con}-\mathrm{A}$ に親和性を有する単一のピーク, $\mathrm{AFP}_{2}(\mathrm{Con}-\mathrm{A})(\mathrm{K}=0.55 \mathrm{mg} / \mathrm{m} \ell, \mathrm{Rmc}=0.55)$ を示した。 $\mathrm{AFP}_{1}\left(\mathrm{C}_{\mathrm{on}-\mathrm{A}}\right)$ は $\mathrm{L} \mathrm{cH}-\mathrm{A}$ にも親和性を示さず, 乙の分子種を $\mathrm{AFP} \mathrm{P}_{1}(\mathrm{Con}-\mathrm{A}, \mathrm{LcH}-\mathrm{A})(\mathrm{LcH}-\mathrm{A}$ に関 し, $\mathrm{Rm} \mathrm{c}=0.89)$ とした。 $\mathrm{AFP}_{2}(\mathrm{Con}-\mathrm{A})$ は $\mathrm{L} \mathrm{cH}-\mathrm{A}$ に弱い親和性を有し, 移動度の遅れが少い $\mathrm{AFP}_{2,2}\left(\mathrm{C}_{\mathrm{on}}\right.$ - A , L c H-A ) ( L c H-A 飞関し $, \mathrm{K}=0.52 m \mathrm{~m} / m \ell, \mathrm{Rmc}=0.79)$ と $\mathrm{c} \mathrm{H}-\mathrm{A}$ に親和性を有し, 移動度の遅れが大 きい $\mathrm{AFP}_{2},{ }_{3}(\mathrm{Con}-\mathrm{A}, \mathrm{LcH}-\mathrm{A})(\mathrm{L} \mathrm{cH}-\mathrm{A}$ に関し, $\mathrm{K}=0.17 \mathrm{mg} / \mathrm{ml}, \mathrm{Rmc}=0.54)$ の 2 分子種から成るととが 明らかとなった。 $\mathrm{L} \mathrm{cH}-(\mathrm{A}+\mathrm{B})$ を用いた場合には， L c H-A を用いた場合に近い A F P 亜分子種の分離が得ら れた。L c H-B も AFP 3 分子種に分けたが, Con-A との差は僅かであった。 結語 :

$\mathrm{C}$ on-A 結合性, L c H-A弱結合性の A F P が肝細胞癌で変動を示す分子種と考えられた。 文献 :

1) Kerckaert, J. - P. et al. : Biochim. Biophys. Acta, 576:99 (1979).

2) 宮崎 純ほか：肝臟, 22:1559(1981).

3) B $\phi \mathrm{g}-$ Hansen, T. C. and Takeo, K. : Electrophoresis, $1: 67(1980)$. 


\section{EIA法によるAFPの迅速定量法の研究 \\ ○野中則孝・西山政一・守永留司・本永秀夫 (シノテスト研) \\ 日比 望・平井秀松 (北大・医・第 1 生化学) \\ 西 信三 (山梨医大·生化学)}

A F P は、腫痬マーカーの一つとして、その測定は臨床的にも大きな意義がある。従来、A F P の測定は、信頼性 などの面から R I A 法が沉用されていたが、近年、R I A 法の欠点を補うべく同等の感度を有し、さらに短時間で測 定できる E I A 法が開発され急速に広まりつつある。今回、我々は、A F P 測定用のE I A ( 洰紙ディスクを担体と するサンドイッチ法）の系を組み、一定の感度を有し、かつ、より短時間で測定できる系の確立を目的として検討し た結果、若干の知見を得たので報告する。

【材料扣よび方法] 担体（抗体結合ディスク）は、直径 $5.5 \mathrm{~mm}$ の沪紙ディスクを用い、Pーアミノフェノール存在 下、エポキシ化によりアミノ基を導入し、架橋剤としてグルタルアルデヒド（ＧＡ）を用いて抗体を固定化した。酵 素標識抗体（ＡＬＰ結合抗体）の酵素は、仔牛小腸粘膜由来の A L P を用い、酵素と抗体の結合は、G Aを架橋剤と して用いるAvrameas の方法に準じて行なった。A F P の測定は、抗体結合ディスクに血清中のA F P 反応させ [第 1 反応、室温、 2 時間〕、洗浄の後、A L P 結合抗体を反応させた〔第 2 反応、室温、2 0 時間】。次いで、デ ィスクを洗浄後、抗体結合ディスクに結合した A L P の酵素活性を測定した〔酵素反応系、 $37{ }^{\circ} \mathrm{C} 、 40$ 分〕。

〔結果] 1. A L P 結合抗体の濃度による影響 第 2 反応において、A L P 結合抗体の濃度を変化させ、その影響を みたところ、濃度の増加により効力の上昇がみられた。この知見より、第 2 反応のインキュベーション時間の短縮が 可能となった。これに伴い第 1 反応のそれも短縮化できた。〔第 1 反応 : 2 時間 $\rightarrow 1$ 時間、第 2 反応 : 20 時間 $\rightarrow 2$ 時間了。2. 反応条件による影響 上記 1 . と同一試薬を用いた場合、インキュベーション条件により、第 1 ・第 2 反応 時間を短縮化できるか検討した。その結果、振盪器の振濭回数を約 300 回/分、振幅 $30 \mathrm{~mm}$ (温度 $37{ }^{\circ} \mathrm{C}$ ) と振㬈速 度と振幅の増加により効力の上昇がみられた。この知見より、“高速振盪器 “を用いることにより、第 1 ・第 2 反応 のインキュベーション時間を一層短縮化できた。これに伴い、酵素反応時間も短縮化できた。〔第 1 反応： 1 時間 $\rightarrow$ 30 分、第 2 反応 : 2 時間 $\rightarrow 30$ 分、酵素反応 : 40 分 $\rightarrow 30$ 分了。3. 短時間測定法の評価“高速振盪器”を用い た場合の成績は、従来のものと変わらず良好であった。同時再現性、拓よび日差再現性は、表 1.に示したような良好 な再現性が得られた。本法と R I A 法との相関関係は、 $\mathrm{n}=74 、 \mathrm{r}=0.980 、 \mathrm{Y}=0.986 \mathrm{X}-3.2$ ( X : R I A 法、Y：本法）と良好な結果が得られた。

[考察〕以上の結果より、本測定系への“高速振盪器”の導入により、A F P の測定をより短時間で、しかも正確 に行ならことが可能となった。本法のような抗体が固定化されているような場合の抗原一抗体反応は、抗原と抗体の 反応に何らかの制約をらけると思われる。㬰際、本担体を用いた場合、第 1 反応はほとんど温度の影響をらけないの に対し、第 2 反応は温度の影響をらけること。また、第 1 反応のタイムコースは、比較的短い時間内でプラトーに達 するのに対し、第 2 反応のそれは、経時とともにゆるやかに進むといった現象が見い出されている。本法による短時 間測定法実現のためには、このような制約を緩和することが必要と考劣、まず、反応がより制約をうけやすい第 2 反 応に扔いて、抗原と抗体との反応性を高めるため、相対的に抗体の量を增やす、すなわち、A L P 結合抗体の濃度を 増加した。次いで、抗原と抗体との反応を時間的にはやめるために振盪器の振盪速度、振幅を高めた。この結果、見 かけ上抗原一抗体反応が短時間で進み、測定法の短縮化が実現した。なお、担体がプラスチックビーズの場合には、

“高速振盪器”を用いても測定時間の短縮化はなされなかった。本法のような、“高速振盗器”を用いる短時間測定 法は、担体の種類が大きな因子になると思われる。

1) Avrameas, S., Immunochem istry; $\underline{6}, 43 \sim 52$ (1969).

表 $1 . \quad$ 同時再現性および日差再現性

\begin{tabular}{|c|c|c|c|c|c|c|c|c|c|}
\hline & \multicolumn{2}{|c|}{ repeatability } & \multicolumn{2}{|c|}{$(\mathrm{N}=10)$} & \multicolumn{3}{|c|}{ reproducibility } & \multicolumn{2}{|c|}{$(N=10)$} \\
\hline$A F$ & S ample a & Sample b & Sample & $\mathrm{c}$ & Sample & 1 & Sample & 2 & Sample 3 \\
\hline $\bar{x}(\mathrm{ng} / \mathrm{ml})$ & 90.3 & 224.0 & 338.0 & & 54.4 & & 192.5 & & 392.0 \\
\hline S. D. & 4. 99 & 10.47 & 17.5 & & 6.01 & & 11.36 & & 23.47 \\
\hline C. V. (\%) & 5. 5 & 4.7 & 5.2 & & 11.1 & & & & \\
\hline
\end{tabular}




\title{
6. マイクロプレートを用いた
}

\section{酵素免疫測定法による流血中 Immune Complex の測定}

\author{
○島 村 幸 夫・松 村 利 徳(東京クリニカルラボラトリー) \\ 荻良 晴 (三光純薬)
}

流血中の Immune Complex (以下 IC と略す)の検出法としては，現在までて数多くの方法が開発され,そのうちのいくつかは,すで に日常検査飞導入されている。

今回,われわれは三光純薬におりて, マイクロブレート法として開発された，新しいＩＣ測定法について検討したので報告する。 測定法の概要

ヒトCIq マイクロブレートの内壁に付着させ,てれと反応した IC 中の Ig-Gをアルカリフォスファターゼを標識した抗ヒトIg一G 抗体と反応させる。さらに基質, 呈色試薬を加え $490 \mathrm{~nm}$ で測定し,あらかじめ作製しておいた aggrega ted human Ig-G(AGG) による標準曲線に基づ々て, AGG量に換算した I C 量を求める。

検討方法ならびに材料

本測定法に基づ々て AGGの標準曲線，測定濃度範囲，再現性等の基礎的検討と，健常人，およびSLE患者血清などを用いた各種榆 討を行なった。なお健常人血清につけては，当センターの職員より採血し，さらに日常当センターに検査依頼の中から,各種検査デ ーターに異常のみとめられなかったものを使用した。をた患者血清については, 日大板橋病院より提供していただいた。

検討に用いた試薬は以下のでとくである。

1. CIq Solution：ヒト新鮮血清加ら米増法に基づ々て精製したもの。

2. AGG：ヒト Ig-G $63{ }^{\circ} \mathrm{C}, 20$ 分間加熱し, Sephadex G-200で分画したもの。

3. その他の試薬： ALP 標識抗七ト I g-G 抗体, 基質液, 呈色試薬, Serum diluent

成績および考察

$\mathrm{AGG}$ 標準曲線は図ー1のような曲線を示し, 本法の測定感度は $1 \sim 3 \mu \mathrm{g} / \mathrm{m} 1$ と思われた。標準曲線の日差再現性 $(\mathrm{n}=6)$ は表 -1 に示すように良好であった。

本法による当センター職員 14 例の測定結果は,すべて $3.0 \mu \mathrm{g} / \mathrm{ml}$ 以下であった。 また定期健康猃断として検査依頼のあった 66 例 では, 63 例が $3.0 \mu \mathrm{g} / \mathrm{ml}$ 以下で, 3 例は, それぞれ 3.5, $6.0,7.4 \mu \mathrm{g} / \mathrm{ml}$ であった。SLE 患者血清 16 例では図一2 2 示すよらに 10 例が $3.0 \mu \mathrm{g} / \mathrm{ml}$ 以上であった。また抗DNA抗体陽性血清 57 例について本法で測定したとてろ,図ー3に示すような結果が得られた。

以上の検討結果よりみて, 本法は IC の検出法として, 日常検查に導入可能であり，特に操作が簡便なため,多数の検 体を処理する場合などにきわ有用であると考える。今後はさらに，本法によって検出されるICの性状などについて も,引を続を検討を加えたい。
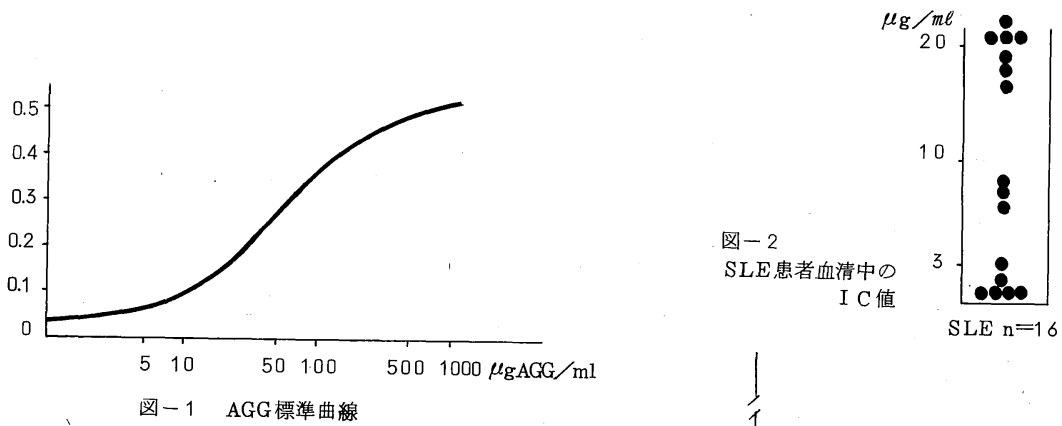

図一 1 AGG 標準曲線

\begin{tabular}{l|c|c|}
$\begin{array}{l}\text { 表 }-1 \\
\text { 標準曲線の } \\
\text { 再現性 } \\
\mathrm{n}=6\end{array}$ \\
\cline { 2 - 3 } & AGG $\mu \mathrm{g} / \mathrm{m} \mathrm{l}$ & $0 . \mathrm{D} \overline{\mathrm{x}} \mathrm{ISD}$ \\
\hline 1 & $0.02 \pm 0.01$ \\
\hline 5 & $0.05 \pm 0.01$ \\
\hline 10 & $0.08 \pm 0.01$ \\
\hline 50 & $0.21 \pm 0.02$ \\
\hline 100 & $0.31 \pm 0.05$ \\
\hline 500 & $0.46 \pm 0.03$ \\
\hline 1000 & $0.52 \pm 0.03$ \\
\hline
\end{tabular}

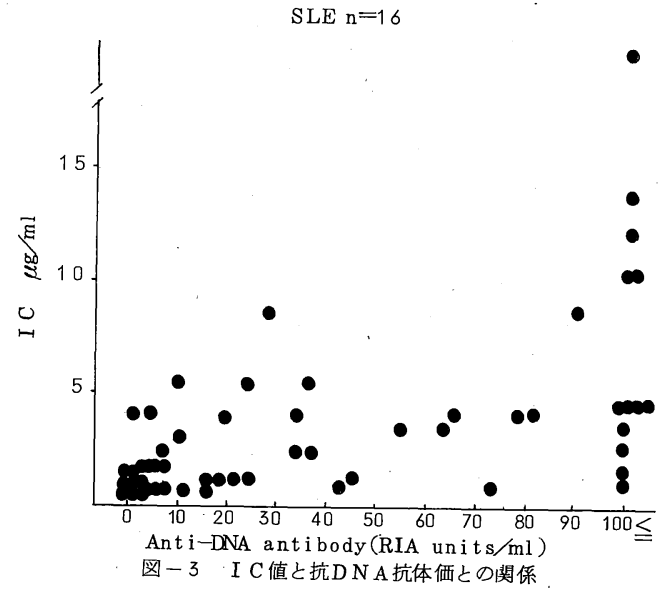




\title{
7. Sjogren's syndrome 患者
}

\author{
耳下腺唾液の電気泳動像について \\ ○吉田 治弘・日野原 博・池本 卯典 (自治医大.人間生物) \\ 水野 正浩・ 三好 俊二・森田守 (自治医大. 可鼻咽喉科学)
}

Sjögren's syndrome 患者の耳下腺唾液の電気泳動像について、D. M. Chisholm らは等電点電気泳動法によっ て検討し、健常者耳下腺唾液の泳動像に比して amylase よりも陽極側に特異的と思われる蛋白質 band を観 察している。私達は自治医科大学附属病院耳鼻咽喉科外来において、Sjögren's syndrome の疑いのあると診断 された10名の患者について耳下腺唾液を採取する機会を得たので、水平式の等電点電気泳動法、垂直力ラム式 の等電点電気泳動法ならびに disc-polyacrylamide gel 電気泳動法などの電気泳動法によって、それらの耳 下腺唾液を泳動し、その泳動像を観察した。

\section{○実験材料および方法}

患者の耳下腺唾液は自治医科大学附属病院耳鼻咽喉科外来に通院する患者10名より耳下腺唾液を Carby 法 によって採唾し、一部を残して透析後、凍結乾燥したのち約10倍濃縮になるように蒸留水で溶解調整した。

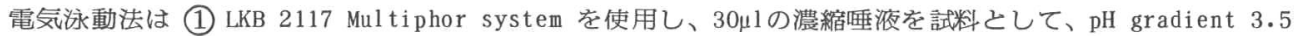
〜 9.5で等電点電気泳動を 300V. 17mAの通電で開始し、1000V. $5 \mathrm{~mA}$ で約 2 時間泳動した。(2) 垂直力ラム式 の等電点電気泳動は内径 $5 \phi \times 90 \mathrm{~mm}$ のガラス管に pH gradient 3.5〜9.5になる様に polyacryl amidegel を作 製し、陰極槽に $0.1 \mathrm{M} \mathrm{NaOH}$ 、陽極傮に $0.1 \mathrm{M} \mathrm{H}_{3} \mathrm{PO}_{4}$ を入れ、未濃梨宿の唾液 $50 \mu 1$ を試料として、100V. $12 \mathrm{~mA}$ 通 電で開始し、400V． $5 \mathrm{~mA}$ で約 2 時間泳動した。司disc-polyacrylamide gel 電気泳動法は濃縮した唾液の $20 \mu 1$ を 試料として、Orstein \& Davis の方法によって泳動を行った。

\section{実験結果}

等電点電気泳動像：健常者の喠液の泳動像に比較して alkali 側の bands の濃度が極めて淡いかないし は欠落するような傾向を示した。（添付写真 1 参照 )

disc- 等電点電気泳動像 ： 健常者偊液、患者喠液ともに acid 側に major な数本の band を認める。 な お、alkali 側に淡くてかなり幅の広いband を認める。患者哽液中にはその band と major な band との中 間に 1 本の band の現われるものもあった。（添付写真 2 参照 )

disc- 電気泳動像 ：健常者の唾液には、血清蛋白の albumin 領域に相当すると思われる部位に band 認める。しかし、患者唾液のその部位の band は欠落していた。（添付写真 3 参照）

すでに、Chisholm（Oral. Surg., 5：9，1973）も報告しているように Sjögren's syndrome の耳下腺唾 液の各種電気泳動像は健常者耳下腺唾液とは多少異なった泳動像を示すものもあった。なお、調查例を蓄積し て㭘討したいと考えている。
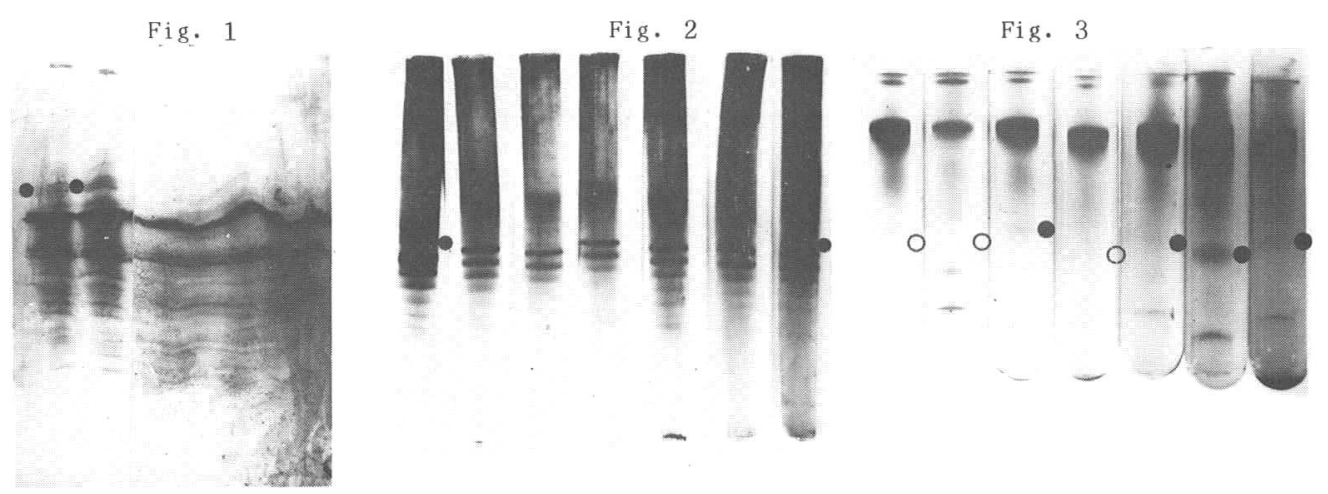


\title{
8.ヒト肝癌、実験肝癌の血中および組織中における
}

\section{azo色素結合蛋白 ligandinの動態と炎の意義}

\author{
○佐藤 鉄典・荒谷 英二・竹内 秀一・池田 晃 \\ 村上 俊吾・石谷 邦彦・添崎 一朗 \\ （札幌医大・第 4 内科）
}

Ligandin はrat やヒト肝、腎の可溶性分画飞存在する分子量46,000の塩基性蛋白質である。 その機能としてbilirubin、BSPなどの organic anion との結合による物質の摄取・輸送、 GSH S-transferase 活性飞よる細胞毒性物質の GSH抱合がある。一方、近年この ligandin が化学性発癌物質と結合することが報告され、発癌に扣ける ligandin の役割てついて興味が もたれている。今回我々は肝癌患者血清执よび癌組織中、実験肝癌を rat 扣よび nude mouse に移植し、腫場扎よび血清中 ligand in R I A 法を用い測定し、その動態を検討したので報告 する。

【方法】Ligandinはヒト拉よび rat の肝よりBassらの方法てて精製し、抗体は Marcus の 方法により作製した。RIA法はそれぞれの抗肝 ligandin 抗体を用い2 抗体法により行った。 対象は正常人 15 例、急性肝炎 26 例、慢性活動性肝炎 8 例、肝硬変 11 例、肝癌 19 例、他臓器癌の 肝転移症例 20 例の患者血清、術中採取した 15 例肝癌組織 $100,000 \times \mathrm{g}$ 上清とした。動物実験に はratの Morris 肝癌を使用し、rat 抢よび nude mouse 皮下に移植し、生着增大した腫瘤の $100,000 \times \mathrm{g}$ 上清扔よび血清 ligandin 值を経時的飞測定した。また Rat ligandin の RIA 采 に护ける nude mouse liver の免疫学的反応についても検討した。

【結果】正常人血清に ligandin 值は $7 \mathrm{ng} / \mathrm{m \ell}$ であったのに対し肝癌血清中 ligandin は中等度 に上昇がみられた。肝癌組織中には正常肝の $16 \%$ li gand in が認められた。肝への他臓器癌 転移症例では一部症例を除さ正常人と同程度の血清 ligandin 值であった。実験肝癌移植 rat 12例中 9 例飞生着が認められ、腫瘤中には正常 rat 肝組織の $40 \% の$ ligandin が認められ、それ 5 rat 血清中 ligandin 值も正常 rat 飞比し有意飞高值を示した。 Rat ligandin のRIA system そ执いて nude mouse 肝上清は交叉反応を示さなかった。実験肝癌移植実験を nude mouse そ対して行らと、腫瘤の増大に伴って血清 ligandin 増加が認められた。

【結論】肝癌患者血清 ligandin 上昇の機序について肝癌組織中に li gandin が存在すること、 rat p nude mouseへの肝癌移植実験で示された如く腫瘤増大に伴 5 血清 ligandin 上昇が認 められ、分化度により肝癌に ligandin 産生性のものがあると推測される。また発癌に対する ligandin の防御機序あるいは癌化に伴 5 異 ligandin 出現の可能性も示唆された。 


\section{9.スルホサリチル酸可溶性蛋白に関する検索 \\ ○金森きよ子・佐野紀代子 (東京医歯大・医・中検) \\ 中尾真 (東京医歯大·医·第 1 生化学)}

微量蛋白の測定法として、Coomassie Brilliant Blue G-250(CBB)を用いる方法が、1976年 Bradford rより初めて報告された。我々は本法を尿蛋白の測定法として自動分析機へ導入する方法を考案した。 本法と従来日常検査法として採用していたスルホサリチル酸（ S S A ）法との相関をみたとてろ、10 0 mg/d l 程 度の蛋白濃度の検体におらて両法の值にから離がみられ、C B B 法で高值を示す検体に遭遇した。そてでから離の みられた検体について、S D S ポリアクリルアミドゲル（ＳＤ－－ＡＧ）電気泳動により検索したとてろから離 の原因はムコ蛋白に由来する事が推定されたので報告する。

方 法

尿蛋白測定法：我々の開発したオートアナライザー川型による自動化法によった。S S A 法はKingsburyー Clark 法に準じた。そしていずれる標準液はモニトロール】を用いた。

S S A 処理法：尿及びS S A の濃度は、Anderson 法飞準じたが、その1/40 量とした。すなわち、酢酸々性 尿 $1 m \ell k 10 \%$ S S A $0.25 m \ell$ を加充、室温 20 分放置後、3，000 回転 20 分遠心した。

加熱処理法：Purdy 法飞準じた。

尿中ムコ蛋白の調製法：正常人ブール尿上りTamm \& Horsfallの塩析法及びAnderson \& Maclaganの安 息香酸吸着法の両法で調製分離した。

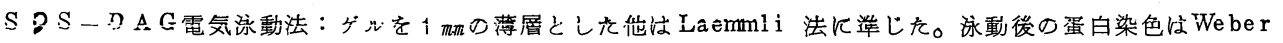
らのCoomassie Brilliant Blue R-250、シッフ染色はZacharius らの方法に準じた。

結 果

1) C B B 法とS S A 法との相関

約 1,000 例の患者尿飞つレて両法の相関をみたとてろ、相関係数 0.92 と良好な結果を得た。しかしながら、 $100 \mathrm{mg} / \mathrm{d} \boldsymbol{l}$ 以下の蛋白濃度を示した 195 例にっんてみると、相関係数は 0.79 と悪くなった。その原因は、 両法の值が合致するるのの依かかなり両方法の值がかけはなれている検体があったためであった。C B B 法の 值がS S A 法より 2 倍以上の高值となった検体は 34 例で、1 $7.4 \%$ を占めた。それらの検体の疾患名を検索し たところ、種々の悪性腫痬及び S L E と診断された症例が多かった。

2) S S A 処理と加熱処理した上清部分の蛋白濃度の相関

15 例飞つを、S S A 処理及び加熱処理した各々の上清をC B B 法で測定したととろ、 $\mathrm{y}=1.0 \mathrm{x}-0.95$

( $\mathrm{y}: \mathrm{SS} \mathrm{A}$ 処理、 $\mathrm{x}:$ 加熱玑理) 相関係数 0.85 と汪等しい值を得た。

3) S S A 処理と加熱処理した上清蛋白の S D S - P A G 電気泳動像と推定分子量

症例に上り原尿の蛋白バンド及びその濃度パーセントは多種多様であった。しかしながら、S S A 処理及び加 熱処理した上清蛋白の泳動像は検体が異ってるほ医類似した泳動像を示した。上清部分蛋白は 11 亿分画され、 その分子量は 7.8 万から 1.2 万であった。その主バンドは 6.4万、 $4.5 \sim 5.0$ 万、 $4.5 \sim 3.7$ 万で、てれらのバ ンドで全体の $50 \%$ 濃度を占めた。また、シッフ染色したととろ主バンドが濃染されたととから糖蛋白であると ちがわかった。

以上のととから、S S A 可溶性部分にみられた蛋白は、酸可溶性、熱凝固せず、しかもシッフ染色で濃染された ととからムコ蛋白であろらと推定した。 


\title{
10．ヒトlgDに関する研究
}

\section{第 2 報：Radioimmunoassay法および}

\author{
Latex凝集法によるIgDの微量測定法について \\ ○荒川 正明・榎本 博光・伊藤 喜久・櫻林郁之介・河合 忠 \\ (自治医大・臨床病理)
}

目的） I $g \mathrm{D}$ は B 細胞膜表面に多く存在する免疫グロブリンであるが、その機能については未だ解明されていない。 その原因として、I $g$ Dが分解しやすい性質を有することに加えて、IgDの微量測定法が開発されていないことが上

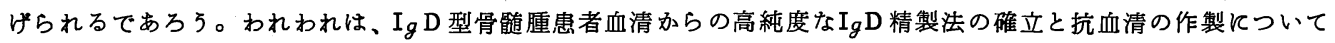
すでて報告している(第 32 回電気泳動学会)。今回、精製したIgD扰よび抗血清を用いて Radi oi mmunoassay （RＩＡ）法、ラテックス凝集法（ＬＦＴ）を開発し、市販の標準 $I_{g} D$ および抗血清との比較検討、ならびにヒト血清 中のI $g$ D 量を測定し、一元放射状免疫拡散（ S R I D ）法との比較検討を行ったので報告する。

方法）ＲＩＡ（二抗体法）：精製 Ig DをクロラミンT法にょりラベルし、Sephadex G-75を通し遊離の ${ }^{125} \mathrm{I}$

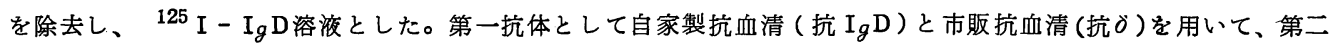
抗体に抗ウサギ I $g$ G（ヤギ）を用いた二抗体法により測定を行った。また、標準 $I_{g} D$ して精製 $I_{g} D$ と市販の標準 Ig D （ＳＲＩＤ用、B 社、H社およびM社）の 4 種類を用いた。測定は以下の手順で行った。まず、 ${ }^{125} \mathrm{I}-\mathrm{I} g \mathrm{D}$ 溶液を $100 \mu \ell$ ずつ分注し、標準 $\mathrm{Ig} \mathrm{D}$ および検体を $100 \mu \ell$ 加え、さらに第一抗体を $200 \mu \ell$ 加え $37^{\circ} \mathrm{C} て ゙ 18 \mathrm{hr}$

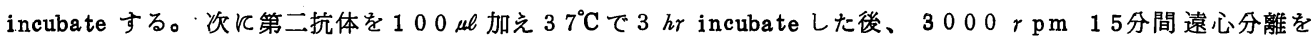
行い上清を除去し、 $r$-カウンターで放射能を湘定した。標準曲線を作り血清中のI $g \mathrm{D}$ 濃度を求めた。

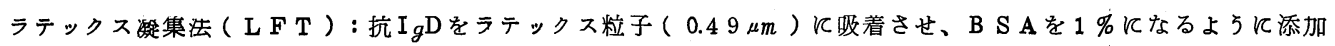
し、抗 $I_{g} D$ 感作ラテックス液を作製した。溉定方法は、まず標準 $I_{g} \mathrm{D}$ 扣よび検体を反応板に $50 \mu \ell$ と、これに抗 $\mathrm{I}_{g} \mathrm{D}$ 感作ラテックス液を $25 \mu \ell$ 加え、反応板を動汃し 3 分間よく混和した後、反応板に生じる凝集像を肉眼で判定 する。あらかじめ標準 $I_{g} \mathrm{D}$ の希釈系列を作り凝集の切れ目を見つ汁出し、潰感度としておく。検体も希釈系列を 作り、凝葉の切れ目を見つけ、抗I $g \mathrm{D}$ 感作ラテックス夜の感度に乘じて検体中のIgD濃度を算出した。

また、S R I D 法はM B L社製プレートを用いた。各剆定法の相関はヒト血清 26 例を用いて求めたが、SRID 法で測定できる血清は 12 例であった。

結果・考察）ＲＩＡ法に扣いて、検体の代わりに緩衝液を加えた時のカウント（Bo）が総カウントの約半分にな

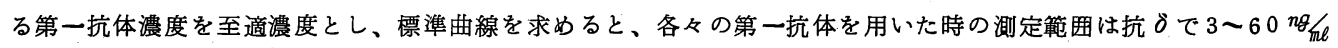

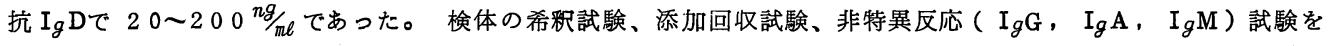
行ったところすへて満足のいく結果であった。また、標準 $\mathrm{I}_{g} \mathrm{D}$ して F $\mathrm{c}$ 。を用いた場合、抗 $\mathrm{I}_{g} \mathrm{D} て ゙ は 1,000$ ng ml

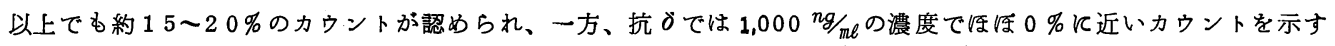
ことから、やはり市販抗血清抗

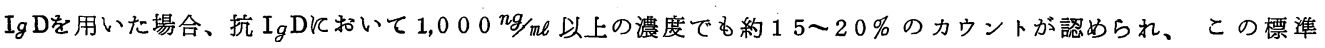
$\mathrm{Ig} \mathrm{D}$ はF $\mathrm{F}_{\mathrm{c}}$ ठではないかと考えられる。L F T K招いて、標準 IgD から検出限界濃度を求めると約 $125 \mathrm{ng} / \mathrm{ml}$ であり、 標準 IgD間の盖屾認められなかった。 S R I D法との相関を求めると、R I A - S R I Dで $r=0.9221$, L F T - S R I Dでれ

以上、I $g$ D 微量測定法としてR I A 拈よびL F Tを確立した。L F T は半定量法であるが、微量測定のスクリ ーニング法として有用であり、R I A は精密定量可能な測定法であると考えられる。また、標準 $\mathrm{I}_{g} \mathrm{D}$ の問題、検体 の取り扱いなど、湘定に怙ける種々の条件について検討し、その結果についても報告する予定である。 


\section{1. 寒天ゲルと反応性を示す \\ $\operatorname{lgG}_{3}-\mathrm{K}$ 型多発性骨䯣腫例の免疫化学的研究}

○藤 田 清 貫(花園病院·研究検查)

\footnotetext{
今回, セルロース・アセテート膜 (以下七・ア膜) 電気泳動で, $\mathrm{s} 10 \mathrm{w}$ - $\mathrm{r}$ 位にM-蛋白を認めたが, 寒天ゲル免疫電気泳動では slow - r 位にM - 蛋白を証明し得ず, $\mathrm{fast}-\mathrm{r}$ 位と原点のB位KM-蛋白を認めた症例老経験した。

この症例につんて免疫化学的解析を行った結果, 興味ある知見が得られたので報告する。

I 症例

57 才男性。1978 年 10 月 5 日より某病院にて多発性骨䯣腫の診断で入院加療。

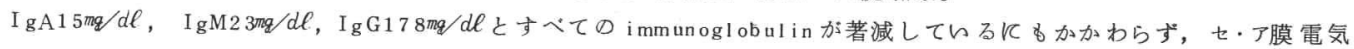
泳勳でSIow-r 位にMー蛋白带が証明された。しかし, 寒天ゲル免疫電気泳動ではslowーr 位にMーbow が觀察されなか ったととから, 当検查科へ解析の依頼があった。
}

III実験方法および結果

1. 七・ア膜電気泳動飞和ける所見

Separax, Sepraphore III, Sartori us 膜を用いてセ・ア膜電気泳動を行った結果，いずれの支持体とおりてもslow-r 位 飞明瞭な M-蛋白帯を認めた。

2. 免疫電気泳動飞叔济所見

$1.2 \%$ アがース・寒天等量混和平板を用いて行ってみると, $\mathrm{s} l$ ow $-\mathrm{r}$ 位には M-蛋白注認められず, fast-r位にK

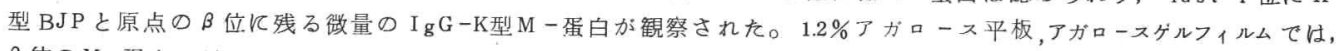
B 位の M-蛋白は消失し, fast-r位とslow-r位KM-bow 死認めた。(Fig.1)

3. 寒天ヶルとの反応性

深さ $1 \mathrm{~mm}$, 直径 $2 \mathrm{~mm}$ の孔飞, 原血清, 精製 $\mathrm{IgG}$ 型 $\mathrm{M}$ 一蛋白, 正常血清, 高乳ビ血清死各々 $2.5 \mu \ell$ 注入し, 室温にて 24 時間拡散させた。その結果, 原血清と 精製 I g G 型M - 蛋白にのみ沈降輪形成が羿的られた。 4. ゲル漁過における所見

SephadexG-200を用いたカラムゲル滤過法にて觬察 してみると，IgG 型 M一蛋白は， G'分画に溶出され， aggregation を起しているととが示唆された。

5. I gG subclass の同定

Mi I e s 社製の I gG subclass 抗血清を使用し検索し たところ, 抗 $\mathrm{IgG}_{3}$ 血清とのみ反広した。

さらK, proteinA-Sepharose·CL-4Bを用いたアフィ ニティークロマトクラフイーで吸着されなかったととか ら, ての $\mathrm{M}$ - 蛋白は, $\mathrm{I} \mathrm{gG}_{3}$ 型 $\mathrm{M}$ 一蛋白と同定された。

III 考察

アがロース平板では, 七・丁膜電気泳動のM-蛋白带と 同じ位置にM-bow 認めたてと, 同一条件ですアカ口スに寒天を添加したたけで原点に M-蛋白が残ってしま らことを考えると, 今回の $\mathrm{IgG}_{3}$ 型 $\mathrm{M}$-蛋白には寒天と反 応する成分が含すれているすのと推察される。ただ, 従 来, イオン强度をあげると $\mathrm{M}$ 一蛋白と寒天との相互作用 が消失ないし軽減するととが知られているが, 今回の症 例壮 $0.06 \mathrm{M}$ から $0.1 \mathrm{M}$ 索でイオン強度をあげて子何ら变化 認好加てとから，寒天にあるといわれているイ オン交換体のよ5存作用1)2彵上るものでは路上5反思 われた。

今後, I gGの分子構造の解明と寒天のアカロベクチンに注目

し, 特に硫酸塩との関連性について娭討老加えたい。
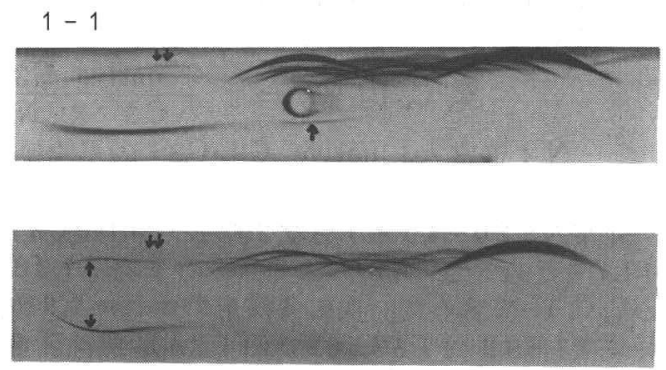

of the serum.

1-1: Agarose : Agar $=1: 1$

1-2: Agarose gel film

$\uparrow:$ IgG-Ktype $\mathrm{M}$-protein

$\uparrow \uparrow \quad$ : K type B J P

[文献]

1) 河合忠：血漿蛋白一その基礎と臨床一、1 版、 医学書院、東京、1977、P.178.

2) 高月清: 臨床免疫、13[ suppl .3] : 34, 1981 . 


\section{2. 補体活性の新しい測定法}

- $\mathrm{C}_{3}$ complement conversion index-

○ 中嶋憲章・柴田さとみ・佐々木清美・中嶋なつ子 (高野病院・免疫生化学)

韓綮司・杉崎 徹三 (昭和大 ·医 $\cdot$ 第 1 内科)

\section{I. 緒 言}

近年, 補体の研究の進歩と共に諸㣫疾患に抢ける補体の変動について多くの研究がなされ, 臨 床的意義が検討されて来た。補体成分值が異常である場合, その原因として補体の合成または異 化の異常が推定される。従って, 補体成分值の臨床的意義を検討する場合, その測定方法が問題 亡なる。今回, 我々はC 3 の conversionを利用した complement conversion index (C, C, I ) の浿 定法を検討し，各種疾患についてその成績を考察した。

II - 対象及び方法

1）対象：昭和大学第一内科，高野病院内科で診断されたA R Aの診断基準を満す R A 18 例, S L E 8 例, 種 々肝疾患 (肝硬変 16 例, 急性肝炎 7 例, 慢性肝炎 18 例 ） 41 例, 剖検によっ て確認された悪性腫痬 13 例, 糖尿病患者（インスリン抗体陽性 5 例, 陰性 10 例 ), 大動脈に 石灰化を認める動脈硬化症 12 例, HANE 1 例, $20 \sim 40$ 才までの健康人 20 名のEDTA 加新鮩 血漿について検討した。

2) 方法

(1) native $\mathrm{C} 3$ 及び $\mathrm{C} 3$ の測定

native $\mathrm{C} 3$ ( $\beta_{1} \mathrm{C}$ globul in) の測定は抗 native $\mathrm{C} 3$ 血清 (Kent 社 Lot. $1190 \mathrm{M} 1$ ) を用い, $\mathrm{C}_{3}$ ( $\beta_{1}$ $\mathrm{C} / \beta_{1}$ A globl in)はHyland社 Laser Nephelometer 用C 3 キットを用い, Laser Nephelomenter法で, 測定した。尚, 標準血清には QS 血清 (Hoechst 社) 0.01M, EDTA 加生理食塩水に溶解して用 い，てれを $100 \%$ として算定した。

(2) complement conversion index ( C, C, I ) の求め方

C, C, Iは下記の式によって求めた。

$$
\mathrm{C}, \mathrm{C}, \mathrm{I}(\%)=\frac{\text { native } \mathrm{C} 3}{\mathrm{C} 3 \times \mathrm{N}} \times 100
$$

$\mathrm{N}$ : 正常人〔 native $\mathrm{C} 3 / \mathrm{C} 3]$ の平均值 $(1.38$ )

III. 結 果

健常人 ( $20 \sim 40$ 才) 男女 20 例の native C 3 は平均 $165.4 \pm 20.6 \%$ であり, C3 は平均 $120.0 \pm$ $11.7 \%$ あ゙あった。 native $\mathrm{C} 3 / \mathrm{C} 3$ の平均は 1.38 であった。ての值を C, C, I $100 \%$ として, 各疾患 のC, C, I を求めた。次に各疾患の native C 3 值, C, C, I はSLE ( 75.4 肝硬変 $(89.9 \pm 17.6 \%, 69.0 \pm 11.2 \%)$, 西性腫痬 $(89.9 \pm 29.4 \%, 75.2 \pm 17.9 \%)$, 急性肝咨 $(110.1$ $\pm 26.3 \%, 70.1 \pm 9.9 \%)$, 慢性肝炎 $(127.8 \pm 27.6 \%, 78.0 \pm 6.3 \%), \mathrm{RA}(128.8 \pm 17.6 \%, 64.2 \pm 12.4$ \%), インスリン抗体陽性の糖尿病 $(136.8 \pm 23.0 \%, 68.0 \pm 6.31 \%)$, 陰性の糖尿病 $(157.7 \pm 19.9 \%$, $93.7 \pm 9.7 \%)$ ，動脈硬化 $(160.8 \pm 12.7 \% ， 92.5 \pm 10.8 \%), \operatorname{HANE}(115 \%, 96 \%)$ であった。

IV. 考察及び結論

現在, 補体活性の測定法として, 最むよく用いられているのが $\mathrm{CH}_{50}$ であり, 膠原病, 自己免疫 疾患の診断並びに病状把握に有効な手段となっている。 $\mathrm{CH}_{50}$ に比し, 最近一般化しつつある $\mathrm{C} 4$, C 3 等の補体成分の測定は血清中の蛋白量を測定しているが故に，かならずしも病状と相関しな いてとが知られている。特にC 3 亿ついては我々がすでに報告している如く, 従来は $\beta_{1} \mathrm{C} / \beta_{1} \mathrm{~A}$ の両生分の総和を測定しているが故にC 3 の活性と一致しない場合が多い。今回，ての点を改良 すべく， native $\mathrm{C} 3$ を測定する検討を試み， L. N 法による測定が簡便かつ迅速，正確であること を証明した。そこで $\beta_{1} \mathrm{C} と \beta_{1} \mathrm{C} / \beta_{1} \mathrm{~A}$ の比を求めることにより $\mathrm{C} 3$ の activationを指数化し，その 臨床的意義の検討を試みた。今回の成績によると低補体を呈するてとが知られている SLEでC, C，Iが低下したのは immune complexにより補体が activation され低值を示したと考えられたが， 高補体を呈するRAC゙低值を示したてとは大変興味ある所見である。すなわち， R A ではC 3 の conversionは行われているが, C 3 の合成も六進している為 C 3 全体では高值となると推測され た。その他の肝疾患, 悪性腫瘍, インスリン抗体陽性の糖尿病で C, C, I が低值であることより, これらの疾患に於いてあ, 何らかの機序により補体が活性化されている可能性があり，その意義 について更に検討する必要があると考えられた。 


\section{3. ᄂp (a)リポ蛋白の電気泳動像の特徵}

\section{○川出真坂・前田 悟司・飯田 久也 (岐皁大·医·中検)}

虚血性心疾患と高い正の相関性を有することが示されて以来、 L p (a)リポタンパクの生理的意義あるいは代謝についての関心が 高まっている。我々はアガロースゲル電気泳動法、ポリアクリ ルアミドゲル電気泳動法による L p (a)の検出ならびに L aurell R ncket 法および S ingle R adial I mmunodiffusion法による 免疫学的定量法について検討したので報告する。

\section{方法および成績}

1. アガロースゲル電気泳動法

5 社より発売されている 9 種のアガロースについて検討した 結果、Litex 社アガロース H S A に極めて鮮明なリポタンパク の泳動像が得られた。0.5\%アガロースゲルにウシ血清アルブ ミン $(0.2 \%)$ を添加し、イオン強度 0.025 で泳動したところ、 $\mathrm{Lp}$ ( a )は, 動された(F ig. 1 )。

2. ポリアクリルアミドゲル電気泳動法

Narayanの方法に準じたが、分離用ゲル濃度を $3.6 \%$ に調製 することにより、pre- $\beta$ とLp (a)の分離は著しく明暸となった (Fig. 2 )。

3. $\mathrm{L}_{\mathrm{p}}$ (a)特異抗血清の調製法

Albers の方法に若干の改良を加えて調製した。すなわち、 Lp (a) 高濃度の血清よりP roksch 法で分離した $1.055<\mathrm{d}<1.120$ 画分を抗原として家鬼に免疫した。 $\mathrm{Lp}$ (a) はアポタンパク B と L p (a) 特異抗原を有するため、L p (a)が極めて低い血清よりP roksch法 で分画した $\mathrm{d}<1.040$ 画分と、 $\beta$ ーリポタンパク非含有画分 の免疫家鬼血清への添加、吸収操作を繰り返して特異抗血清を 調製した。得られた抗血清が免疫泳動上、 $\mathrm{Lp}$ (a) 特異抗原との み沈降線を形成することが認められた。

\section{Laurell Rocket 法}

抗血清含有アガロース平板に被検血清 $3 \mu 1$ 添加し、 $1 \mathrm{~mA} / \mathrm{cm}$ で12時間 泳動により、Lp(a)濃度に比例した易動度の明瞭な rocketの形成が観察さ れた(Fig.3)。4種の標準血清を同時こ泳動して得られる娭量線汃ら、各検 体のLp(a) 量を算出した。本法の検出限界濃度は $2.5 \mathrm{mg} / \mathrm{d}$ lであった。

5. Single Radial Immunod if fusion 法

抗血清含有アガロース平板に検体 $3 \mu 1$ 添加し、室温で 48 時間放置後 固定染色し、沈降輪の直径を測定してLp(a)濃度を求めた(Fig.4) $13 \mathrm{~cm}$ 入 $9 \mathrm{~cm}$ の平板1枚で 91 検体の処理河能であり、また検出感度も極めて高く （検出限界濃度、2.5 mg/d l) スクリーニングに最適である。

Lp(a)はアガロースゲル電気泳動法、ポリアクリルアミドゲル 電父泳動法においても、バンド幅が狭く、尖鋭に泳動されるの か溡徵である:

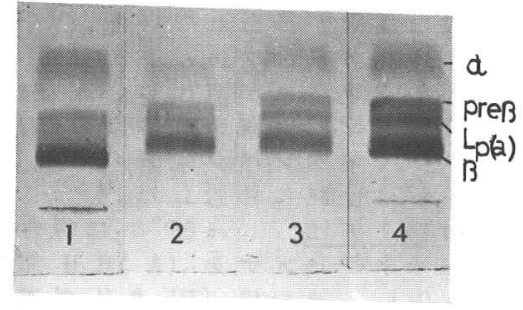

Fig.1 Agarose Gel Electrophoresis

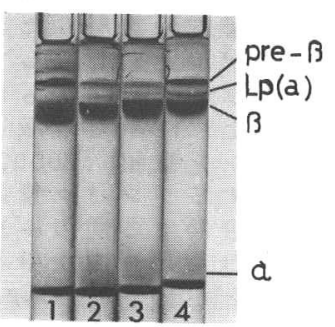

F'ig. 2 Folyacrylamide Gei Electrophoresıs

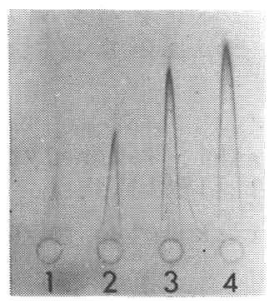

Fig.3 Laurell Rocket Electrophoresis

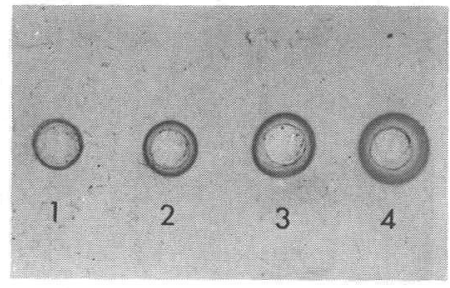

Fig.4 Single Radial Immunodiffusion
Lp (a) Concentration
1. $5.5 \mathrm{mg} / \mathrm{dl}$
2. $10.0 \mathrm{mg} / \mathrm{dl}$
3. $23.5 \mathrm{mg} / \mathrm{dl}$
4. $31.0 \mathrm{mg} / \mathrm{dl}$ 


\title{
14. 次元目にアガロースを用いた 2次元電気泳動法
}

\author{
平林 民雄・平井 秀一・山根明 (筑波大·生物科学)
}

一次元目にアクリルアミドゲルを用いた二次元電気泳動法は広く用いられ、多くの分野で 有益な成果が得られている。しかしこの方法にもいくつかの欠点が認められる。それは (1) 高分子ペプチッドが分析されない、（2）二次元目に移行する際のS D S 処理により 一部のタンパクが流出し、定量性が保たれにくい、（３）一次元目のバンドが記録出来ない (4) タンパク質分解酵素の作用を完全にはとめれない、なとである。これらを改良して より多くのタンパク成分の分析を可能にしたので、この方法を報告する。尚、詳細な説明 の一部は他誌に報告した。

材料と方法 $-80^{\circ} \mathrm{C}$ に保存したウサギとニワトリの横紋筋、平滑筋及び生きている織 毛虫テトラヒメナを（A）８Ｍ尿素、1 M KI、10\%2-メルカプトエタノール、0.1 m M

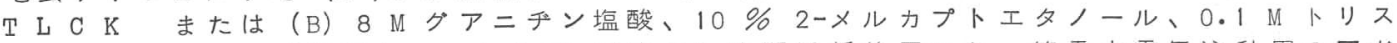
- $\mathrm{H} C \mathrm{Cl} 、 \mathrm{p} \mathrm{H} 7.5$ で処理し、これを7M 尿素に3 時間透析後用いた，等電点電気泳動用のアガ ロースゲルは表|に従って、酸性域、中性域、塩基性域にわけて調製し、内径 $2.5 \mathrm{~mm}$ 長さ $18 \mathrm{~cm}$ のガラス管内に重層した。500 V で24 時間泳動後、10\%TCA、5\%スルホサリシル酸 中にアガロースゲルをおしだして、時間処理し、沈澱したタンパク質のバンドを暗視野で写 真にとり、蒸留水で!時間洗った後、二次元目のアクリルアミト゚平板ケル上端にのせ寒天で 固定した。その上にSDS 処理液を3-5 mm の厚さに重層し、通常の電気泳動を行った。

結果ミオシン重鎖（200000 ダルトン）を代表とする大きな゚゚チ゚ッドもケ゚ル内に入り ゲル上端に残存するタンパク量は少なくなった。SDS 処理方法の改良により定量性がより保 たれた。二次に展開する前の一次のゲルパターンを暗視野て記録することが出来るために等 電点と分子量の軸により二次平面の位置を容 易に規定することが出来た (Fig.1b更に

（）を用いた方法では尿素の濃度を变えるこ とによりペプチッド間の複合体形成を検出出 来、（B）を用いた方法ではSDS 処理によって でも阻害しきれないタンパク質分解酵素を完 全に阻害することが出来た。(Fig.2)

文献

1) Hirabayashi, T. Analyt. Biochem. $117,443-451$ (1981).

Fig. 1 Rabbit skeletal muscle protein map

表 1 COMPOSITION OF AGAROSE GELS

\begin{tabular}{llllll} 
Ge1s & Acidic & \multicolumn{2}{l}{ Neutral } & \multicolumn{2}{l}{ Basic } \\
\hline Agarose & $0.02 \mathrm{~g}$ & $0.08 \mathrm{~g}$ & $0.04 \mathrm{~g}$ \\
Sorbitol & $0.24 \mathrm{~g}$ & $0.96 \mathrm{~g}$ & $0.48 \mathrm{~g}$ \\
D.W & $1.07 \mathrm{~m} 1$ & $4.04 \mathrm{~m} 1$ & $2.14 \mathrm{~m} 1$
\end{tabular}

D.W. $1.07 \mathrm{~m} 14.04 \mathrm{ml} 2.14 \mathrm{~m}$.

Ampholytes

$\begin{array}{lccccc}\text { pH2.5-5 } & 0.12 \mathrm{~m} 1 & - & - & \\ \text { pH3-10 } & - & 0.48 \mathrm{~m} 1 & - & \\ \text { pH4-6.5 } & - & 0.24 \mathrm{~m} 1 & - & \\ \text { pH } 8-10.5 & - & - & 0.24 \mathrm{~m} 1\end{array}$

Basic Acidic

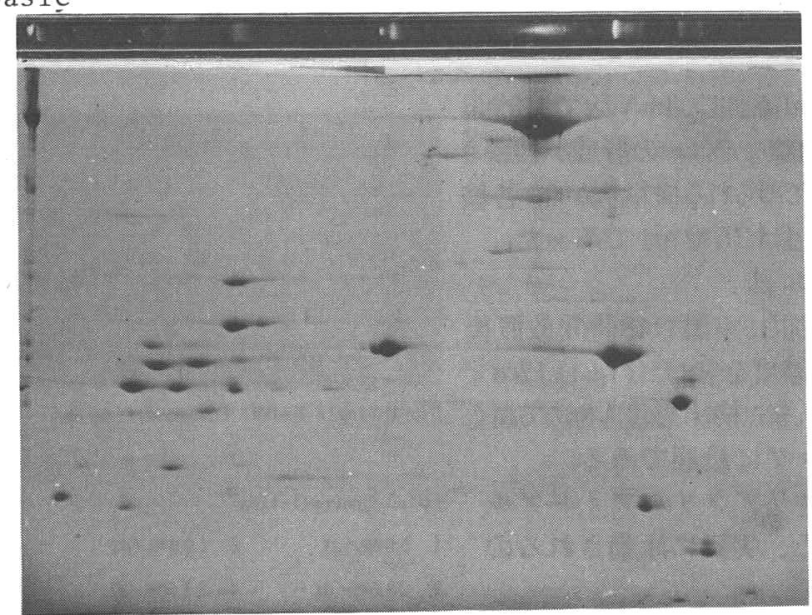

Fig. 2 Tetrahymena extracts

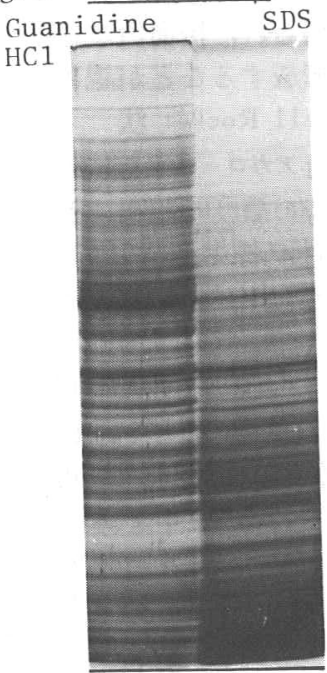




\title{
15. 2次元等電点－
}

\author{
SDS電気泳動法による癌関連細胞質蛋白の検出 \\ ○矢島 敏・高見 博・貞広荘太郎・川口 京・阿部令彦 $($ 慶応大・医・外科) \\ 石村 唭 (慶応大·医·医化学) 斘)
}

目的：O'Farrel1により開発された二次元等電点ーS D S ポリアクリアミド電気泳動法を改良 したTakami の方法 (Cancer Res. 399 ：5 $077 ， 1979$ ) はより少量の試料で一度に多数のゲ ルを簡便に泳動でき分解能あ優れている。最近，我々はさらに本法を工夫し，より短時間にかつ 蛋白分解能むより優れた方法を開発したので, 今回この新法を用いてヒト瘦組織の細胞質蛋白を 分離し，㴗関連蛋白質の検出を試みた。

材料と方法：手術時にえたヒト甲状腺の腫瘍組織とその周囲組織を用いた。腫瘍組織として癌 組織，良性腺腫を対象とした。組織は外科的に摘出後，ただちに細胞質蛋白を抽出した。また， 本泳動法の再現性を検討するため，正常ラット（ウィスター系 4 週粭，雌）肝の細胞質蛋白を用 いた。

細胞質蛋白の抽出は Cancer Res., 38 : 1514, 1978 に記されたごとく, Nonidet P-40 加緩衝液でホモジナイズし，得られた上清にエタノールを加え蛋白質を沈測させる。

二次元電気泳動法は乾燥した試料を $9 \mathrm{M}$ 尿素，2％アンフォリン，0.1 M D T Tに溶解後， 一次元目ゲル上に重層する。泳動槽の上タンクに0.0 $1 \mathrm{M}$ リン酸溶液（陽極），下タンクに0.02 $\mathrm{M} \mathrm{NaOH}$ 溶液(陰極) を注入し, 定電圧で通電する。泳動終了後, ゲルはアダプテーションバッ フォーにて 5 分間浸溋し反応を止める。二次元目の泳動はランニングゲルにスタッキングゲルを

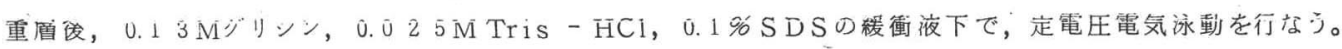
染色は $0.01 \%$ C B Bで, 脱色は $10 \%$ 酢酸, $10 \%$ イソプロピルアルコールで行なう。

結果：本法によるラット肝細胞質蛋白のスポットパターンは同時・異時の泳動とも写真に示したごとさ スポットパターンを呈し，その再垷性は極めて優れていた。また，蛋白スポットは260個に分離し得た。 甲状腺組織の検索では蛋白スポット数で澏組織 67 個, その周囲組織では 59 個であるのに対し, 良性

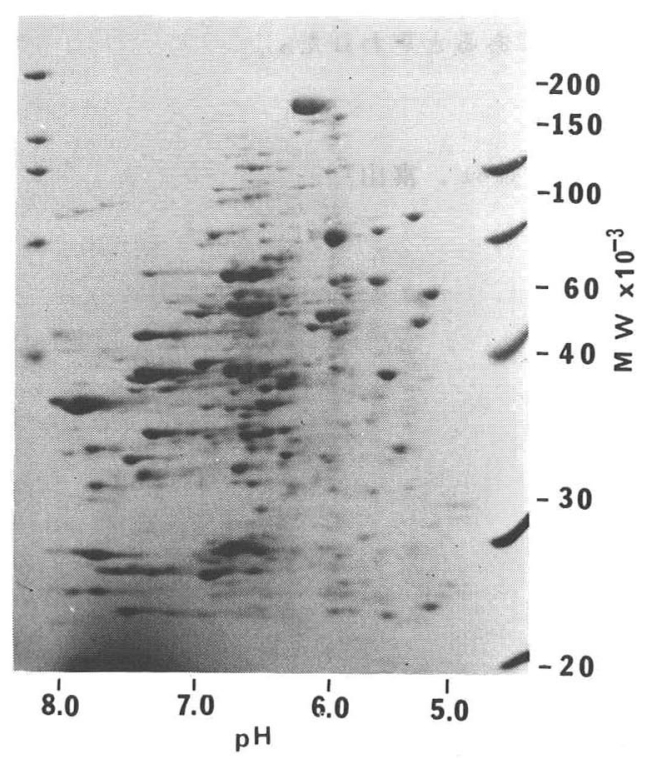
腺腫では６3 個, その周囲組織では 51 個となり, 酒組織のスポット数は良性腺腫のそれよりも多かっ た。次に, 癌組織のみにみられる㾞関連蛋白スポッ トは $55.8 / 5.4\left(\mathrm{MW} \times 10^{-3} / \mathrm{p} 1\right), 49.3 / 5.2$, $38.6 / 5.1,37.3 / 5.1,36.7 / 5.3,36.2 /$ $5.1,35.1 / 5.2,34.7 / 5.1,34.7 / 6.3$ の合 計 9 個となり，比較的低分子で酸性側にみられた。

結語：本法の再現性，分解能は極めて優れている。 甲状腺腫瘍による検索では 9 個の㽞関連細胞質蛋白 がみられた。これらが遺伝子調節蛋白である可能性 ああり, 現在蛋白の抽出 - 精製 - 一次構造の決定を 行なっている。 


\section{6. 重症肝疾患の血漿交換による \\ 治療における血漿蛋白の 2 次元電気泳動による検討 \\ 小田治・山中 直樹 (日本医動態研)}

はじめに）前回(1)劇症肝炎、肝硬変、肝癌など肝疾患者の血漿タンパクの2次元電気泳動沉 よる分析結果を報告した。今回、重症肝疾患などの治療法のエつで、患者血箓を、新鮮凍結血

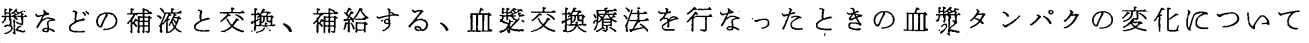
2 次元電気泳動によって分析、検討したので報告する。

方法）前回同棣、タンパク質変性剤を用いない。1次元目に 2 次元目に 4-1\% polyacrylamide gradient gel電気泳動を用いた。

試料）劇症肝炎（２例）、肝硬変（2例）の血獎交換前後の血鼎及び、その排液を用いた。 血獎交換用補液として新鮮凍結血鼎を用いた。

結果）血獎交換前の各血墏タンパクは、前回報告したように、4 例とも免疫グロブリンを除 いた大部分の血慧タンパクスポットの隇少傾向を示した。特にHDL、ハプトグロビン（Hp）、 へモペキッン（Hx）など12 啝のスポットの減少が激しかった。プレアルブミン、GCーグロブ

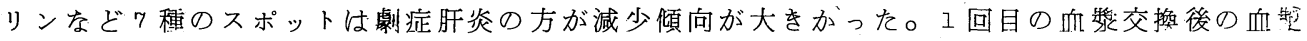
では上記飞示した、HDL、Hpなど大部分のタンパクスポットが増加傾向を示した。しかし、

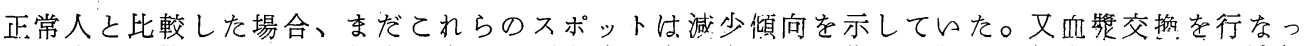

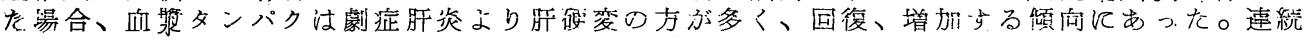
して血䈋交換を行なう過程で、初期の頃は血熋交換で多くのタンパクスポットが増加しても、

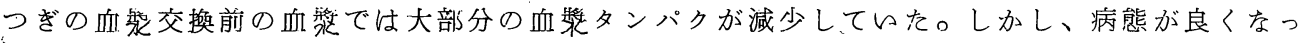
た患者では血獎タンパクスポットは除々に増加していた。ただしHp など数種のスポットは激し

く減少したままであった。又病態飞変化がない場合で流血菲タンパクスポットは病態が良くな

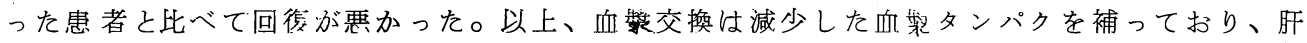
機能が回復するまでの血獎タンパクの補給として重要であると思われた。

(1).小田治他、第 32 回電気泳動学会総会講演抄録集（1981，富山） 


\section{7. 高感度 2 次元micro電気泳動法による \\ マイマイ抽出蛋白質の分析 \\ ○岩瀬三千雄・井上勤 (東京学芸大·生物)}

我々は、第32 回電気泳動学会総会において、2炊元 micro 電気泳動法について報告し、micro disc 電 気泳動法とともに微量試料の分析に 有効である事を示した。 今回 更に、2 次元 micro 電気泳動法に用 いる 実験器具、及び手法に検討を加え、マイマイ（Euhadra）の腷より分泌されている蛋白質 並びに 各 組織，消化液 及び 血リンパ液中の蛋白質を分析し、若干の知見を得たので報告する。

実験材料 及び 方法

1, ミスジマイマイ( Euhadra peliomphala ), 歹び セトウチマイマイ( Euhadra hickonis ) より摘出し た 腷神経組織より既報の手法によって回収した分泌蛋白質、及び 各摘出組織を Snail Ringer 液中 で破壊し 凍結融解を 3 回繰り返したものの上清、並びに 消化液, 血リンパ液を Snail Ringer液で 希釈したものを 泳動試料として用いた。

2,2 次元 micro 電気泳動法

gel の大きさ, 組成等は、前報に準じて行った。但し、/次元に用いる micro 等電点 gel 中に含 まれる,両性担体の種類及び電極液は、分析目的によって一部变更した手法を用いた。

/ 次元泳動における通電条件について 前報では、経時的に電圧を上昇させる手法を用いたが、今回は

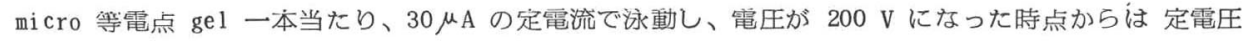
で泳動し、全体で 3 時間通電した。 また、本法に用いる電源装置として、小型・軽量, $\mu \mathrm{A}$ 単位 の定電流出力が可能で、しかも任意の電圧で 自動的に 定電流 $\rightarrow$ 定電圧 に切り替わるものを開発 した。この装置は通常行われている $\mathrm{mA}$ 単位の定電流出力 及び 定電圧出力も可能で、2炊元の micro plate disc 電気泳動法も本装置で兼用して行える。

\section{結 果}

マイマイの各組織等の泳動パターンを比較した結果、成熟した個体の媨からは幼若個体には見られな い pI 4.5 付近, Rm 0.85 以上の蛋白スポット群が存在した。また、ミスジマイマイにおいては、成熟 個体の後触角と脳に、共通した pI $6.5 ， \mathrm{Rm} 0.34$ 〜 0.41 の特徴的なスポットが認められた。

また、新たに開発した電源装置及び泳動槽は、泳動 手法の 精密さと簡略化をもたらし、より良い分析 結果を得るために有效である事が示された。

図

2次元 (micro plate disc) 電気泳動槽 及び 新型電源装置

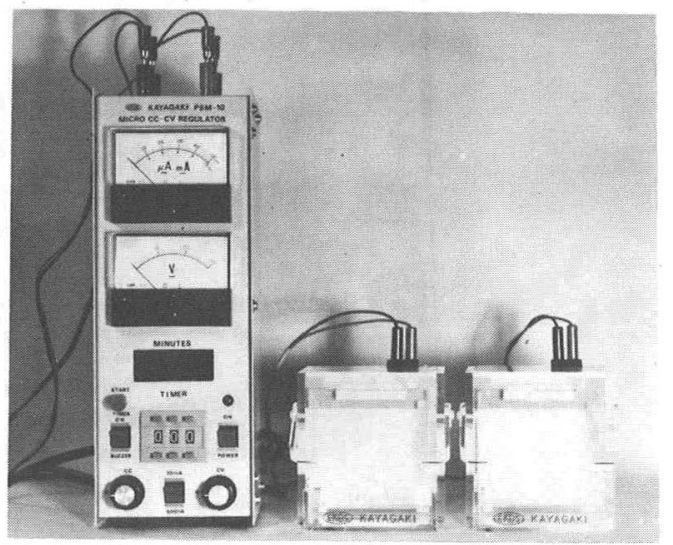




\section{8. ウシ脳組織の Molecular Anatomy \\ ○高橋裕子・真鍋 敬・奥山典生 (都立大·理 ·化学)}

脳組織のMolecular Anatomyを目的として、ウシ脳可溶性タンバク質の分子量、等電点・ 含量を指標とした"Brain Soluble ProteinIndex”の作成を試みた。

( 方法)

ウシ脳の水抽出液叔び、その30-85\%飽和硫安沈殿画分をDEAE - Sephadex A 50 イオン交換クロマトクラフィーKかけて得られた画分を試料とした。

ミクロスケール2 次元電気泳動の装置は、冤士理研作製の OMS 型在用い、マクロスケー ルの装置は自作したるのを用いた。1 次元目は、カラスチンーブ中に作製した 1 M U r e a を含む $4 \%$ ポリアクリルアミトゲルを用いて、等電点電気泳動在行なった。2 次元目は、 4-17\%ポリアクリルアミドラシュエンドダル用い、0.1\% SDSを含むトリスークリ シン bufferで泳動した。染色は、コマシーブルーR-250を用い、さらに、微量のタンハ

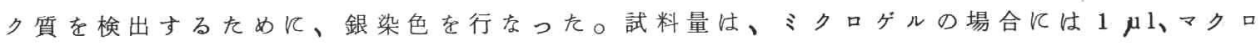
ゲルの場合は、 $50 \mu 1$ とした。

( 結果)

ウシ脳可溶性画分から、等電点 4 加ら 8 の範囲で、ミクロゲルのコマシーブーー染色で 約 200 個、銀染色で約 500 個のタンパク質スボットが検出された。コマシーブー染色し

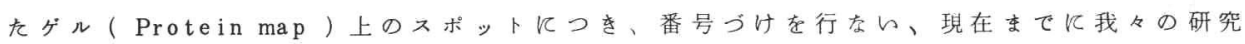

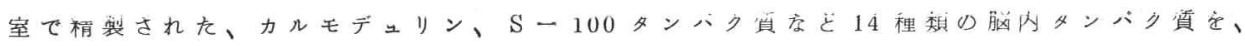
ての map上で同定した。さらに、紐部にわたる解析至するために、脳可溶性画分のイオン 交換クロマトクラフィー粗分画についても、Protein mapを作成し、比較した。

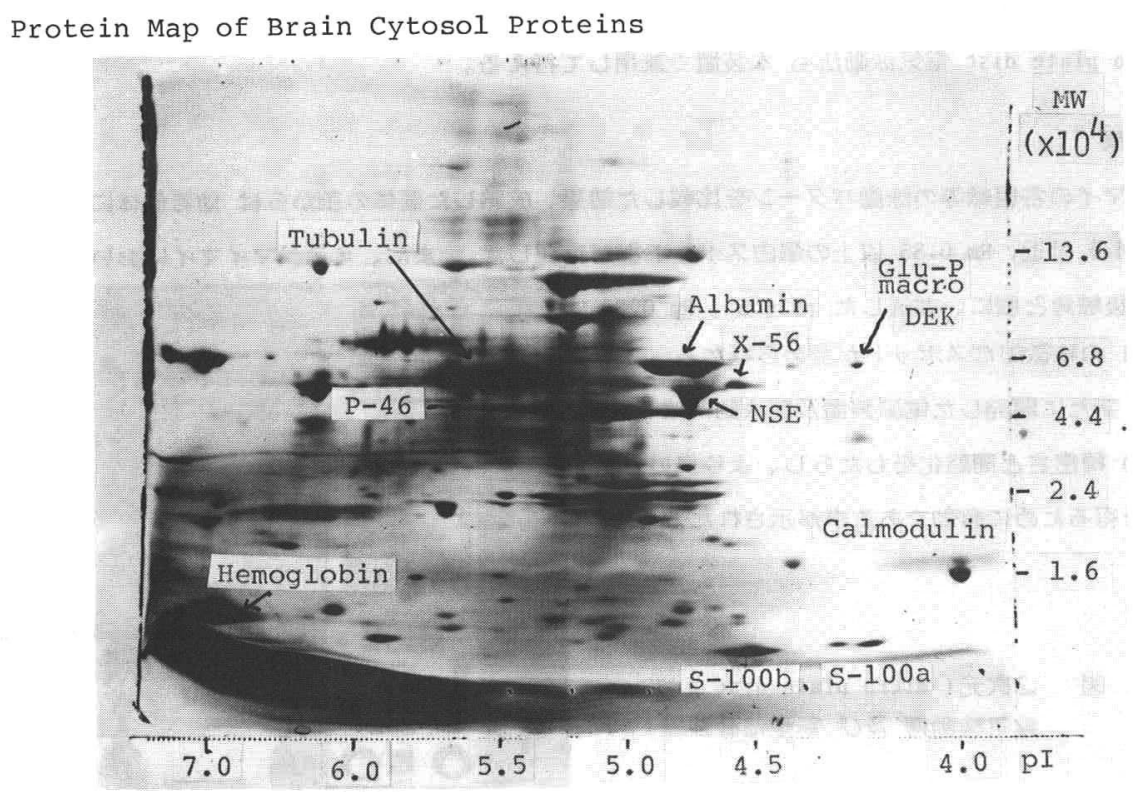




\section{銀染色法による脊髄液中ポリペプチドの検索}

\begin{tabular}{|c|c|c|c|}
\hline $\mathrm{O}$ 平 & 岡 & & 厚 (杏林大·保健 ·生化学) \\
\hline$\equiv$ & 浦 & 勇 & 夫 (杏林大·保健 · 精神衛生) \\
\hline 村 & 尾 & & 修 (杏林大·医·精神神経科) \\
\hline
\end{tabular}

宫永格・服部宗和(国立千葉病院・精神神経科)

我々は, 中枢神経系疾患に和る患者髄液中の蛋白質の泳動バターンと, 疾患の種類や段階との関連を調へ, 治療や 経過判定に役立てるととを目指している。しかし, 通常の電気泳動によりブレアルブミン〜イーグロブリンの範囲の中 に泳動される普通の蛋白質についてはCK 等一部のアインザイム関係を除き, 歴代の研究者によってある程度の知見が得 られている。これに対し，高電圧・短時間の電気泳動によってブレアルプミンょりる陽極側に泳動される微量な蛋白質 やボリへブチドのバンドについては, 髄液ではほとんど手がつけられていない。そとで, 我々は, 杏林大学医学部附属 病院及び国立千葉病院で得られた各種中枢神経系疾患( 分裂病・そうらつ病・脳血栓・䯣膜炎・先天性水頭症等) 患者 の数十の髄液検体を, ミニコンCS-1 5 を用いてほ医血清並みの蛋白質濃度にまで濃樎して, Merck 社バッファーチトリ ソール pH 7.0 (phosphate buffer)及びCorning 社のHFR universal agarose filmb使用する采で, $200 \mathrm{~V} 5$ 分の電気泳 動を行なった後, アガロース電気泳動用銀染色 ${ }^{1) 2}$ とよりブレアルブミン陽極側のバント゚を調べをととろ, relatire

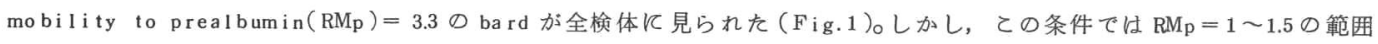
では分離が不充分だったのて，今度は通常蛋白分画用の $\mathrm{pH} 8.6$ バロナール緩衝液を用いて $150 \mathrm{~V} 12$ 分泳動後，同様に銀 染色したとてろ, 前の条件下の $\mathrm{RM}_{\mathrm{p}}=3.3$ の bardは突き好けてしまって検出できなかったが, 新条件下で $\mathrm{RM}=1.2 \sim$ 2.3 の範囲に数本のバンドが見られ，そのパターンは検体によって若干異なっていた（Fig.2）。いずれる, 同じ患者の 血清には全く見られず, 又, 娟液検体の濃縮にミニコンA-25を使用すると消失するとと万から, 分子量 1 2万の高 分子性ボリベブチドと思われる。それらのバンドのパターンによる検体のclassificationを行ない, 疾患の種類・段階 及び通常蛋白分画值・CKアイソザイムのバーン（全検体にal13 types が認められ，又，疾患の状態の悪いととと BB型比が高いととの間には，正の相関関係が見られた。)等との関連性を検討した。

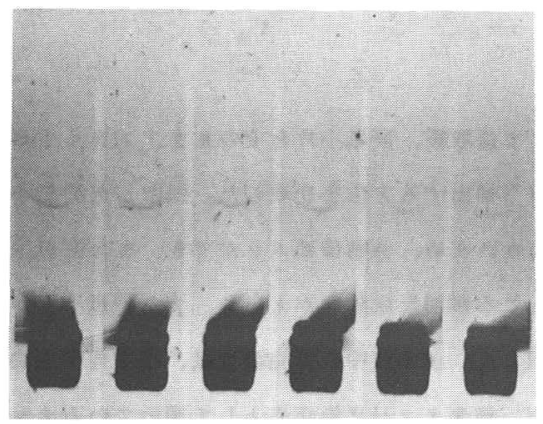

Fig. 1 .

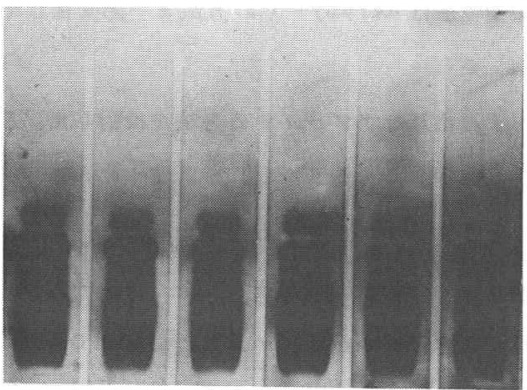

Fig. 2 .

文献

1 ）平風厚他，生物物理化学 $25,201,1981$.

2) Hiraoka, A.et al. Journal of Neuroscience Methods, 5, 221, 1982 


\section{0.アガロース等電点電気泳動法と \\ 銀染色法による歯肉溝浸出液蛋白の分析 \\ ○芝＼cjkstart燁彦・小林久美子・鈴木 洯 \\ 星野 素子・万代 倫嗣・吉田 二良 (昭和大・歯・第 3 補綴) \\ 佐野紀代子 (東京医歯大・医・中検) \\ 中尾＼cjkstart真 (東京医歯大·医・第 1 生化学}

1958 年Bril1 らにより歯肉溝浸出液の存在が報告されて以来、歯槽膿漏と浸出液の関係につんて研究が なされている。歯肉溝漫出液は资症を有する歯肉溝上皮から渗出してくる組織液であり、その量は歯肉の焱症の 進行程度に比例して増加するとして、近年浸出液の量の測定が行われている。しかしながら、1回の採取量が 1 $\mu \ell$ 以下の超微量であるとと、また従来のタンパク染色法では検出不可能であることから、浸出液に含まれる蛋 白成分に関する分析は萎とんどなされていない。炎症程度を知るには、浸出液中の蛋白成分の測定が必要である と思われる。我々は微量蛋白成分の分析後の染色法として銀染色法がすぐれているととをすでに本学会で報告し $\kappa_{0}$

今回、浸出液をアガロース等電点電気泳動で分画し、銀染色法で染色したとてろ、良好な泳動像が得られるこ とがわかったので報告する。

実験材料と方法

浸出液は歯肉と歯の間の歯肉溝に沪紙小片を㨉入し、歯肉溝浸出液を採取した。

浸出液の量は歯肉溝浸出液測定器、ベリオトロン（ HARCO 社）により測定した。

アガロース等電点電気法は $0.5 \%$ ア 持体とし、0.5 M- $\mathrm{NaOH} 0.5 \mathrm{M}-\mathrm{Ac} \mathrm{OH}$ 液を電極液とし、 $6.25 \mathrm{~W} / 1 \mathrm{Pl}$ ate $77^{\circ} \mathrm{C}$ で冷却しつつ60 分泳動 を行った。

銀染色法はKerenyll らの方法を一部改良した我々の方法によった。

結 果

まず浸出液をアプライする方法を検討した。浸出液を沪紙小片で採取後、沪紙小片をそのままアブライする方 法、及び沪紙小片を50 5 l の蒸留水に入れ、一夜浸とらしながら抽出する方法を比較した。採取した沪紙小片 を、そのままアプライすると浸出液が均一に沪紙にしみとんでてないため、泳動像にムラができ、また沪紙巾が $2 m \pi$ と狭いため泳動像がみにくかった。一方抽出液を泳動したととろ鮮明な泳動像がえられ、また沪紙小片から ほ医、タンパクが抜けているととが確認できたので抽出法を採用した。浸出液中の蛋白濃度は、潘血清蛋白濃 度に匹敵するが、1回の採取量が $1 \mu$ 以下の超微量であるため、従来タンパク染色法として用いているクマシ ーブルーR 250 法に上り染色したところ、浸出液中には、2本のバンドしか検出出来なかった。しかしながら 銀染色法に上り染色したととろ PI 4 8.5 立で約 30 本のバンドが検出された。その泳動像は血清タンパク分 画像に類似して、その主たるバンドのPI は 4.5〜 5 でアルブミンに相当するPIであった。デンシトメトリー を行ったとてろPI 4.5〜 5.0 のバンドが約 $50 \%$ の濃度バーセントを占めた。現在各タンパクバンドを Immun of ixation Kょり同定を行っている。 


\section{1. 分離蛋白スポットの高速酵素化染色法 \\ ○䓓迪夫・吉田基子(日立中研)}

二次元電気泳動法 ${ }^{1)}$ を臨床分析分野に応用しょうとする場合，本泳動法の高速化おょび操作性の向上は重要な研究 課題となる。本報告では二次元泳動法により分離された蛋白スボットの新しい高速染色法について述へる。泳動像の 電算機利用による自動定量法, ${ }^{2}$ 高速泳動分離法 ${ }^{8)}$ については以前発表された。

\section{方 法 の 概 要}

本染色法の原理は以下の通りである。すをわち、ボリアクリルアミドゲル上に分離された蛋白にーミンを結合させ， 蛋白をぺルオキシダーゼ活性を有する蛋白に変換し，その酵素活性により過酸化水素存在下で色素前駆体を酸化し蛋 白質分子上に色素を蓄積させ染色スボットを得るるのである。

具体的を実験手順を以下に示す。常法に上り未変性血清蛋白を等電点分離し, 二次元目の分子量分離時に陰極液

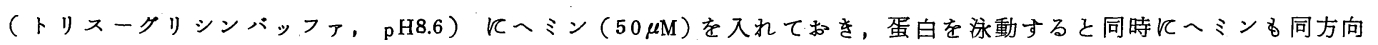
（陽極方向）飞泳動させ蛋白に一ミンを吸着させる。一次元目のゲル内の蛋白が二次元目のゲルに入り終った時点で 陰極液をへミンを含まず KON $(1 \mathrm{mM})$ を含むトリスークリシンバッファに交換し，泳動をつうけ，蛋白の分子量分離 を完結させると同時に蛋白に結合していないバッククランドのへミンを泳動除去する。KONはバックグランドに微量 存在するへミンのペルオキシダーゼ活性を抑制するために添加する。とのように二次元分離されへミンを結合した蛋

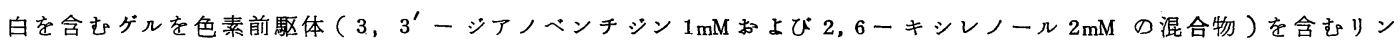

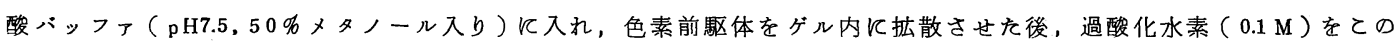
反応液に添加し、スボットを発色させる。

\section{結果および考察}

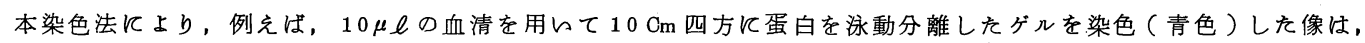
クーマッシーブルーで常法にょり染色した像に近い。染色に要する時間(色素前駆体の払散および過酸化水素にょる 発色に要する時間) は $15 \sim 30$ 分である。発色は色素前駆体の酸化重合によると考えられ, 生成色素は水に不溶となる

本法に上る染色におらてはその過程に関与する因子の数が多いため，現在最適の染色条件が求められてはいない。 本染色法では使用する色素前駆体は特に重要であ。シアミノベンチシン，キシレノール混合物以外の多くの芳香族 アミン,フェノール類, 例えば,メシシン,イソューシェノール,アミノアンチビリン,アミノサリチル酸など、を テストしたが,より良い結果は得られなかった。なお，キシレノール単独ではスボットは染色されず、シアミノベン チシン単独です弱いコントラストしか得られなかつた。

クーマッシーブルー染色法と本法の異なる点の一つは蛋白質の相対染色強度にある。例えば, 本法では1gGの染色 強度は $\alpha_{2}$-HSクリコプロティンの染色強度上り低らが,クーマッシー法ではこの逆になる。へミンに遊離アミノ酸を 配位させた化合物のペルオキシダーゼ活性を測定した結果 $\left.{ }^{4}\right)$ から推論して分子中にヒスチシン，あるいは，アルギニ ン残基を有する蛋白は本染色法で感度良く検出されると思われる。

クーマッシー法では, 通常, 染色, 脱染過程を含めて一夜を要している。銀染色法 ${ }^{5)}$ は感度は高らが, 反応過程が 複雑で，操作性が悪く，長時間を要する。本酵素化染色法はてれら従来法の欠点を補える可能性があると考えさらに 検討して行く。
参 考 文 献
1）真 鍋敬，他：生物物理化学，22:171, 1978 .
2) 伊藤 迪夫, 他：生物物理化学，23:2441979.
3 ) , 真 鍋敬，他：生物物理化学，25:161, 1981 .
4) Tohjo, M. et a l. :Arch, Biochem. Bi ophy, , $99: 222,1962$
5) 0 akley, B. R., et a 1. :Anal. Bi ochem., 105:361, 1980 


\section{2. 等速電気泳動法による血清シアル酸の分離と定量}

○坂 岸 良 克・池 田守(埼玉医大・生化学)

血清シアル酸はシアロタンパクとして正常血清中に常在し, 男性值55７0, 女性 値50〜65 $\mathrm{mg} / d l$ 程度とされている。

糖タンパクが, 炎症性疾患あるいは癌に際して血清中に増量するととは既に多く の人々によって見出されており，すでにC R P， $a_{1}$ - Acid Glycoprotein, Haptoglobin が心筋梗塞の発作後上昇するてとはその診断および治療に利用されている。

シアル酸も $a_{1}$-アンチトリプシンとともに, このような細胞の損傷, 壊死を伴な う疾患時に上昇し，その有用性は近年きわめて注目の的となってきている。

われわれは，アルカリ性ホスファターゼなどの糖タンパク性酵素および細胞表面 におけるシアル酸の役割について検討を続けてきたが, 最近, N A N A ー ルドラ 一ゼ・ピルビン酸オキシーダーゼ（ＰＯＰ）を利用するシアル酸定量法が開発され たので, 従来の方法と新法を比較検討し, 併せて等速泳動による分離とその定量性 をしらへてみた。その結果若干の知見と成績をえたので報告する。

実験方法：正常および各種疾患々者血清について，チオバルビッール酸（T B A ) 法と新法を比較した。後者は極東製薬においてキット化されたもので, 次の原理に よるあのであった。

シアル酸〔結合型〕 ノイラミニダーゼ $\longrightarrow \mathrm{N}$ ーアセチルノイラミン (NANA)

$\mathrm{NANA} \stackrel{\mathrm{NANA} \text { A アルドラーゼ }}{\longrightarrow} \mathrm{N}$ ーアセチルマンノサミントピルビン酸

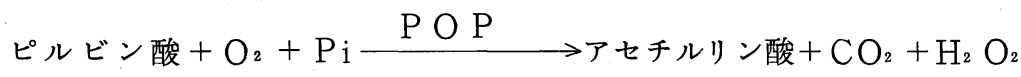

4 ーアミノアンチピリン+EHMT $\stackrel{\mathrm{POD}}{\longrightarrow}$ 赤紫キノイド $(550 \mathrm{~nm})$

こ〉で, P O P はピルビン酸オキシダーゼ, $\mathrm{E} \mathrm{H} \mathrm{M} \mathrm{T} \mathrm{N}$-エチルーN-（ $\beta$ - ヒ ドロキシュチル) - m-トルイジン, P O D ペルオキシダーゼである。

等速電気泳動には各血清をシアリダーゼ処理後島津 I P - 1 B 型によって実施し た。先行液は $5 \mathrm{mMHCl}-5 \mathrm{mM} \beta$-アラニン（ $0.25 \% \mathrm{PVP}$ ), 後続液には $5 \mathrm{mM}$ $\mathrm{n}$ 一カプロン酸を採用した。泳動条件は $15{ }^{\circ} \mathrm{C}, 50 \sim 100 \mu \mathrm{A}$, 約 40 分であった。

実験成績: 血清のノイラミニダーゼ処理時間についてしらべたとてろ，ほぼ 20 時間 のインクベーションが必要であったが， T B A 法の值と等速電気泳動法による值は 良く一致し，いづれあ直線性がすぐれていた。NANA アルドラーゼ， P O P 法は $37^{\circ} \mathrm{C} 20$ 分間で測定でき,迅速ではあるが等速泳動による值より，低目の值を示した。

Zone lengthから求めたシアル酸量は $5 \mu \mathrm{g}$ まで直線性がありWeiland ${ }^{1}$ のシアル酸 そのものの定量の結果では $0.2 \mu \mathrm{g}$ ま゙測定可能とされていたが，等速泳動法による 血清シアル酸の定量に十分利用しうるととが明らかとなった。

1). Weiland, E, Tham, W, Bläker, F. : J . Chromatogr. 214, 156-160 (1981) 


\section{3. 血清蛋白質の細管電気泳動 第 2 報}

○小島清嗣・真鍋 敬・奥山典生 (都立大・理・化)

第 32 回本学会で、LKB 2127 Tachophorを用いた血清タンパク質の細管電気泳動について 報告した。今回は、島津 IP-2A 用いた血清タンハク質の分離てついて報告する。

( 方法)

（1）装置島津 I P-2A（細管一 $-\phi 0.5 \mathrm{~mm} \times 20 \mathrm{~cm}$ のテフロン製、送液はベリスタポンプを用 いた方法) を用い、試料の検出にはUVと電位勾配の両方を用いた。

（2）泳動条件先行液は $0.01 \mathrm{MC} 1$ Kアメシォールを加えて p Hを9.0 としたもの、後続液 は $0.01 \mathrm{M}$ アミノトデン酸一 $0.01 \mathrm{M}$ アメシオール飞水酸化ナトリウムを加えて にしたるのを用いた。先行液にはBrij35を0.1\%(W/V)になるよらに加えた。泳動は 200 $\mu \mathrm{A}$ 定電流を 5 分間、続して $100 \mu \mathrm{A}$ 定電流で行なった。

(3) $\mathrm{pK}$ マーカー $\mathrm{pKa}$ が異なり、 $\mathrm{UV}$ 吸収をるつ低分子量物質（2-チオバルヒタール 酸、バルビタール、ヒボキサンチン、ウラシル、トリプトフォン、フェノール)を、泳動条件 検討のための $\mathrm{pK}$ マーカーとして用いた。

( 結果)

（1）図 1 は、 $\mathrm{pK}$ マーカー混合物 $1 \mu 1$ を一定量のアンホライン（ pH 3.5-10）飞続らて 注入し泳動したとを、最初のピークから最後のピークまでの時間(試料ゾーン巾)を、用いた アンホライン量に対してプロットした結果である。試料ゾーン巾はアンホライン量と比例した。

(2) 後続イオンとして、 $\beta$ - アラニン、GABA、 $\boldsymbol{E}$-アミノカブロン酸、アミノドデカン酸

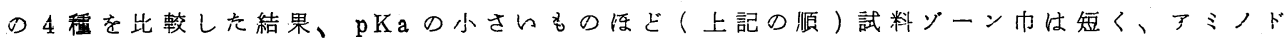
デカン酸を用いた時の試料（ $\mathrm{pK}$ マーカー混合物）の分離が最る良好であった。

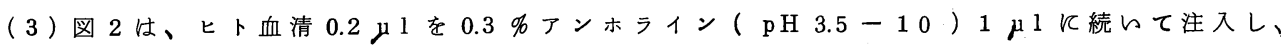
上記条件で泳動した結果でる。精製された血清タンパク質を単独で泳動した結果と比較して、 フルブミンを含む分画、トランスフェリンを含む分画、オークロロプリンを含む分画が同定され た。また、この分離、検出は 20 分以内で終了した。

$$
\text { Fig - I }
$$

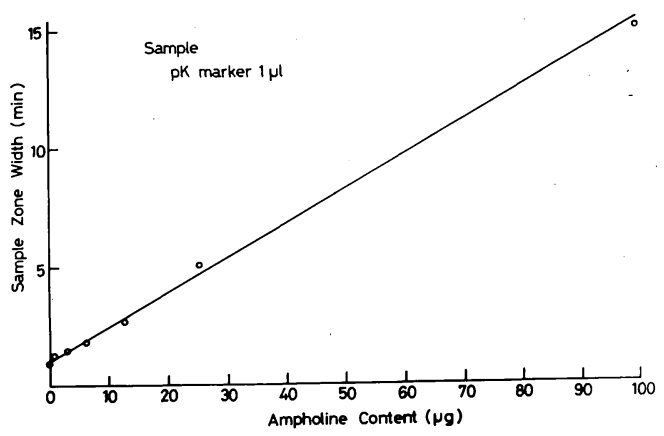

$$
\text { Fig-II }
$$

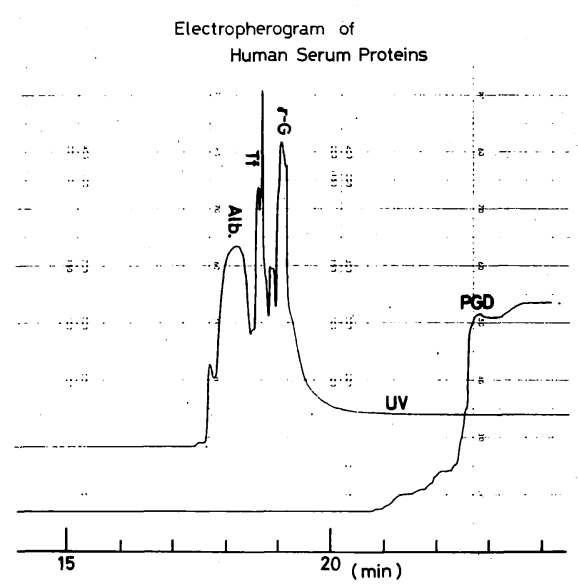




\section{4. 無担体電気泳動の高速化への泳動基碟条件の検討}

○安川 㔨・小島清嗣・真鍋 敬・奥山典生 (都立大·理·化学)

すでに、可溶性タンパク質、膜成分タンパ質についての無担体電気泳動については発 表したが 1）2）3）4）本論文におらては電気泳動の高速化をはかるため電気条件、上り安定 した $\mathrm{pH}$ 勾配を得るため飞電極液の濃度と組み合せ、拡散防止のための添加剤の種類と濃度、 泳動後の送液速度について検討した。

（方法）装置上部電極槽泳動槽（内径 $5 \mathrm{~mm}$ 、外径 $7 \mathrm{~mm}$ 、長さ $145 \mathrm{~mm}$ の゚リエ チレン管）、下部電極槽、冷却槽、支持部より構成される泳動装置および $0.2 \mathrm{~mm}$ チレン等につないだ注射針、ベスタポンプ、フラクションコレクターより成る自動分取 装置を用いた。4)

（結果）電圧条件の検討泳動溶液飞は 2 \% アンフォラインー $0.075 \%$ アガロース、泳 動標品はウシへモグロビン（再結晶）、溶血液、血清などを用んたっprefocusing 時間、 focusing 時間、泳動距離を測定した。アンフォライト組成の検定は、分画、 $\mathrm{pH}$ 測定を 含めて 60 分以内に終了した。電压を高めた ( $1400 \mathrm{~V})$ prefoc u s ing 操作の導入に上り 泳動は 40 分、分画、 $\mathrm{pH}$ 測定を含めて 80 分で終了した。Fig一I p p efocusing 後ウシ へモクロビン（再結晶）を添加し、1400、1200、1000、800、600 Vでのfocusing時間と 移動距離を示した。Fig一II アンフォライン、フォルマライト、バイオライト、セルバィイ ト、フシ $\mathrm{E}$ な゙各社のアンフォライトの $\mathrm{pH}$ 勾配を示した。電極液の検討、2\%アンフォライ ンー $0.075 \%$ アガロ一スを用い $1400 \mathrm{~V} て ゙$ 泳動後通電状態のまま分画後 $\mathrm{pH}$ 測定を行った。電 極液濃度は、水酸化ナトリウム（ $0.1 \mathrm{M} 、 0.04 \mathrm{M})$ 一リン酸（ $0.3 \mathrm{M} 、 0.1 \mathrm{M} 、 0.01 \mathrm{M} ）$ 組み 合せで行い各 $0.1 \mathrm{M}$ の時が、又電極液の組み合せは、陰極液：アメシオール、トリスアミノ メタン、 2 アミノ 2 × ル 1 プロパノール、エチレンシアミン、水酸化ナトリウム、陽極液 ：リン酸で各濃度は $0.1 \mathrm{M}$ を用いトリスアミノメタンーリン酸、 2 アミノ 2 メチル 1 プロパ ノールーリン酸が $\mathrm{pH} 10$ 付近まで良好な $\mathrm{pH}$ 勾配を示した。拡散防止の検討添加剤は U V 吸收がなく、電荷をもたないるのとしてポリエチレングライコール、ポリビニルアルコール、 ハ1ドロキシプロピルメチルセルロース、アカロースの種々の濃度についてウシへモクロビ ン（再結晶）を用い拡がりを測定した。添加剤はアガロースが良く $0.075 \%$ 溶液で 60 分放置 した時 1.36 倍の拡がりを示した。送液速度の検討 $0.075 \%$ アガロース溶液を用いウシへモ グピン (再結晶) 注入後、分速 $0.06 \mathrm{ml} 、 0.17 \mathrm{ml} 、 0.32 \mathrm{ml} 、 0.47 \mathrm{ml} 、 0.62 \mathrm{~m} 1 、 0.86$

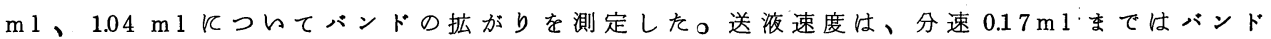
の拡がりは変らずに分速 $0.32 \mathrm{ml}$ 以上で急激に増加した。
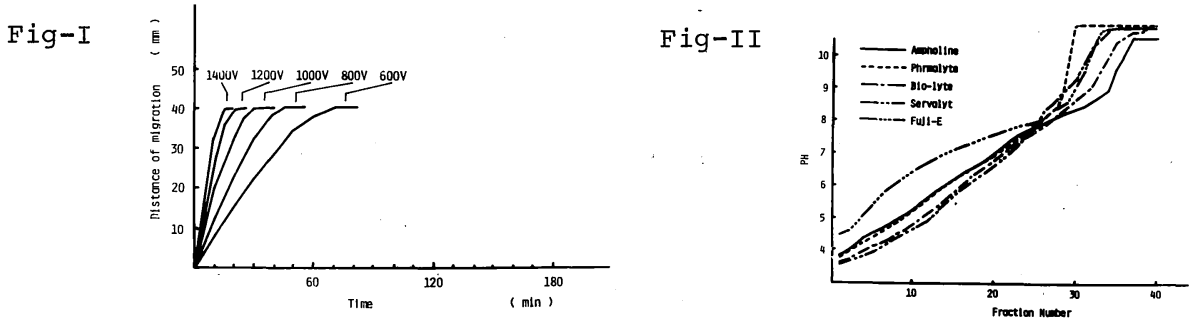

1 ) 小島清嗣, 真鍋敬, 奥山典生：分析化学， $30 ， 26 ，(1981)$

2 ）小島清嗣，真鍋敬，奥山典生：生化学，吕，601，(1980)

3 ) 安川董, 小島清嗣, 真鍋敬, 奥山典生: 生物物理化学。2 $25,196,(1981)$

4 ) 安川董, 小島清嗣, 真鍋敬, 奥山典生：生化学, $53,704,(1981)$ 


\section{5. 泳動装置の規格化と泳動図表の表示について \\ 井上勤 (東京学芸大·生物)}

医学・生物学領域における電気泳動法を用いる研究は年々盛んになり、生化学関係雑誌に登載される method 中最も多いものの一つになった。最近日本では高校生物にも電気泳動法が理科振興法として取り入れられ、 電気泳動活を用いる研究も多くなり、大学入試にも電気泳動図が出題されるようになってきた。しかし、泳動 の結果発表される泳動図あるいはデンシトグラムの表示は研究者によって一定せず、研究者間での比較研究はも とより、医学・生物教育上にも混乱を生ずる原因になっている。 また、電気泳動メーカー側でも機器の表示法 に統一性がないため、各社とも表示がまちまちであり、不特定多数の使用ならびに教育上も不適当である。

高校生物に電気泳動法を導入する場合、これらの混乱を避けるため泳動装置及びその泳動図の表示法について 統一することを提案しそれらが守られている。その提案は、

1 泳動装置には安全装置を取り付けること。( 泳動槽のふたをとった場合、電源が切れる。)

2 整流器には電流計・電圧計を取り付ける。その取付け位置は左側を電流計とし、右側を電圧計とする。 ( 電気の原理から電流計が電圧計より重要である。)

3 Terminal knob の極性は赤を陽極とし黒を陰極とする。ターミナルを左右平行に並べる場合は、左側を 陰極、右側を陽極とする。上下に並べる場合は、上を陽極、下を陰極とする。リード線は赤を陽極、黒 を陰極として使用し、それ以外の色は使用しない。

4 泳動槽は向って左側を陰極とし、右側を陽極とする。

5 泳動図は右側を陰極とし、泳動方向左側を陽極とする。

6 デンシトグラムも右側を陰極、左側を陽極として表示する。 学会に発表される図表の表示は研究者によって一致せず、2 次元電気泳動法が発表された後更に混乱を増し てきた。よって炏の通り表示法を統一することを提案する。

（1）泳動装置・泳動槽は高校提案の通りとする。

（2）泳動図・デンシトグラムの表示は泳動方向を陽極とする。但し電気浸透が強く泳動の大部分が陰極に 向かう場合（セパラックスを用いたセルロースアセテート電気泳動 ）もこの原理に従って表示する。

2 . 等電点電気泳動法の場合、pI の低い方を陰極左側として表示する。

(3) 2 次元電気泳動

1 次元の等電点は $\mathrm{pI}$ の低い方を左側とする。

2 次元は上を陰極とし、泳動方向を陽極とする。

（4）Disc 電気泳動図を表示する場合

a・横に表示する場合は、左側を陰極側とし、右側を陽極とする。

b．縦に表示する場合は、上を陰極とし、下を陽極とする。 


\section{6. ストレプトリジン০の \\ 調製用ゲル等電点電気泳動法による分離の検討 \\ ○鈴木 潤・小林 貞男・吉原 英児 (麻布大 $\cdot$ 環保・生物有機化学 $)$}

支持体を用いて調製用等電点電気泳動法（PIEF）の支持体としては,ポリアクリルアミドゲル (PAG) ,セフア デックス,セフアデックススーパーペビコンC870などが報告されている.しかしPAGは泳動により分離された分 画の抽出に長時間を必要とし，しかも回収率が悪い。一方,セフアデックスは抽出が容易であり,しかもプリント 法により容易に泳動像が確認できる利点があるが, 泳動用ゲルの調製に際して, 一定量の水分を蒸発させる必要 があり,操作が繁雑であることなど一長一短がある.

われわれは等電点電気泳動用アガロースを用いて薄層等電点電気泳動法について種々検討を行い,アガロース

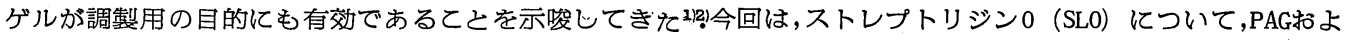
び等䉙点電気泳動用アガロースを支持体としてPIEFの比較を行ったので報告する．

方法

1）支持体一厚さ $2 m m$ ガラス板上に $140 \times 210 \times 5 m m$ の各種ゲルを作成し,Ampholine（pH3.5- $10: \mathrm{pH} 5-8=2: 1)$ はすべて終濃度1.5\%になるように加えて、a）7\%PAG（光重合）b） $2 \%$ アガロースHSIF（Litex） c) 1\%アガロ 一スIEF (Pharmacia)，アガロースゲルは室温でー夜湿潤箱中に放置して使用して.

2）試料一 $1 \mathrm{~m}$ SLO, LotFB6 $\left(4.47 \times 10^{4} \quad \mathrm{HD}_{5} 0 / \mathrm{m} \ell\right)$ を $8 \times 120 \mathrm{~mm}$ ガラス繊維ら紙（東洋GA200）に浸み込ませたの ち,ゲルプレート中央に置き泳動開始14-15時間後に試料片を取り除いた.

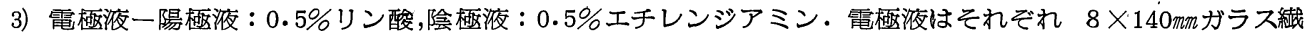
維ろ紙に浸み込ませてゲル両端に置いて。

4）泳動ーゲルプレートは 100 Cの冷却水を循環させで冷却板上に置き,200V, 15-18時間泳動を行って。

5) $\mathrm{pH}$ 測定一前報に従った $\overbrace{}^{3)}$.

6) 抽出扔よび溶血力価の測定一泳動終了後,通電方向に沿って幅3mm間隔にゲルを切離し,各ゲル片は $3 m \ell 0.1$ \%BSA加PBSで一夜抽出,この操作を 3 回繰返して．各分画抽出液は前報と同様の方法で溶血力価を測定して4)。

結果

200V, 15-18時間泳動後の各ゲルのpH勾配をみると,PAGはもっとも急勾配を示し,アガロースIEFはもっとも緩 やかな勾配を示していた．まてアガロースHSIFは両者の中間のpH勾配が得られた．してがってアガロースIEF ではゲル全長の70\%の範囲にわてって溶血活性が認められるのに反し,PAGでは溶血活性の認められる範囲はゲ ル全長の40\%にすぎないが,アガロースHSIFでは両ゲルの中間の範团（60\%）に活性が認められた。このよらに アガロースIEFでは単位pH当りの分離能が他のゲルに比しすぐれていることが判明して。

また，SLOのpIは接近しているてめ,分画抽出液の溶血力価のみからその分離状態を判断することはできない.

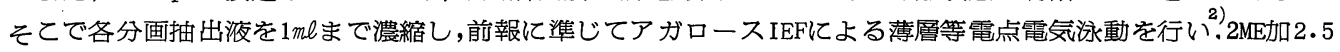
\%ウサギ赤血球寒天重層法により,直接溶血像の測定を行った。その結果,PAGの各分画では分離不良が全域で見

られるのに対して,アガロースゲルではいずれも $\mathrm{pH} 6.0-6.5$ 以下の低 $\mathrm{pH}$ 領域の分離が不良であって .

この原因として泳動時間の不足, 試料のオーバーロードなどが考えられるところから, 負荷タンパク量を半減 し,200V, 15時間泳動後さらに300V, 4時間泳動を行ったて．その結果PAG犯よびアガロースHSIFでは pH5.0- 7.0領域 に複数の溶血帯を示す分画もあってが, 高pH領域の分離は比較的良好で汤った。一方,アガロースIEFでは pH5.0 付近に分離不良域が認められてが,全般的にすぐれた分離を示して。最終的に得られて単一溶血分画は, Agarose IEFで8分画,HSIFで5,PAGで1分画であった．以前に行って調製用セフアデックスゲル等笛点電気泳動 ${ }^{4}(\mathrm{Ampho1i}$ ne Electrofocusing Kit,LKB) によっては1分画のみであった。

以上のことから,SL0のPIEFに打ける,各種支持体の分離能は薄層の場合と同様に,アガロースIEFに優位性があ るここが再認された．アガロースゲルは化学的に不活性で, しかもゲル調製が簡便であり,さらに泳動後のゲル から分離成分の抽出も容易で, かつ回収率も高く,加えてプリント法により泳動状態を確認できるなど, 多くの利 点安有する・してがって, 調製用ゲル等電点電気泳動法の支持体としてアガロースIEFは優れていると考えられる.

文献 1) 小林貞男他: 生物吻理化学, $24: 45,1980.22)$ 鈴木 潤他 : 生物物理化学, $25: 49,1981$. 3）鈴木 潤他：生物物理化学, $22: 207,1979.4$ 4) 鈴木 潤他：生物物理化学, $21: 97,1977$. 


\section{7. ヒト血漿中 tripeptide aminopeptidase $の$ 部分精製と酵素学的検討 \\ ○神田 進司・須藤加代子・菅野 剛史 (浜松医大・検査部)}

我々はすでr.Leucine Dehydrogenase（Leu DH）を共役させたアミノペプチダーゼの定量的ザイモグラムの

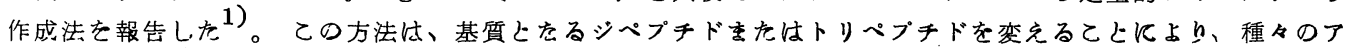
ミノペプチダーゼ活性を染色でをるこにに特徵がある。これらペプチダーゼのスクりーニングを行なら過程で 我々は、血清中のTripeptide Aminopeptidase（EC. 3.4.11.4、以下 TAPに略す）の変動に注目した。そ してて、TAFの持つ病態解折上の意義を明らかにするために、同酵素をヒト血槳より部分精製しその性質を検索 L.た。

〔材料およで方法〕

TAF活性は、、L-leucylglycylglycine（IGG）を基質とし、遊離したLーleucineをLeu DHの共役下KNADHの

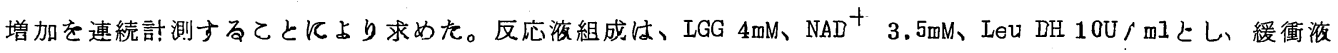

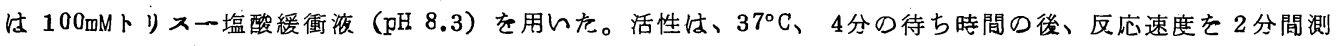
定し、国際単位にて表わした。

L-leucinamide水解活性は杉山らの方法 ${ }^{2}$ ） K、L-leucine-p-nitroanilide 水解活性はSzaszの方法 ${ }^{3)}$

に準じて求めた。

蛋白量の定量はLLwry の方法 ${ }^{4)}$ Kて求めた。標準蛋白には BSAを用いた。

$\mathrm{DEAE}$ 一ルロース カラムクロマトグラフイは、25 x $280 \mathrm{~mm}$ のカラムを用い、0ー0.18M NaC1（1000m1）

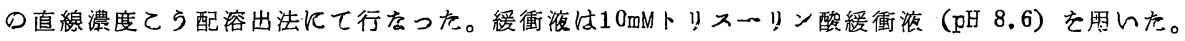

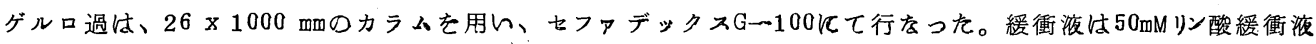
(pH 7.0) を用いた。

等電点分画怟、LKP8100 用いてアンホライン（pH4-6）のショ糖濃度乙う配法にて行なった。

〔結果および考察〕

1. 酵素の精製：精製過程をTable 1 K示した。

2. 酵素の物理的性質: ヒト血獎中の TAFは、セロゲル電気泳動にてpreß位に易動度を持ち、等電点は pH5.0 〜 5.1であった。分子量は、セファデックスG-75Kょるゲルロ過にて約50000と求められ、LAP、Ary1一 amidase、CAPには区別される酵素である。

3. 酵素学的性質: 基質特異性におんて本酵素は特徵があり、トリペプチドである LGGを水解するが、L一leu一 cinamide、L-leucine-pーnitroanilide は水解したん。阻害剂に対する態度もEDTAKょり阻害されず、一

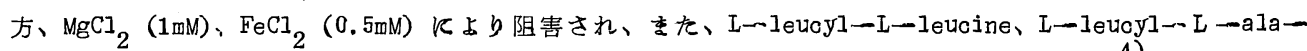

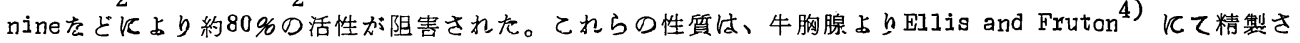
れたAminopeptidaseとよく類似している。また、これまでアミノペプチダーゼ活性测定法に用いられてをた 基質を分解せず、この酵素活性の測定が新しい臨床的意義を持つ可能性怡充分にむる。

〔文献〕

1）神田進司他：生物物理化学、25：167、1981.2) 杉山正康他：臨床化学、9：313、1980. 3) Szasz, G.： Am. J. Clin. Path. $47: 607,1967,4)$ Lowry, O. H. et al. : J. Biol. Chem. $193: 265,1951$.

Table 1. Summary of the purification procedure for tripeptide aminopeptidase from human plasma.

\begin{tabular}{lccccc}
\hline & $\begin{array}{c}\text { Totat protein } \\
(\mathrm{mg})\end{array}$ & $\begin{array}{c}\text { Total activity } \\
(\mathrm{mU})\end{array}$ & $\begin{array}{c}\text { Specific Yield } \\
\text { activity }\end{array}$ & $\begin{array}{c}\text { Purification } \\
\text { factor }\end{array}$ \\
\hline Original plasma & 1454 & 1520 & 1.0 & 100 & 1 \\
$\begin{array}{l}\text { Ammoniumsulfate fractionation } \\
\quad(33 \%-60 \%)\end{array}$ & 169 & 1061 & 6.2 & 70 & 6 \\
$\begin{array}{l}\text { DEAE-cellulose column chromatography } \\
\text { Ge? filtration on Sephadex G-100 }\end{array}$ & 16.5 & 543 & 32.9 & 36 & 32 \\
Isoelectroseparation & 2.8 & 312 & 111.4 & 22 & 107 \\
\end{tabular}




\section{8. n-butanol あるいは Triton X-100を用いた \\ ウサギ骨 ALP の 抽 出 \\ ○山 本 昭 夫・荒 木 万 嘉(兵庫衛研)}

ウサギ大をい骨からの, ALP 抽出を検討した結果, $\mathrm{n}$-butanolを用いる方法と, TritonX-100を用いる方法で,をわめ て高い抽出率が得られたので，その結果を報告する。

材料並びに方法

骨：ウサギ大たい骨骨幹部を骨髄を除いた後，磁製乳鉢で蒸留水を加え，眯濁液になるまで磨砕した。

$\mathrm{ALP}$ 活性の測定：渡辺らの Kind-King 変法を, 基質濃度 $3 \times 10^{-2} \mathrm{MK}$ 変更し, $\mathrm{MgC}_{12}$ を $\mathrm{mM}$ 濃度に添加して行なった。

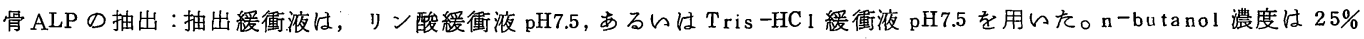
(v/v)で，40分間かくはんした。Triton X-100濃度は $1 \%$ で，40 分間かくはんした。抽出後 $105000 \mathrm{G} 60$ 分間遠心し， 水層を抽出液とした。

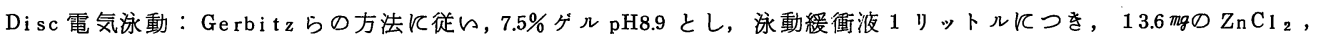

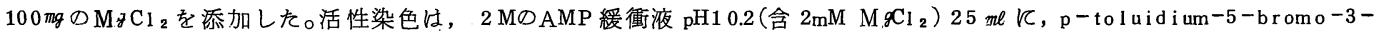
indolyl phosphate 50 mg 加え反応基質液とした。

阻害試験：飯野らの方法に従った。

結果

1） n-butanol 抽出の結果, Tris 緩衝液で, 最高 $17 \%$ の抽出率しか得られなかったが,リン酸緩衝液では, 最高 $93 \%$ の抽出率が得られた。

2） Triton X-100 抽出の結果,リン酸緩衝液では，n-butanol抽出の場合とほとんど変らず，最高 $103 \%$ の抽出率であ った。一方, Tris 緩衝液での抽出率が向上し,最高 $88 \%$ つ抽出率を得た。

3） Disc 電気泳動の結果, n-butanol抽出では,泳動される単一の活性バンドが見られたが, Triton X-100抽出で

は，原点位にも活性バンドが見られた。

4） 56 C 10 分間の熱阻害率は約 80\%で，熱感性を示した。 $5 \mathrm{mM} \mathrm{L}$ - phenylalanine 阻害率は 40〜45\%で，やや抵抗性 を示した。 $3 \mathrm{M}$ 尿素阻害率では, $\mathrm{n}-\mathrm{butanol}$ 抽出とTriton X-100 抽出で異なり，前者では約 $55 \%$ とやや抵抗性を示し， 後者では約 $70 \%$ とやや感性を示した。

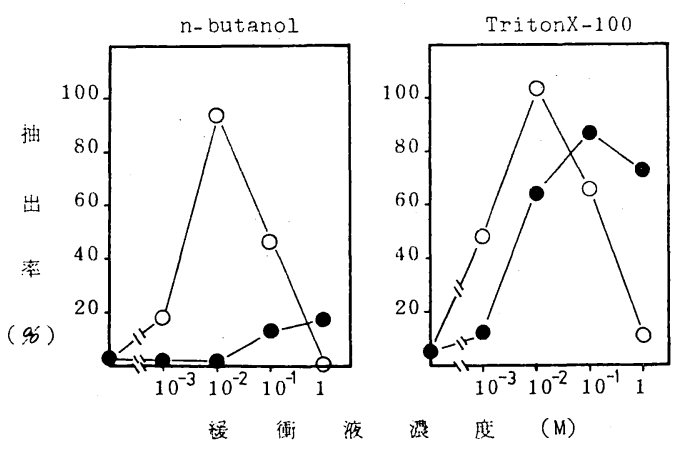

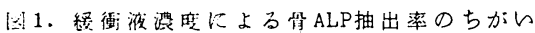
$\mathrm{O}$ - $\mathrm{O}$ リン酸褯衝液 $\mathrm{pH} 7.5$ -— Tris-HCl楥衝液 $\mathrm{pH} 7.5$

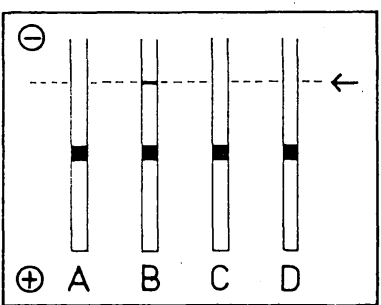

《2. カALPのザイモグラム

A : n-butanol抽出 B : TritonX-100抽出

C : 泳動前にB $\mathrm{B}$-butanol処理

D：泳動前にAKTritonX-100を 198 掼度に添加 


\section{9. 高分子LDH失活因子の解析 \\ ○奥山恵理子・黒宮 洧・長谷部 保・柴田 磐夫 \\ (聖隷浜松病院・中検)}

伊藤 祐子・須藤加代子・菅野 剛央 (浜松医大・検查部)

当院の職員検診におらて, 表 1 K示すようKGOT, GPT, その他の生化学データすすべて正常であるが, LDH 活性の みが $25 \mathrm{IU}$ と異常低值を示す健診者 $(\mathrm{K} . \mathrm{H})$ が存在した。この異常低 LDH 活性の原因につ々て検索したので報告する。

【方法】

1）LDHの活性測定はヘーリンガー社の方法で，LKB 8600 を用いて測定した。

2）LDH I sozyme 分析はセロダル膜を支持体とする塩谷らの方法に拠った。1)

3）混合試験仕 2 種の血清を等量混和し, 室温に一定時間保存後, それぞれの活性值と混合血清の活性値を比較した。

4) ゲル沪過仗 Sephadex G-200を用いた。

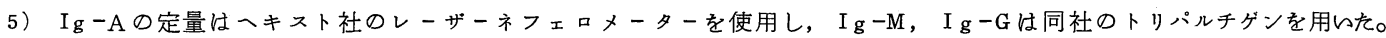

\section{【結果及び考察】}

1）赤血球溶血液の LDH I sozyme 分析の結果，H／M比は $2.9($ normal range = 2.3〜3.5) であり，サブュニットの遺伝 的欠損は否定された。

2）|異常低 LDH 活性の原因解析のため検診の 20 日後に再採血を行い，その直後より LDHの経時的変化をおってみると 血清分離後 48 時間で $48 \%$ の活性となり, 正常対照に比し異常な失活が認められた。

3） K. H 血清と正常血清を用い，I . II 型 $\mathrm{LDH}$ 上昇，V 型 $\mathrm{LDH}$ 上昇等の血清に対して混合試験を行ったとてろ, 残存活 性は 68 ～84\% と正常 control(92〜104\%)飞比し，LDHの失活が認められた。

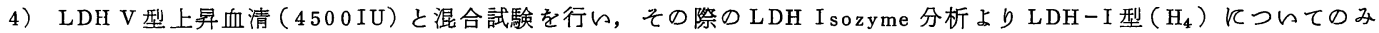

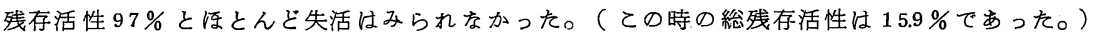

したがって，Mサブニニット選択性の失活因子であるととが推定された。

5）透析実験に上り，透析内液中に失活因子の存在が認められた。とのととから，K．H血清中に存在する失活因子は 高分子であるととが判明した。

6) ゲル沪過を行い，その各分画において混合試験及び I g-A，I g-M，I g-Gの定量を行った結果, 図 1 と示すどとく I g-Aのビークと失活因子のビークが一致した。すえに, K.H 血清中における失活因子は Ig-Aであるととが強く示唆された。 【結【語】

健捸診断の受診者におらて観察された異常低 LDH 活性の原因は，Ig-A と同様の分子量をるつ高分子の失活因子の存

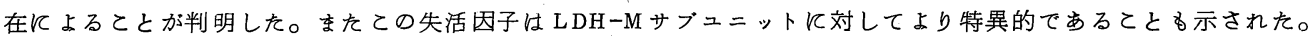

\section{【文献】}

1）塩谷実枝子 他 臨床病理, $19,469,1971$

<表 $1>$ Laboratory data

\begin{tabular}{|c|c|c|c|}
\hline & K.H serum & normal range & unit \\
\hline Alp. & 4.3 & $2.7 \sim 10$ & KAU \\
\hline GOT & 11 & -24 & IU \\
\hline GPT & 6 & -24 & IU \\
\hline$\gamma$-GTP & 5 & -40 & IU \\
\hline LDH & 25 & $150-400$ & IU \\
\hline Т.CHO & 151 & $130 \sim 250$ & $\mathrm{mg} / \mathrm{dl}$ \\
\hline mix test & 10.9 & $92-104$ & $\mid \begin{array}{c}\text { residual } \\
\%\end{array}$ \\
\hline
\end{tabular}

$<$ 図 $1>$ Gell filtration analysis of inhibitory factor

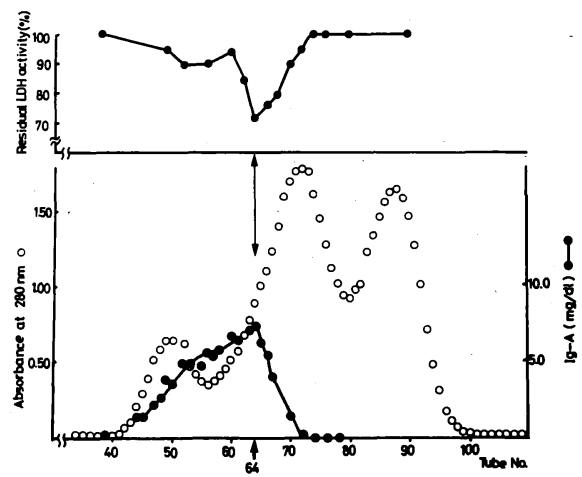




\section{0. 白血 球 の LDH isozyme (第 1 報) \\ ○今泉 忠芳・堀口 正晴 (東京慈恵医大・第 3 分院・内科)}

白血球の L D H isozyme を検討した。血液、気管支肺胞洗浄液 B A L、胸水、膿より白血球を分離し、それらの L D H isozyme，を比較した。

材料と方法 :

白血球の分離：血液：正中静脈上り6〜8ml採血し、ヘパリン添加後 separate L (武藤薬品) 飞重層、2000

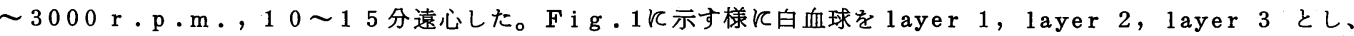
これらを別々に採取した。1 ayer 3 の生理食塩水浮遊液は赤血球が混入するため。比重液（sodium metrizoate solution $32.8 \% \mathrm{w} / \mathrm{v} 2$ 容と separate L 3 容との混液)飞重層し、同様遠心して比重液の上層の白血球層 を採取した。これらは生理食塩水で洗净後、凍結、融解して、これを Sample とした。同一人ょり異る日に採取し た Sampleをそれぞれ1otA、10t Bとした。

B A L 、胸水、膿より遠心分離により白血球層を得、同様飞処理し $S$ ample とした。

B A L の Samp le 、B A L 1 は気管支拡張症、B A L 2 は気管支拡張症、B A L 3 は肺癌の患者から得られた。 胸水は結核性胸膜炎 $(P F)$ 、膿は肺化膿症の患者から得られたもの（pus）を用いた。

L D H isozyme : P A ジェルプレート（栄研）を用い、200volt $20 \mathrm{~mA}$ で泳動した。緩衝液はべロナー ル楥衝液。PH 8 。6, 強度 0.06 を用いた。泳動終了後 L D H染色を行った。

Sample 凍結前飞smear を作成し、メタノール固定、ギムザ染色を施し、鏡見にて観察した。

結果：結果はTable1 1 亿示した。 1 ayer 1 は主にsmall lymphocyteがみられ、LDH isozyme では L D H ${ }_{2} \mathrm{LDH}_{3}$ が比較的高いことがみられた。1 a yer 3 は主に granulocyte,こわれた ce11 がみられ。 lot A では1 ayer 1 と同様な分画像がみられたが、1 ot Bでは、10tA の layer 1 と異り、LDH 5 Kや〉高值が みられた。 BAL 2，BAL 3 はgranulocyteから成り。何れもpus corpscle の分画像と同様飞、 LDH

$\mathrm{LDH}_{2}<\mathrm{LDH}_{3}<\mathrm{LDH}_{4}<\mathrm{LDH}_{5}$ の分画像がみられた。 lymphocyte が主体のPFでは $\mathrm{LDH}_{3}$ の高い分 画像を示した。macrophage が主体のBAL 1 ではBAL $2 、 B A L 3$ と対照的飞 $\mathrm{LDH}_{1}$ の高いB優位の分画像が得 られた。考察：granulocyteを主体とする layer 3 では lot A と lot Bで相違がみられ、これらは又 BAL 2 、 BAL 3 とも異っている。Sample 中のgranulocyteの populationや cel1のこわれ方によって相違が生じてく るのか、functionkよって分画像に変化を生じているのか、決定しがたい。granulocyte を同一の均一のSample として採取することについて、今後検討を要すると思われる。主に lymphoc y te から成る Sampleでは、今回実験 の条件ではSample の間の分画像に著明な相違はない様に思われる。alveolar macrophageから成る B AL 1 は。 granulocyte から成る BAL 2、3と全く反対の傾向をもつ分画像を示したことは興味梁い。要約：白血球の LDH isozyme 分画について検討を行った。granulocyte を含をSampleでは一定の傾向の分画像は得られなかったが lymphocyteを含むSample では大略 $\mathrm{LDH}_{3}$ の高い分画像がみられた。macrophage を含む Sample ではB 優 位の分画像を示した。

Table 1 LDH isozyme of white blood cell

Samples LDH1 LDH2 LDH3 LDH4 LDH5 Smear(main)

lotA layer $1 \quad 13.2 \quad 24.3 \quad 32.9 \quad 21.4 \quad 8.2$ lymphocyte $\begin{array}{llllllll}\text { layer } 2 & 8.6 & 22.4 & 34.5 & 20.7 & 13.8 & \text { lymphocyte }\end{array}$ $\begin{array}{lllllll}\text { layer } 3 & 9.8 & 26.8 & 31.7 & 22.0 & 9.8 & \text { granulocyte }\end{array}$ lotB layer $1 \quad 8.4 \quad 28.5 \quad 39.2 \quad 21.0 \quad 2.8$ lymphocyte $\begin{array}{llllll}\text { layer } 3 & 10.8 & 27.7 & 21.5 & 15.4 & 24.6 \\ \text { granulocyte }\end{array}$ BAL BAL $1 \quad 30.3$ 25.3 $21.3 \quad 13.3 \quad 9.6$ macrophage $\begin{array}{lllllll}\text { BAL } 2 & 5.2 & 13.1 & 14.1 & 15.2 & 52.4 & \text { granulocyte }\end{array}$ $\begin{array}{llrllll}\text { BAL } 3 & 2.0 & 4.1 & 12.2 & 20.4 & 61.2 & \text { granulocyte }\end{array}$ $\mathrm{PF}$ pus 30.2 21.1 36.3 12.1 0.3 1ymphocyte $4.6 \quad 6.413 .815 .659 .6$ pus corpscle number of isozyme:\%

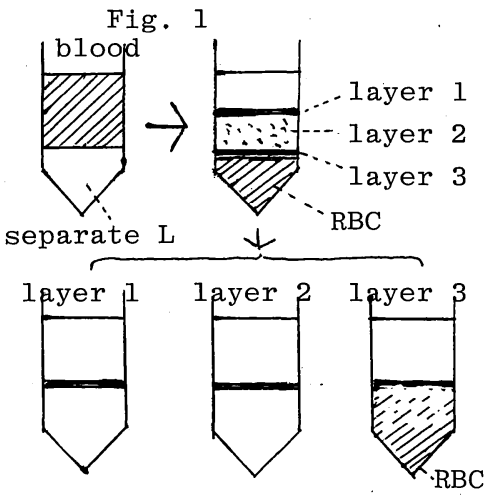




\title{
31. グリセリン含有アガロースゲル等電点電気泳動法による
}

\author{
人組織中 LDH isoenzyme の分離について \\ ○唐下 博子・一村 光子 (岡山大·臨檢技師学校) \\ 馬場 三和・馬場 巽 (岡山大·医 $\cdot$ 中検)
}

第 32 回電気泳動学会総会において, 私達はフガロースゲルにグリセロール（メルク社）を $40 \%$ に添加し，等 電点電気泳動中に生ずる L D H 酵素活性の失活を防ぎ, 安定した分離パターンを得ることを発表した。今回, さら に人組織中の L D H i soenzyme の分離条件について検討を行い，良好な成績が得られたので報告する。

\section{〔実䲗方法〕}

(1)等電点電気泳動用アガロースゲルの作製 $\quad 40 \%$ グリセール含有 $1.08 \%$ アガロースゲル ( Marine

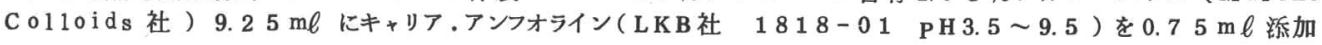
L, mould 中で, $0.5 \mathrm{~mm}$ 厚のゲルガラス板を作製する。

(2)組織抽出液人組織は, 冷 ${ }^{1} / 15 \mathrm{M} \quad \mathrm{PBS}(\mathrm{PH}=7.2)$ で, $3,000 \mathrm{r} . \mathrm{p} . \mathrm{m} .30$ 分ずっ3回( 久保 田冷凍遠心器 $\mathrm{KR}-200 \mathrm{FA}$ ) 洗浄後, 組織片 $100 \mathrm{mg} / 250 \mu \ell{ }^{1} / 15 \mathrm{M}$ PB S 水水中でホモジナイズする。 ホモジナイズした組織液を1 1,000 r.p.m.2 分間（Eppendorf centrifuge 3200 ) 遠心分離する。

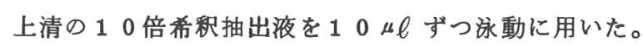

(3)電極液陽極側は, $0.025 \mathrm{M} \mathrm{L}$ - クルタミン酸 $40 \%$ グリセリン溶液, 陰極側は $0.5 \mathrm{M} \mathrm{N} \mathrm{N}_{2} \mathrm{OH}$, $0.025 \mathrm{M} \mathrm{Lーリシン} 40 \%$ グリセリン溶液を用いた。

(4)通電条件自家製等電点電気泳動用白金線電極 $(0.7 \mathrm{~mm} \varnothing)$ を用い, $2{ }^{\circ} \mathrm{C}$ 冷却下で, 定電圧 $200 \mathrm{v}$ 10 分, $500 \mathrm{~V} 180$ 分, $750 \mathrm{~V} 60$ 分, $900 \mathrm{v} 15$ 分間通電を行った。

(5) L D H 泳動終了後, ゲル面に，人アルブミン溶液 $(7.8 \%)$ を $200 \mu \ell$ 塗り拡げ， 2 分間室

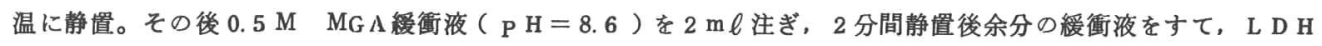
醭素基質溶液（ヤトロン社， $\mathrm{LDH} \cdot \mathrm{L}$ キット）を $6.0 \mathrm{ml}$ かけ， $37{ }^{\circ} \mathrm{C} \quad 30$ 分間反応後， $3 \%$ 酢酸溶液中で 15 分間反応停止, 水洗 45 分間。乾燥。

〔結果〕

図(1)は各組織の等電点電気泳動分離パターンを示し, 図(2)は肝臟抽出液の通常の電気泳動法での分離バンドであ る。困(1)に示す様に, 泳動終了後ゲル面に人アルブミン溶液を均等に spread することにより，LDH 5 の位置 の分離パターンが非常に鮮明となり, 各臟器中の L D H i soenzyme を明瞭に判別することが出来た。

図(1)人組織中 L D H i soenzyme（IEF図）

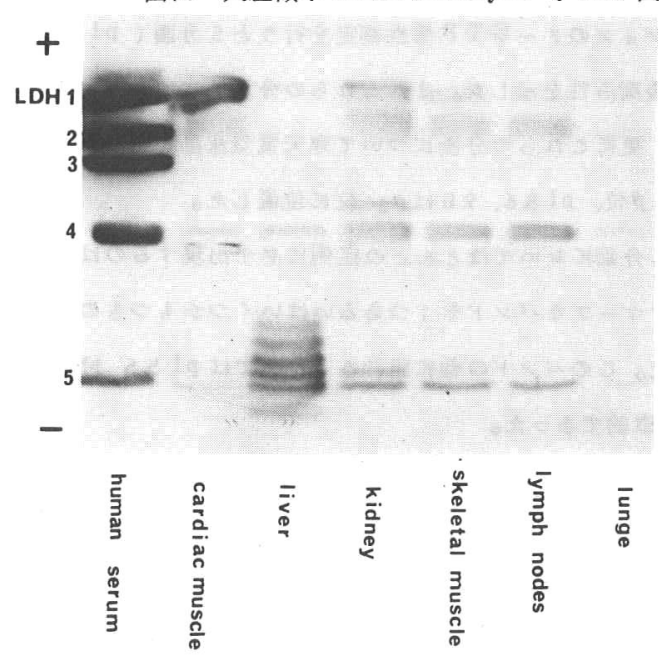

図(2) EF 図

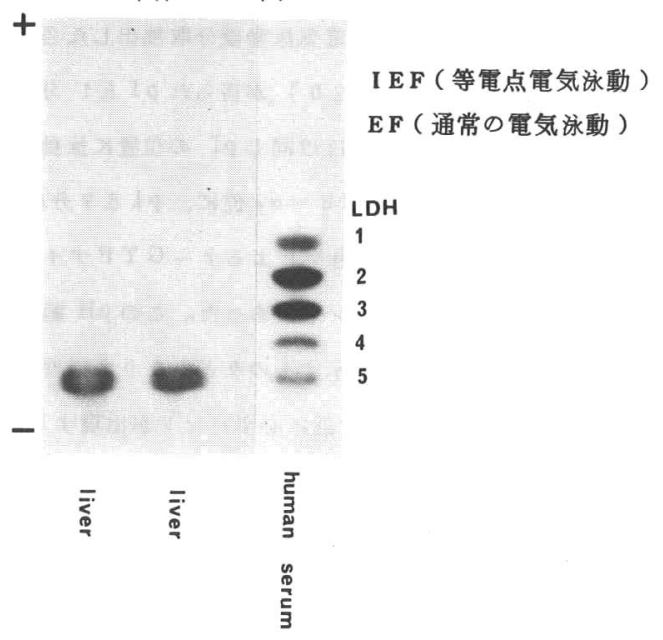




\section{2. 等電点電気泳動による血清 $\gamma$-GTP アイソザイム分析 \\ ○長裕子・佐野紀代子 (東京医歯大·医・中検) \\ 中尾真 (東京医歯大·医・第 1 生化学)}

我々は、支持体沉アガロースを用いた等電点電気泳動に関して、再現性の良いパターンを得るための諸条件を 検討し、良好な泳動像が得られる方法を考案した。更に本法を用いた䣼素アインザイム分析への応用を試みてい る。 $r$ - G T P は硫安固定後、醭素染色を行えば鮮明な泳動像が得られることがわかった。また各アインザイム 分画つ諸性質を確かめるをめセファテックスを用いたブレパラティブ等電点電気泳動法に上り、各バンドを再現 性良く分取するととを可能とし、これらの件て関してすでに本学会で報告した。

我々は $r$ - G T Pアイソザイムム分析法として今迄寒天電気泳動に上る方法と等電点電気泳動沉よる方法を開発

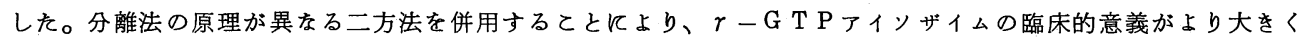

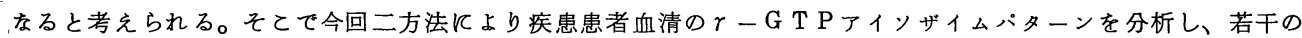
知見を得たので報告する。

方法

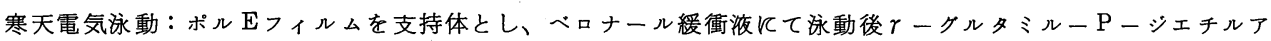
ミドアニリドを基質として醭素反応させ、 $\alpha$ ーナフトール、過ヨウ素酸とで発色させる我々の方法 ${ }^{1)}$ を用いた。 アガロース等電点電気泳動：0.5\%アガロース I E Fを支持体とし、0. 5 M唒酸、0.5 M水酸化ナトリウムを 電極液とし、1ブレート当り $6.25 \mathrm{~W}$ の条件（最大電圧 $1,500 \mathrm{~V}$ 、最大電流 $20 \mathrm{~mA}$ ) 下で泳動後 $50 \%$ 硫酸 アンモニウムで30 分固定した。酵素染色は寒天電気泳動法と同様に我々の方法を用いた。

プレパラティブ等電点電気泳動：アンホラインを約 $2 . \%$ 含をセファデックス I E F を支持体とし、0.1 M リン

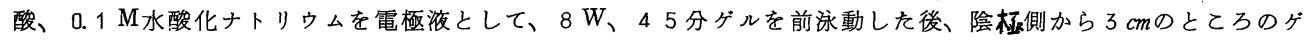
ルをかをとり、血清と混じて再びダル層ともどし、30W、4 時間泳動を行った。泳動終了後 $0.7 \mathrm{~cm}$ 巾にゲルを 分取し、0.2 M塩化ナトリウムで抽出を行った。

結 果

プレパラティブ等電点電気泳動後分取抽出した各フラクションのrーG T P 活性測定を行らと 5 分画（ $\mathrm{pI}$

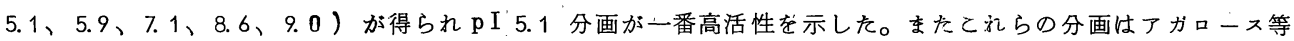
電点電気泳動にいても深同じ $\mathrm{pI}$ の位置に泳動された。更にてれらの分画について寒天電気泳動を行ったと

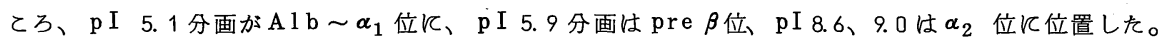
アガロース等電点電気泳動によるrーG T P アインザイム分画において医とんどの症例に必ず出現するのは pI 4.5 ～ 5 の間飞あるバンドであった。ての $\mathrm{pH}$ 範囲内でシャーブなバンドを1つあるいばいくつかるつるの、 あるいは仏いバンドを示するのなどかる多様性を示した。てのバンドの他に胆汁らっ滞例では pI 5.5 付近、 悪性厓瘍例で p I 6.5 付近飞必ずバンドが出現するのが特徽的であった。

文 献

1) 佐野紀代子、長裕子：臨床検查、20：953、1980。 


\section{3. “CK-MM”より陰柾側に易動度を示す \\ “macro-ck"42症例の臨床的意義について \\ ○池田 敏子・長谷部紀子 - 稲井 真弥 (大阪医大 - 中検) \\ 延原美津子・関本定 (大阪医大・放射線部) \\ 金光 房江 (食敷中央病院)}

現在Creatine kinase ( 以下CK ) には 3 つのアイソザイム、CK-MM、CK-MB、CK-BBがあるでが知られている。 てれらとは別にCK-MMよりあ陰極側に易動度を示すCK-アイソザイムがあり、尤らにより報告されている。それに よると “macro-ck” の物理化学的性質は比較的熱に対して安定で、尿素に対しては不安定である。また免疫学的性質 としてはanti-ck-MMによって阻害を受けにくい性質を有している。今回我々は癌患者において42症例の“macrock"を見い出し、それらに一定の傾向が認められたので報告する。

対象および方法

検索対象は大阪医大病院放射線部RIA測定室において、昭和 55 年 9 月から昭和 56 年 12 月までの約 1 年半に、carcino cmbryonic antigen ( 以下CEA) 測定依頼のあった患者血清で、CEAが $20 \mathrm{ng} / m \ell$ 以上（正常值は $2.5 \mathrm{ng} / \mathrm{m} \ell$ 以下）の 45 症 例についてCK-アイソザイムを測定した。CEA はCEA・RIAKIT（ダイナボット社製）を用いてサンドイッチ法にて 測定を行なった。CK-アイソザイムは支持体にTITAN-III -ISOFLUR（ヘレナ社製）を用いて電気泳動を行ない、螢 光法にて測定した。T-CK 活性はRosalki-Oliverの方法に基づき、CPK-SVR・シノテスト（calbiochem 社製）を用 いて、自動分析装置 Cent. Chew. 400 を用いて測定した。

結 果

1）45例中42症例において “macro-ck”が認められ、出現頻度は $91.1 \%$ と非常に高頻度であった。“macro-ck”が認 められなかった 3 症例は検体測定回数が各々 1 回きりであり、 $\mathrm{T}-\mathrm{CK}$ 活性が $11 \mathrm{U} / \mathrm{L} 30^{\circ} \mathrm{C} 、 38 \mathrm{U} / \mathrm{L} 30^{\circ} \mathrm{C} 、 23 \mathrm{U} / \mathrm{L} 30^{\circ} \mathrm{C}$ と低く、また $-30^{\circ} \mathrm{C}$ のリーザーでの保存期間が 6 ケ月〜 10 ケ月と非常に長かった。

2) “macro-ck”が認められた検体のCEA は $20 \mathrm{ng} / m \ell$ 以上と非常に高值ではあったが、 $\alpha$-Feto-protein（以下 $\alpha$ フェト) は正常值 ( $20 \mathrm{ng} / m \ell$ 以下) であった。

3 ) “macro-ck” が認められた 42 症例の内 CK-アイソザィムの測定回数が 1 回きりは 18 症例で、他の 24 症例は 2 〜 7 回の測定を行なった。ての時同一患者検体において "macro-ck"はほとんどの場合に認められたが、一部症例にお いては出現したり出現しなかったりする場合があった。

4 ) “macro-ck” が認められた症例の診断名は、肺癌 6 名、胆のう（管）癌 5 名、胃癌 9 名（ stage III 以上）、直腸 癌 5 名、大腸癌 5 名、結腸癌 3 名、乳癌 3 名、子宮癌 2 名、膀胱癌 1 名、膵臓腺癌のう腫 1 名、骨䯣腺腫 1 名、腫瘍 骨転移 1 名であった。

5) これら検体で認められた “macro-ck” の物理化学的性質は $56^{\circ} \mathrm{C} 5$ 分の熱処理に対して比較的安定であり、また 2 M/L 4 時間の尿素処理に不安定であった。免疫学的性質としてヤギ由来、CK-MM（ヒト）阻害抗体（CicaMERCK 社製）によって阻害されにくい性質を有した。

まとめ

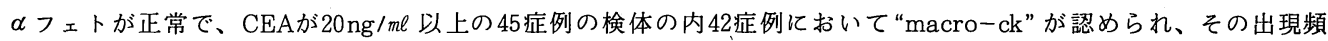
度は $91.1 \%$ 之非常に高いものであった。乙れらのととは“macro-ck”と癌との深いかかわりを強く示唆するあのである。 macro

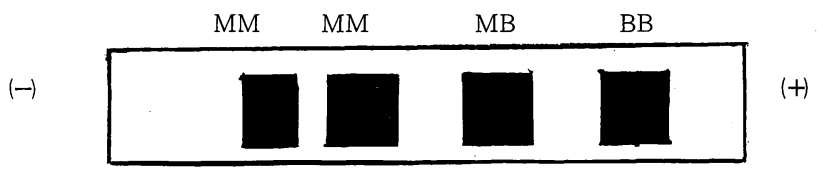

Fig 1

文献 1) Yuu, H. et al. : Clin. Chem., $24: 2054$, (1978)

2 ) 尤芳上他 : 生物物理化学., $23: 1,(1979)$

3 ) 尤芳上他 : 生物物理化学., $24: 3,(1981)$

4 ) 金光房江他：生物物理化学., $24: 1,(1980)$

5 ) 金光房江他：生物物理化学., $24: 4 ;$; (1981)

6 ) 金光房江他 : Clinica Chimica Acta , 112 (1981) $275 \sim 283$ 


\section{4. 小児に一過性に見られた易動度の速い \\ Alkaline Phosphatase Isozyme の 4 例}

○塚田 敦子・塚田 敏彦・中山 年正・北村 元仕

(虎の門病院・生化学・冲中成人病研)

肝性アルカリホスファクターゼ (ALP) 以上飞易動度が速く $\alpha_{1} \alpha_{2}$ glob.位を示すALPKは, Kasaharaアイソザイム1) と骨性 ALP2）などの悪性腫場産性 ALP が知られている。この $\alpha_{1} \alpha_{2}$ 位 ALP アイソザイムは腫愓以外では, わずかに軽度 胃腸障害を伴なら 21 歳男性で一過性に見られた報告 3 )があるのみである。

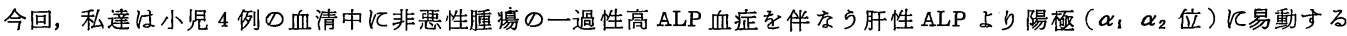
異常 ALPを経験したので，をとめて報告する。

\section{【症例】}

Case1：2歳女児。生後 6 ケ月頃より左強直母指で, 腱鞘切開手術のため入院。術前ALP1 $25 \mathrm{KA}$ 単位。

Case2：5 歳女児。1 歳頃から左渗出性中耳炎と慢性扁桃炎を繰返し, 扁桃炎手術のため入院。術前 ALP100KA 単位。 Case3 : 5 歳男児。 3 歳頃上りの反復性耳下腺炎のため精査入院。腫張洔ⒶLP45KA 単位。

Ca se4：2 歳女児。1 1 歳頃加頭頂部に母指頭大の良性腫

煬発生。頭蓋骨腫愓摘除手術のため入院。術前ALP6 8KA

単位。

らずれのCaseす術後あるいは消炎時, 血清ALPは20KA 単位以下に低下正常化し，それに伴なって異常 ALP 注消失 し正常小児骨バターンとなった。

【材料および検索方法】

1）試料：患者血清

2) ALP 活性 : $\mathrm{MgC} \ell_{2}$ 添加 $\mathrm{Kind}-\mathrm{King}$ 変法。

$\mathrm{K}_{\mathrm{m}}$ 值は $\mathrm{p}-\mathrm{NPP}$ を基質とする $\mathrm{rate}$ 法。

3） I sozyme：PVP 寒天ゲルと $5 \%$ \%ホリクリルアミドゲ

ルを支持体としindigo 発色した。

4) Neuraminidase 処理: $0.2 \mathrm{IU} / m \ell$ Neuraminidase pH6.0, $37^{\circ} \mathrm{C} 3$ 時間反応後, 透析し試料とした。

5）ゲル沪過：TLGは Sephadex G-200 Superfine, カラムクロマトはSephacryl S-300で行なった。

\section{【結果】}

し）電気泳動パターンはFig.1亿示した。骨性ALPより陽極寄りに易動する異常分画があり，4例とす同様なパターン を呈した。

2）血清ALPの性質は Table 1 K示したように，4 例とす骨性ALPの性状と類似する結果となった。

3）一例（Case 2) 飞つレては，異常ALPを血清より分離して性状を詳しく調べた。

【まとめ】

4 例の小児血清に見られた易動度の速いALPは一過性に骨性ALPの上昇に伴ない出現し, その性状は骨性ALP と類 似するるのであった。てのアインザイム出現時には肝機能など他の生化学データーは正常值を示し, 特定疾患との関連 性がない点で, 従来報告されている腫煬産生ALPとは異なっている。しかる，てのようなパターンを示した4例がらず れる小児であるととは注目されることである。

\section{【文【献】}

1) Higashino, K. et al, : C I in.Chim. Acta, 40,67, 1972

2）塚田敏彥他: 生物物理化学, $25: 234,1981$

3) S. B. Rosalki et al, : C i in Chim. Acta, 73:149, 1976

Table 1. Properties of ALP Isozyme

\begin{tabular}{|c|c|c|c|c|c|c|}
\hline & \multirow{2}{*}{$\begin{array}{l}\text { Case } 1 \\
(\text { Y.S.) }\end{array}$} & \multirow{2}{*}{$\begin{array}{l}\text { Case } 2 \\
(\mathrm{M} . \mathrm{H} .)\end{array}$} & \multirow{2}{*}{$\begin{array}{r}\text { Case }{ }^{3} \\
(\mathrm{~S} . \mathrm{K} .) \\
\end{array}$} & \multirow{2}{*}{$\begin{array}{l}\text { Case } 4 \\
(\mathrm{Y} . \mathrm{Y} .)\end{array}$} & \multicolumn{2}{|c|}{ Normal serum } \\
\hline & & & & & Liver & Bone \\
\hline Mobility in & $\begin{array}{l}\alpha_{1-\beta}-\beta \\
\alpha_{1-\beta}\end{array}$ & $\alpha_{1}-\beta$ & $\begin{array}{l}\alpha_{1}-\beta \\
\alpha_{1}-\beta\end{array}$ & $\begin{array}{l}\alpha_{1}-\beta \\
\alpha_{1}-\beta\end{array}$ & $\begin{array}{l}\alpha_{2} \\
\alpha_{2}\end{array}$ & $\begin{array}{l}\alpha_{2} \beta \\
\alpha_{2} \beta\end{array}$ \\
\hline $\mathrm{Km}$ (p-nitrophenylphosphate) mM & 0.57 & $0.56^{r}$ & 0.54 & 0.58 & 0.56 & $\begin{array}{l}\alpha_{2} \beta \\
0.58\end{array}$ \\
\hline $\begin{array}{rlr}\text { Heat stability }(8) & 54^{\circ} \mathrm{C} 7.5 \mathrm{~min} . \\
& 56^{\circ} \mathrm{C} 10 \mathrm{~min} .\end{array}$ & $\begin{array}{r}23 \\
5\end{array}$ & $\begin{array}{r}27 \\
5\end{array}$ & $\begin{array}{r}24 \\
4\end{array}$ & $\begin{array}{r}32 \\
9\end{array}$ & $\begin{array}{l}56 \\
19\end{array}$ & 21 \\
\hline Inhibition by $5 \mathrm{mM}$ Phenylalanine & 15 & 16 & 17 & 18 & 18 & 14 \\
\hline $\begin{array}{l}5 \mathrm{mM} \text { Leucine } \\
5 \mathrm{mM} \text { Homoarginine }\end{array}$ & $\begin{array}{l}33 \\
81\end{array}$ & $\begin{array}{l}30 \\
78\end{array}$ & $\begin{array}{l}30 \\
82\end{array}$ & $\begin{array}{l}30 \\
76\end{array}$ & $\begin{array}{l}32 \\
78\end{array}$ & $\begin{array}{l}32 \\
80\end{array}$ \\
\hline Neuraminidase Sensitivity & + & $\stackrel{+}{7}$ & + & $\stackrel{+}{7}$ & + & + \\
\hline Molecular Size (TLG) & 1.7 & 1.7 & 1.7 & 1.7 & 1.7 & 1.7 \\
\hline
\end{tabular}




\title{
35. 献血者において見出されたLDH結合性免疫グロブリン
}

\author{
○堤康 英 (福岡県赤十字血液センター) \\ 長 嶺 光 隆 (九州大·医·中検)
}

は $し$ め $に$

近年, LDH結合性免疫 glob の症例が多数見出され，疾患との関係が検討されて，特に lgA 結合例には健常者が多い事が知られている1)。 今回, 対象が健常者である献血者について血清LDHアインザイムを分析する機会があり，15例の lgA 結合例を経験したので，検出頻度，年令 分布，およびLDH各分画比などについて報告する。

$$
\text { 試料打よび方法 }
$$

1）試料：16才から64才までの男性 5672 名，女性 4328 名の献血者血清。

2）LDH総活性值測定法：乳酸を基質とし，テトラゾリウム塩を用いたLDH-L(ヤトロン社製)を使用し，活性はWróblewski 単位で表わした。

3）LDHアイソザイム分析法：アガロースを支持体とし，ピロリン酸ーバルビタール緩重液で泳動後，乳酸, NAD, PMS, NTB，を含む反応液で 染色した。

4）デンシトメトリー：自記濃度計（PAN-FVJOOKOO CO,LTD）により570nmの波長で測定した。

5） LDH結合性免疫 glob の同定法：免疫固定法および対向流免疫電気泳動法 ${ }^{2)}$,3) によって同定した。

$$
\text { 結 果 括よ びをと め }
$$

1） LDH結合性免疫 glob の症例は男性 9 例，女性 6 例の合計 15 例あり，免疫 glob の種類はすべて lgA-k 型である。

2）免疫 glob 結合例の検出頻度は，表 1 と示すと打り結数 $15 / 10000(0.15 \%)$ ，男性 $\frac{9}{5672}(0.16 \%)$ ，女性 $6 / 4328(0.14 \%)$ である。これ を各年台別に比較すると 20 才台から 30 才台の頻度が高い。

\begin{tabular}{|c|c|c|c|c|c|c|c|c|c|}
\hline 年 台 & 結合例 分析例 & 頻 & 男 & 女 & 年 台 & 結合例 分析例 & $\begin{array}{l}\text { 頻 度 } \\
(\%)\end{array}$ & 男 & 女 \\
\hline$\sim 20$ & 180 & 0.05 & 1 & & $41 \sim 50$ & 44 & 0.06 & & 1 \\
\hline $21 \sim 30$ & 4. 2478 & 0.16 & 4 & & $51 \sim 60$ & 262 & 0.08 & 1 & \\
\hline $31 \sim 40$ & $8 / 1909$ & 0.42 & 3 & 5 & $60 \sim$ & 527 & 0 & & \\
\hline
\end{tabular}

表 1 年令分布

3）免疫 glob 非結合例 100 例について，LDH総活性值，およびデンシトメトリーによって測定した各分画活性値の土2SDの範囲を求めた。そし て兔疫 glob結合例のLDH総活性値，各分画活性値，さらにそれぞれの正常上限に対する比率を表 2 に示した。

\begin{tabular}{|c|c|c|c|c|c|c|c|}
\hline \multirow{2}{*}{\multicolumn{2}{|c|}{$\begin{array}{l}\text { 非結合例 } 100 \text { 例 } \\
\text { (平均士 2SD) }\end{array}$}} & $\mathrm{LDH}$ & $\mathrm{LDH}_{1}$ & $\mathrm{EDH}_{2}$ & $\mathrm{LDH}_{3}$ & $\mathrm{LDH}_{4}$ & $\mathrm{LDH}_{5}$ \\
\hline & & $244-290$ & $73-90$ & $79-109$ & $56-64$ & $12-24$ & $11-19$ (wr ó) \\
\hline \multirow{15}{*}{ 結 合 例 } & 1. & 675 & 165 & 176 & 211 & 84 & 38 \\
\hline & 2. & 572 & 124 & 134 & 206 & 62 & 42 \\
\hline & 3. & 447 & 114 & 121 & 144 & 32 & 36 \\
\hline & 4. & 427 & 117 & 122 & 120 & 39 & 27 \\
\hline & 5. & 427 & 119 & 120 & 118 & 40 & 30 \\
\hline & 6. & 422 & 108 & 122 & 124 & 32 & 34 \\
\hline & 7. & 414 & 112 & 120 & 116 & 36 & 26 \\
\hline & 8. & 412 & 108 & 118 & 118 & 38 & 28 \\
\hline & 9. & 402 & 98 & 117 & 122 & 36 & 27 \\
\hline & 10. & 397 & 101 & 112 & 127 & 32 & 25 \\
\hline & 11. & 394 & 98 & 116 & 124 & 33 & 22 \\
\hline & 12. & 394 & 102 & 113 & 118 & 31 & 28 \\
\hline & 13. & 386 & 97 & 114 & 115 & 38 & 21 \\
\hline & 14. & 378 & 96 & 112 & 120 & 26 & 24 \\
\hline & 15. & 317 & 83 & 100 & 97 & 20 & 16 \\
\hline 平 均 & & $431(1.5)$ & $109(1.2)$ & $121(1.1)$ & $132(2.1)$ & $39(1.6)$ & $28(1.5)$ \\
\hline
\end{tabular}
表 2 LDH総活性値と各分画活性値

まず総活性値は，正常上限の 1.1 倍 23倍で平均 1.5 倍である。次に各分画活性值は，いずれの分画においても上昇がみられ，特にLDH ${ }_{4}, 5$ に顕著 である。

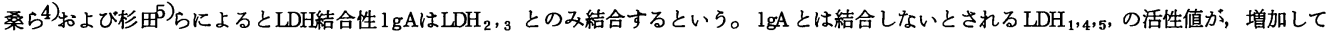
いることが示されたが，これらの分画の上昇機序の解明は，今後の課題である。

文献 1) 長嶺光隆: 生物物理化学: $21,193,1977$

2) 須藤加代子ら：生物物理化学：23,145, 1979

3）長嶺光隆ら：生物物理化学： $24,275,1981$

4) 桑克彦占：臨床病理：23(補冊) : 240,1975

5) 杉田収ら：生物物理化学：22,151, 1978 


\section{6. 高LDH 5 血症を思わせ る IgG結合型LDHについて \\ 白方 隆晴・市川 正之 (岡山済生会総合病院・臨床検查)}

1967 年 Canrotがルボイド硬変症の患者血清中にIgA と結合した LDHを見つけて以来, 免疫グロブリンと結合し た LDHを持つ多くの症例が報告されている。加野らはとのようなLDHアノマリーを，電気泳動時に現われる異常パタ

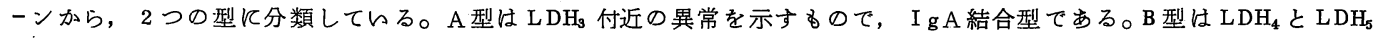
の間に異常バンドを示し，I g G 結合型である。

今回, 我々は $\mathrm{LDH}_{5}$ 付近飞泳動する $\mathrm{Ig}$ 結合型 $\mathrm{LDH}$ を持

つ症例を経験したので報告する。

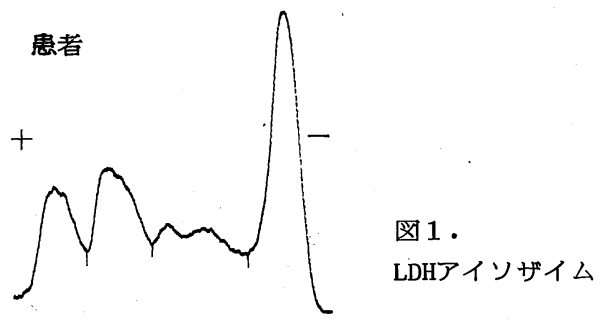

【症例 】

64 才女性, 肝硬変症 (肝癌の疑的)

\section{【検查成績 】}

白血球 5200 (好中球 $61 \%$, リンパ球 $34 \%$ ).

赤血球 $320 \times 10^{4}$

肝機能検查: GOT $171 \mathrm{KU}, \mathrm{GPT} 161 \mathrm{KU}$, ALP $9.2 \mathrm{KAU}$, $\mathrm{ChE} 0.40 \triangle \mathrm{PH}, \mathrm{LDH} 1230 \mathrm{WU}, \mathrm{ZTT} 19.2 \mathrm{KU}$, ビリルビノ $11.9 \mathrm{mg} /$ $\mathrm{d} \mathrm{l}($ 直 $8.7 \mathrm{mg} / \mathrm{dl}$ ), LAP $214 \mathrm{GU}, r-$ GTP $112 \mathrm{mU}$ ICG 15 分值 $45 \%$

総蛋白 $6.9 \mathrm{~g} / \mathrm{dI}$ (アルブミン $46.2 \%, \alpha_{1} 2.5 \%, \alpha_{2} 4.9 \%$, B $4.2 \%, \Upsilon 42.2 \%$ )

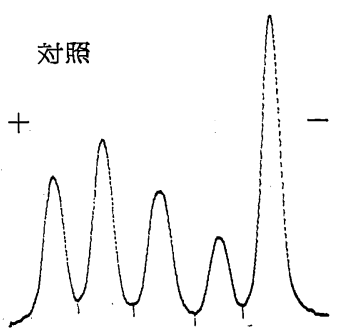

$\mathrm{RA}+$, HBs 抗原一, HBs 抗体一, AFP $950 \mathrm{ng} / \mathrm{ml}$

LDH アイソザイム

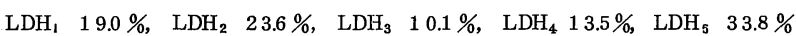

図 1 亿示すように $\mathrm{LDH}_{1}, 2,3,4$ は, 対照に比べてやや压やけた感じがする。免疫固定法により $\mathrm{LDH}_{5}$ の位置に IgG-Iambda と結合したLDHを同定できた。

薄層ゲル汇過法では図 2 ス示すように, 異常LDHはG分画よりやや高分子側に流れていた。

\section{【考察】}

我々は昨年, 肝硬変症の患者血清中に $\mathrm{LDH}_{5}$ の位置飞泳動 するIgG-kappa 結合型 $\mathrm{LDH} と \mathrm{LDH}_{3},{ }_{4}$ の位置に泳動する Ig G-I a mbda 結合型 LDH が共存する症例を見つけ報告した。 その症例之今回の症例は共に肝障害があり,しか子, 高ら $\mathrm{LDH}_{5}$ がIg 結合型であるという共通点を持つ点で興味深い。 両症例のLDH アイソザイムパターンは, 何れす通常のすの とはやや異なっており，注意梁く見れば見落すことはない ように思う。

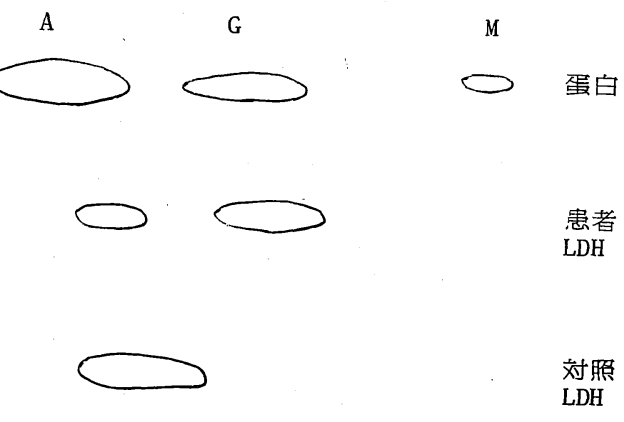

図 2, 薄層ゲル沪過法 


\section{7. 免疫電気浸透法を応用した ALP 結合免疫globの同定 ○柴田 宏・戸沢辰雄・森田祐代・林 景子・松岡 瑛 \\ (兵庫医大・中検)}

A L P 結合免疫 globの検出飞は，寒天内免疫電気泳動法（IＥE，P法）飞上る方法が沉用されている他，交差免 疫電気泳動法ささらにセロゲル膜を用いた I E P 法，免疫固定法に上る報告がみられる。

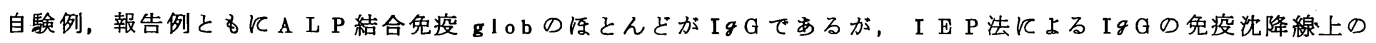
A L P 活性は，fast $r$ 位の一部に限られて見られるととに着眼し，A L P 結合免疫 globを高感度に検出する目的 て免度電気浸透法 ( ES 法) の応用を試みた。

材料：8 例の A L P 結合免疫 $\mathrm{g} 1 \mathrm{ob}$ を持つ患者血清を用いた。対象として 1,000 例の患者血清を用いた。

方法：1. 免疫電気浸透法。门） $1.2 \%$ 寒天ゲル板を使い, 試料孔と抗体孔の中心距離を $6 m \pi と し$, それぞれ 10 $\mu \ell$ の被験血清と抗血清を入れ， $3 \mathrm{~m} \mathrm{~A} / \mathrm{cm} ， 60$ 分通電。さらに二次元方向飞 $3 \mathrm{~m}^{\mathrm{m}} \mathrm{A} / \mathrm{cm} ， 60$ 分通電を行った。 ii)市販

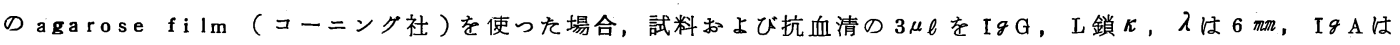
9 mの距離にスボットし，150V 30 分通電した。泳動後 3 日間生理的食塩水にて脱蛋白後A L P 染色を行った。i),

ii）とるべロナール緩衝液 ${ }_{\mathrm{P}} \mathrm{H} 8.6$ を使用した。

2. その他の方法：IE P 法。二元免疫拡散法、免疫混合法を行った。

3. 特異抗血清はD A KO社製を使用した。

成樍：ALP結合免疫 globを有する血清では，それぞれ特異抗血清との沈降線に一致して A L P 活性が認められ， A L P 結合免疫 g 1 ob の同定は容易でる。高A L P 血症でしか S l ow $\beta$ 位, つまり抗原抗体孔間飞高A L P 活性 がみられる血清では判定が不能てある。この場合，さらに二次元電気泳動により，沈降線との重複を分離させ判定し える。A L P 結合免度 g lob 例では沈降線上のA L P 活性は, 一次元泳動の場合と不変である。1.2\%寒天平板では, 非結合 A L P 活性の洗净が十分に出来ないが, a g a r ose f j Im では洗浄が十分に行え，余分な A L P 活性は認めら れず，二次元の必要はない。しかし少数例であるが，免疫沈降物中に混入する高 A L P 活性が洗浄出来ず，全ての特 異抗血清との沈降線KA L P 活性が認められる症例が存在する。との場合，対照として抗卜ランスフェリン血清との 沈降線にすA L P 活性が認められるととにより，False positiveの例と推定した。との様な場合，最終的に，

A L P 結合免疫 globの有無は, 他法での確認が必要である。

E S 法ての検出成績': 1,000 例の患者中 2 例の A L P 結合 I g G 例を検出した。

E S 法の検出感度の成績： 8 例のA L P 結合 I g G 例飞おんて,アイソザイム分析て 1 例の A L P V が検出できか つた。二元免疫拡散法で 4 例の免疫クロブリンの H・L 鎖ともに， 3 例は L 鎖のみ同定出来たが，残る 1 例は H・L 鎖ともに同定てきなかった。E S 法, I E P 法, 免疫混合法では全例同定可能であった。さらに8 例中 3 例の潰痬性 大腸炎患者の経時的な検索で，I E P 法で検出出来なくなった時です E S 法では検出でき，E S 法での検出感度が優 れているととを認めた。

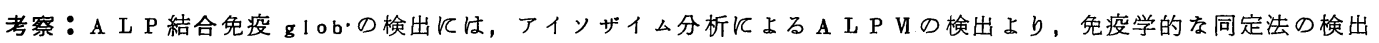
感度が優れている。免疫電気泳動法では沈降線上のAＬＰ活性の検出は容易で，反応時間を延長させるととにより微 量活性でる検出でるが，ES 法はさらに感度が優れている。免疫混合法は感度は優れているが，抗血清を大量て必 要とする。Protein A 利用した方法は最も検出感度は高いが， Subclasskより検出不能例の存在が予想される。

A L P 結合 I g A 例は経験していないが, L D H 結合免疫 g lob Kつんての本法の成績は, Ig Gの場合, 検出でをな がったが，IgAの場合，検出がでをたで，ALP結合 IgA例でる，本法で検出でをると推定している。

以上の成績から，本法は A L P 結合免疫 $\mathrm{g} 1 \mathrm{ob}$ 高感度な検出法であり，その簡便さはスクリーニンク検査として も有用な方法と考えた。 


\section{8. 潰瘍性大腸炎患者におけるALP-Ig G複合物の動態 ○藤原弥栄子・戸沢辰雄・太子 䉂・桑原純子・柴田 宏 (兵庫医大 · 中検)}

電気的易動度のおていALPVは, 潰痬性大腸炎の臨床経 過に関連して出現するとされている。さらにALPVは,肝あ るいは骨 ALPとIgGの複合物であるととが, 加野らにより 報告された。今回, Protein $\mathrm{A} の \mathrm{IgG}$ ○の吸着性を応用し $\tau$, 潰痬性大腸炎の病期飞おける ALP-I g G 複合物の動態 を，4例の患者で観察した。

【方【法】

1. ALP 活性り測定には、「ニューKホス」キット(栄研) を用いた。

2. 酵素免疫電気泳動法 (EIP)等の免疫学的手技に上り, ALP-I gGを確認した。特異抗血清は D AKO社製を用い た。

3. Protein A-Sepharose CL-4B（ファルマシア社)との 吸着性は，Kurt Bauer らの方法に準じ1), 血清 $500 \mu \ell に$ Prote in A-Sepharose CL-4Bを各々 25,50,75 mg 混和 L, 遠沈後の上清中 ALP 活性とIgG 量, 並びに沈澱物中 の ALP 活性を測定した。

4. ALPアイソザイム分析は, PAG-DI SC電気泳動法で行 なった。をた, Protein AKよるIgG吸着後の各上清に つ々て, ALPYの減衰から, ALP-IgGがProtein A K 吸着するととを確認した。

\section{【結果】}

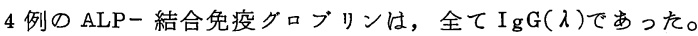

患者K. h(16才, 男性)：1981年 5 月まで寛解期であったにもかかわらず ALP U が観察された。活動期への移行直後 の 7 月まで, ALP Vの活性は増加したが，その後約半年の活動期において徐々に減少し，再び寛解期へ移行するのに伴 ら消失した。しかし, ALP V が消失しても, Protein A-Sepharose CL-4B 中のALP活性は隇少していたが存続し, 約 1 ケ月後に消失した。

患者K.k（45才,男性）：1981 年 4 月の活動期飞 ALPVを認めた。5 月以降寛解期に入りALPVは消失し,寛解期が続 くにつれてProtein A-Sepharose CL-4B 中のALP 活性を減少し，半年後には活性が認められなくなった。

患者 I.m(34才,女性)：8 ケ月にわたって寛解期が続いているが, ALPVは高活性で持続して存在している。しかし， ALPYの活性は漸減し, Protein A-Sepharose CL-4B 中のALP活性にも減少がみられる。

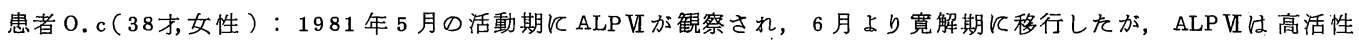
で存続している。ALPYも，Protein A-Sepharose CL-4B中のALP活性も減少がみられない。なお，4例ともProtein A-Sepharose CL-4B中の ALP 活性と，総ALP 活性及び I gG 濃度との関連性は明らかでなかった。

\section{【考察】}

ALP Vは潰瘍性大腸炎の活動期に出現し，寛解期では消失すると報告されている。しかし，アイソザイム像でALPV が消失していても，ALP-IgGが存在しているととが今回判明した。さらに寛解期でALP-IgGは徐々に減少するが， 存在を認めなくなるのに長期間を要した。一方, 寬解期にも活動期と同様に, ALP-I gGが存続している症例もあるが, 症例間におけるこの差は判明しなかった。

今回の結果から，ALP-Ig G 動態の観察には，アイソザイム分析よりすProtein A-Sepharose CL-4B Kよる方法の 方が検出感度が優れ, 病態解析の上に.有用と考えた。

最後に，症例を提供して下さった，兵庫医大第 4 内科，大腸疾患研究クルーブの先生方に深謝します。

\section{【文献 】}

1) Kurt Bauer et.al: Clin.Chem. $26: 297,1980$. 


\section{9. マクロアミラーゼの検討 \\ ○林和子・桶村 厚子・永井 博美 \\ 富安 悟芳・宮崎龍之輔 (九段坂病院・検查科) \\ 浅川 英男 (東京医歯大·医・中検)}

1. 目的

1964 年，WILDINGらKより持続的高アミラーゼ血症の原因としてクロブリンと結合したアミラーゼが報告され， ついで 1967 年, BERKらが高分子アミラーゼの性状につを種々の可能性があるととを示唆し，とれらををとめてマク ロアミラーゼ血症と命名した。大部分のマクロアミラーゼ血症は免疫グロブリンと結合して生じたすのであるととが 推測され，自己免疫疾患，自己抗体との関連性が注目されてきた。

今回，私共はマクロアミラーゼ血症が疑われた 5 例につき検索したので，その成績につき報告する。

2. 材料及び方法

1) アミラーゼ・アイソザイム（不連続楥衝液を使う方法）

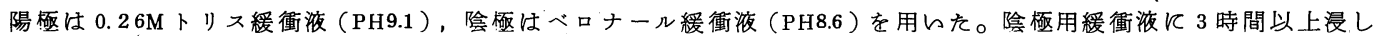
たセルロゲルに試料をバンド状に塗布し，電気泳動した。泳動終了後のセルロゲルにブルースターチを混じた寒天板 を重ね，37゚ 1 時間加温し、メタノールにて固定した。

2 ）醳素免疫電気泳動

セルロゲルに血清をスボット状に塗布し,通常の方法で分画する。泳動終了後，抗血清をしみこませをロ紙をはりつ け，てれを泳動バラフィ中で 1 晚反応させた。膜からパラフィンおよび未反応のタンパクを除を，アイソ'エンザイ ムの時と同様アミラーゼ染色をおてなった。

3. 成

1) アミラーゼ・アイソザイム

症例 $1 ： \mathrm{~S}$ 型上りも陽極側飞幅㕕ら異常なバンドを認めた。 症例 $2 ： \mathrm{P}$ 型よりる陽極側に幅広い異常なバンドを

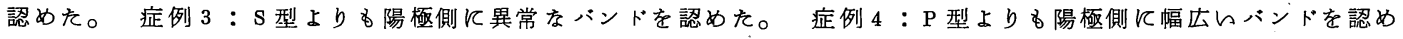
た。症例 5 ： $\mathrm{S}$ 型よりる陰極側に幅広い異常なバンドを認めた。

2) 醇素免疫電気泳動

症例 1 : 抗 IgA，抗 $\kappa$ K対する沈降線に一致してアミラーゼ佸性を認めた。症例 2 : 抗 IgA，抗 $\kappa$ に対する沈降 線に一致してアミラーゼ活性を認めた。症例 3 ：抗 I g A，抗 $\kappa$ て対する沈降線に一致して弱いアミラーゼ活性を認 めた。症例 4 ：抗 I g A , 抗 $\lambda$ に対する沈降線に一致してアミラーゼ活性を認めた。又抗 $\kappa$ に対する沈降線にる一致 して非常に弱いアミラーゼ活性が認められた。症例 5 : 抗 $\mathrm{I} g \mathrm{G}$ ，抗入に対する沈降線に一致してアミラーゼ活性が あるようであるが明らかでない。

4. 考 察

マクロアミラーゼ血症とは、なんらかの原因により血中アミラーゼが巨大分子化し，それに基ゔくしんぞうからの 排せつ障害に上りアミラーゼが血中に停留し高アミラーゼ血症が持続する病態である。マクロアミラーゼの存在様式 として，1）アミラ一ゼと免疫クロブリンとの結合，2）多糖類などの蛋白質以外の物質との結合，3）アミラーゼ の重合，以上の 3 つの形が考えられている。そのうち免疫クロブリンとの結合ではIgA，Ig G，と結合したるのが多 らようである。今回も5 例とも免疫グロプリンと結合したるのであるととが推測された。そのうち 2 例はIgA，型 に結合しているととが判明した。残り 3 例は㶩降線と一致するアミラーゼ活性が弱く，2 例はIgA，1例はIgGと結 合しているらしいてとが推定された。との1例は異常アミラーゼが陰極側に泳動されているととから考えてるおそら くIgGと結合していると思われる。
5. 結
論

今回， 5 例のマクロアミラーゼ血症を経験し，そのうち 4 例が I $g \mathrm{~A}$ と結合し，1 例が I g G と結合しているととが推 測された。 


\section{0. カドミウム負荷家鬼の}

\section{血清アルカリフォスファターゼアイソザイムの変化 \\ ○荒 木 万 嘉(兵庫衛研) \\ 小 野 一 男(姫路循環)}

カドミゥム $(\mathrm{Cd})$ 負荷による家鬼の肝臓中 ALP の活性上年あるいは酵素組織化学的局在性の変化がみられている (第4 8 回日本衛生学会)。今回 Cd 負荷家鬼の血清 ALP アイソザィムについて検討したので報告する。

方 法

雌家鬼 $\left(2 \mathrm{~kg}\right.$ )を対照,投与群それぞれ 4 羽ずつ使用した。Cdは $\mathrm{CdC}_{12}$ を $\mathrm{Cd}$ として $1 \mathrm{mg} / \mathrm{kg} /$ 日, 5 週間皮下投与した。ALPの 抽出は臓器からはOkuboらの方法により, 骨からは山本らの n-butanol法により抽出した。ALPの活性測定は渡辺ら

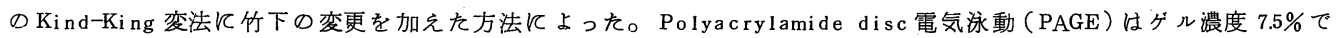
Gerbitz らの方法に従った。活性染色は $2 \mathrm{mMMgCl}_{2}$ を含む2 MAMP緩衝液 (PH10.2) $25 \mathrm{~m} \ell$ V P-tol uidine-5-bromo-3indolylphosp-hate 50mg 加えて発色液とし,37C30〜60分間行なった。SephadexG-200によるゲルロ過は $0.02 \mathrm{mMZn}$ $\mathrm{Cl}_{2}, 0.1 \mathrm{~m} \mathrm{M} \mathrm{Mg} \mathrm{Cl} l_{2}$ を含む10 m M Tris $-\mathrm{HCl}$ 緩衝液(PH7.5)で行なった。阻害試験は飯野らの方法に従った。免疫電気泳動 後の脂質染色は Sudan-Black B 法によった。

結 果

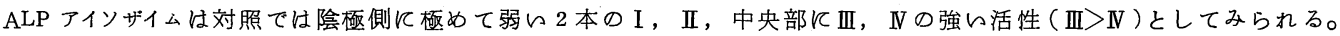
$\mathrm{Cd}$ 投与群では投与 1 週後には細孔ゲルに入らない活性（高分子 ALP）及び正に比べてNに相当する活性の増加が見られ た。I，IIK相当する活性には変化がみられなかった。各臓 器からのALPのPAGE と投与群血清のPAGEの比較では活性 増加のみられた $\mathrm{N} は$ 肝由来の $\mathrm{L}_{2}$ の易動度と一致した。 Sephadex G-200亿より投与群の血清及び肝ALPのダルロ 過を行なった。血清分画の $\mathrm{Px}, \mathrm{P}_{1}$ 及び $\mathrm{P}_{2}$ の $\mathrm{PAGE}$ では $\mathrm{Px}$ は細孔ダルに入らない高分子 ALPであり， $\mathrm{P}_{1}$ はIII, $\mathrm{P}_{2}$ はVVK それぞれ相当するALP活性を示した。肝 ALPの活性分画LF、 と $\mathrm{LF}_{2}$ は $\mathrm{PAGE}$ でそれぞれ $\mathrm{L}_{1}, \mathrm{~L}_{2}$ の易動度と一致した。 血清 $\mathrm{P}_{2}$ 及び肝 $L F_{2}$ 分画の阻害試験行なった。血清 $\mathrm{P}_{2}$ 分 画は $56^{\circ} \mathrm{C} 10$ 分で $3 \%, 3 \mathrm{M}$ 尿素で約 $30 \%, 5 \mathrm{mML}$-phenylalanineでは約 $54 \%$ の阻害率であった。肝 $\mathrm{LF}_{2}$ 分画では $56^{\circ} \mathrm{C}$ 10 分で $0 \%, 3 \mathrm{M}$ 尿素で約 $40 \%, 5 \mathrm{~m} \mathrm{ML-phenylalanineでは}$ 約 $65 \%$ の阻害率で, $\mathrm{LF}_{2}$ と $\mathrm{P}_{2}$ とは他の臓器のALP 亿比へ て PAGE及び阻害試験で一番よく似た性質を示し, Cd 投与 によって活性増加がみられたALPアイソザイムの, NK相当す る活性帯は肝由来のるのと考えられる。III に相当するALP の臓器由来は明らかでない。高分子ALP分画に氷冷下で n-butanol 処理を行なうと低分子化する。又免疫電気泳動 においてす Cd 投与群では原点位に ALP 活性の増加, 蛋白染 色及び脂質染色で $\beta$ リボ蛋白の著しい増加がみられ，更に $\beta$ リボ蛋白に ALP 活性を認めた。

SephadexG-200のPx 分画を免疫電気泳動したととろ, ALP活性は原点飞, 又脂質染色では $\beta$ リホ蛋白を認めた。 $\beta$ リポ蛋白沈澱物剤により処理した後, 免疫電気泳動を行 なったととろ $\beta$ リポ蛋白分画に大部分の活性がみられた。 このととから高分子ALPは $\beta$ リボ量白と複合体を形成し てレる可能性がある。

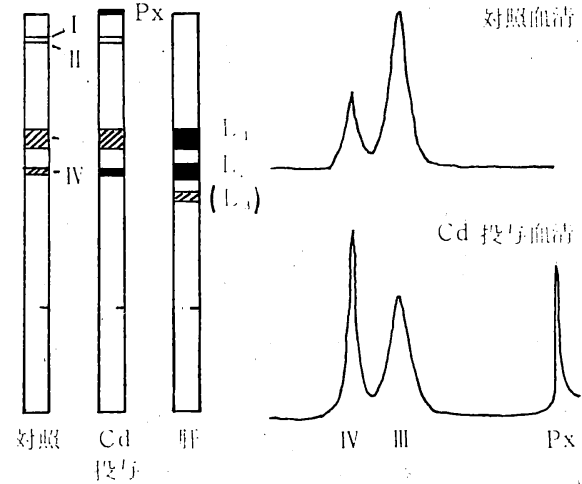

Fig. 1. Cd fuld.

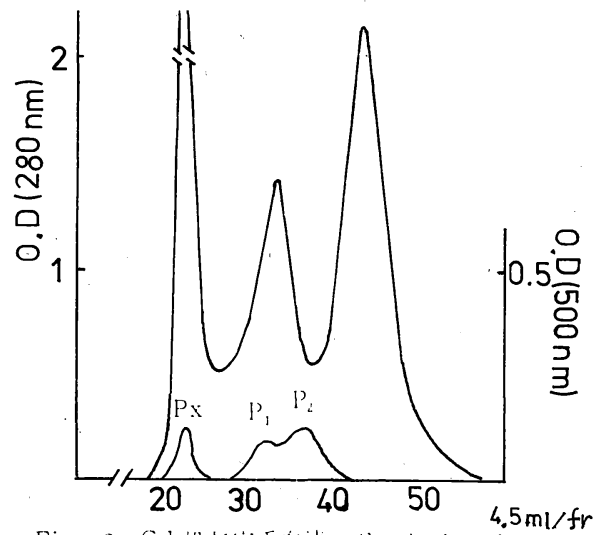

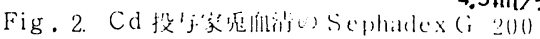
に上るゲルロ消 


\title{
41. Hypoxiaにおける
}

\author{
ラットの血液、臓器のLDH、CKアイソザイムの変化 \\ ○林 泰三 (大阪医大·病態検査) \\ 田中 孝生 (大阪医大・第 3 内科)
}

我々は昨年の本学会総会にて、心筋ホモジネートの䤃素活性、アイソザイムを報告し、甲状腺機能六進による肥大 心、hypoxiaの心筋の変化にもふれたが、今回はhypoxiaによる血中のてれらザイモグラムの変化を、その際の心筋 また肝のそれと比較するてとにより、臨床的に変動する䣼素活性、アイソザイムの意義についての分析を試みた。

〔材料と方法〕Wister 系雄ラットを用い、Solaroらの方法により心筋掞よび肝臓を、Triton X-100の存在下でホモジ ナイズし、17,000 gで15分間遠心、上清を測定に供した。各種醉素活性はAutoanalyzer、Centrifi chemを用いてUV法 にて測定した。ホモジネートについては、Lowry法にて測定した蛋白林当りの活性として表わした。LDH一アイソザ イムはポルEフイルム、CKーアイソザイムはタイタンIII による電気泳動法にて測定した。hypoxia はラットをガラス 鐘に入れ、室素ガスを注入し、酸素含量をroom airの $1 / 2$ 以下とし呼吸させ作成した。

〔結果〕hypoxia の心筋は対照に比し、醉素活性の変化は著明ではなかったが、LDHーアイソザイムはLDH

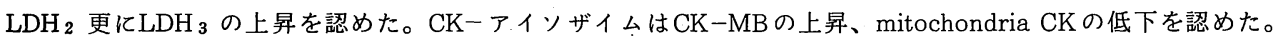
hypoxia の血浆LDH ザイモグラムは、その時の心筋のそれに比し、 $\mathrm{LDH}_{1} \mathrm{LDH}_{2} \mathrm{LDH}_{3}$ はいずれも低く、 $\mathrm{LDH}_{5}$ が高く、肝のそれに近い型を示した。血浆CKザイモグラムは、心筋に比し CK-BB の上昇が著明で、その他 CK-MB、 -MM な゙゙は心筋に似た型をとった。肝はCK 活性が低く、不明の分画も認め、血浆のザイモグラムへの影響はあきらか ではなかった。

hypoxia から開放した短時間後の回復期においては、血浆LDHザイモグラムは、肝型に近かったものが $\mathrm{LDH}_{1}$ 、 $\mathrm{LDH}_{2}$ の上昇、 $\mathrm{LDH}_{4} 、 \mathrm{LDH}_{5}$ の低下と心筋型に近ずく所見を示し、CKザイモグラムも、CK-BBが低下し、

$\mathrm{CK}-\mathrm{MB} 、-\mathrm{MM}$ は上昇し、心筋障害の所見はより著明となった。

〔考察ならびに結語〕hypoxiaの実験は心臓への侵襲を目的とし、好気的な心筋に嫌的状態をもたらせたすのである。 その際 $\mathrm{LDH}_{1}$ が低下し、H-subunitが $\mathrm{M}$ - subunit $に$ shift する傾向がみられ、CK-MBの上昇むみられた。その時の血 中のそれらの変化は、必ずしあ心筋の変化に一致するものでなく、短時間後の回復期の方が、心筋障害をよく反映す る所見が得られた。このことは臨床的な醉素学的分析に際し、臟器变化之血液所見の間に介在する循環動態への考慮 あ必要であることを示すあのである。

〔文献〕Solaro, R.J. et al., Biochim. Biophys. Acta, $245: 259,1971$. 


\section{2. ラットの背側部および腹部前立腺蛋白質の SDS-電気泳動法による比較分析 松尾雄志・ ○根木哲朗・西望・和田文雄 (香川医大・内分泌)}

ラット前立腺は、背側部前立腺（DLP）と腹部前立腺（VP）から成り、その分化と構造 および機能の維持は、男性ホルモンに依存している。VPとDLPは、ともに同一原基から 発生し、組織学的にまた生理学的に類似しているにもかかわらず、男性ホルモンに対す る応答には両者の間で差があるここが知られている。今回は、VPとDLP の類似点および 差異を蛋白質しベルで調べるために、両者の核、ミクロソームおよび可溶性画分を調製 し、SDS-ポリアクリルアミドゲル電気泳動（SDS-PAGE）による比較を行った。

実 験方法

SD系雄ラット（体重：400〜450g)のVPとDLP から、プロテアーゼ阻害郕”( $1 \mathrm{mMPMSF}$ ) 共 存下に核、ミクロソームおよび可溶性画分を調製した。SDS-PAGEは、Laemmiiの方法に 準じて行い、核画'分については同一DNA 量、その他の画分については同一蛋白質量を含 む試料を泳動して比較した。SDS-PAGEによって分離された個々の分子種は、分子量マー カー蛋白質の相対移動度から求めた千単位の分子量（K）で表示した。

結 果

1)可溶性画分中で相対含量の最も高い分子種は、DLPでは $67 \mathrm{~K} 、 \mathrm{VP} て ゙ は 16 \mathrm{~K}$ であった。

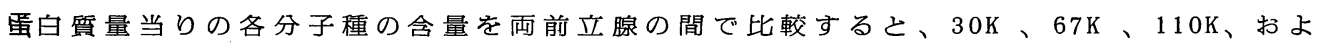
び $120 \mathrm{~K}$ dLP により多く含まれ、また、13K、14K、および $16 \mathrm{~K}$ はV VPに著しく多く含ま れていた。糖染色の結果から、VPの $16 \mathrm{~K}$ よび DLP の $120 \mathrm{~K}$ が糖蛋白質であることが明ら かとなった。2)ミクロソーム画分中で相対含量の高い分子種は、DLP では $65 \mathrm{~K} 、 105 \mathrm{~K}$ 打

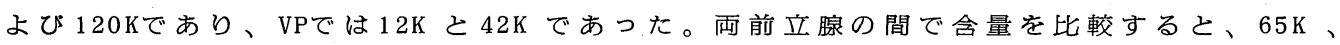

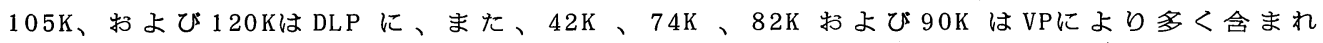
た。可溶性画分中に見出されたものと同一の糖蛋白質分子種が両前立腺のミクロソーム 画分中にも見出された。3)核蛋白質の中で、ヒストンはいずれの前立腺についても、2 種のH1ヒストン亜種を含む 7 種類に分離され、その含量と分子種は両者の間でほとんど 差がなかった。非ヒストン蛋白質 (NHP)の中で含量の高い分子種は、DLPでは $20 \mathrm{~K} 、 V P$

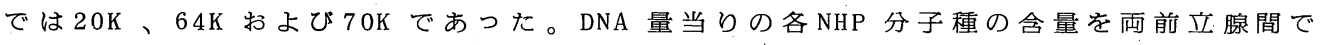
比較すると、いずれの分子種もDLP により多く含まれていたが、最も顕著な差は $20 \mathrm{~K} の$ 含量がDLPに約 7 倍高いことである。核画分においては、いずれの前立腺でも糖蛋白質 は検出されなかつた。

PMSF非存在下に調製した各画分を用いて、内在性プロテアーゼが泳動パターンに与え る影響を調べた結果、ミクロソームおよび可溶性画分では影響が見られなかったが、核 画分に颃て DLP、VPともにH1ヒストンとNHP の分解が観察され、アルカリプロテア 一ゼの存在が示唆された。また、この核蛋白質の分解はPMSFによって完全に阻害された。

上記の結果から、各細胞内画分は両前立腺に特改的な泳動パターンを示すこと、また、 この差異は両前立腺における内在性プロテアーゼの作用によるものでないことが示され た。 


\section{3. マウス涙液蛋白の電気泳動的モザイク \\ 松島 芳交・今井 忠治 (東北歯大·口腔診断) \\ 池本 卯典 (自治医大·人間生物)}

マゥス源液かボリアクリルアミドゲル電気泳動像に見出された変異蛋白型（Mouse tear protein system-3:Mtp-3）

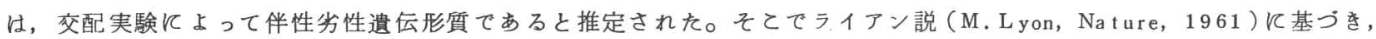
左右両眼の涙液を別々飞採取し, 泳動したとてろ $\mathrm{Mtp}-3$ 遺伝子についてへテロ接合体の雌にモザイクを認的た。

材料お上び方法：マウスは 16 近交系 ( $\mathrm{A} / \mathrm{He}, \mathrm{AKR}, \mathrm{BALB} / \mathrm{c}, \mathrm{CBA}, \mathrm{CL} / \mathrm{Fr}, \mathrm{C} 3 \mathrm{H} / \mathrm{He}, \mathrm{C} 57 \mathrm{BL} / 6, \mathrm{C} 57 \mathrm{~L}, \mathrm{DBA} / 2, \mathrm{DDD}, \mathrm{KK}$, $\mathrm{NC}, \mathrm{NZB}, \mathrm{NZW}, \mathrm{WB} / \mathrm{Re}, \mathrm{WC} / \mathrm{Re}$ ) と近交系間交配マウスを用いた。試料はビロカルビン剌激にょって漏出した淚液を滤 紙片に吸着採取し, pH8.0の水平式ボリアクリルアミドダル電気泳動法 (Balakrshinan and Ashton, Am. J.Hum.Genet。 $1974)$ Kっって分離検出した。

結果および考察：Mtp-3はNZBのみスバンドを認め, 他の15 系は Mtp-3 域のバンドを欠落した。交配実験は,Mtp-3 域にバンドを有する系のNZBと，乙の域のバンドを欠落する系のBALB/cとを用いて行った。 Mt p - 域飞NZBと同様

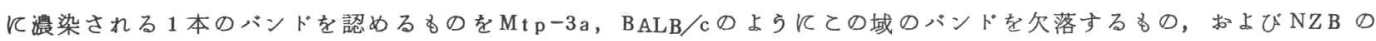

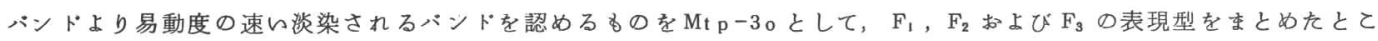

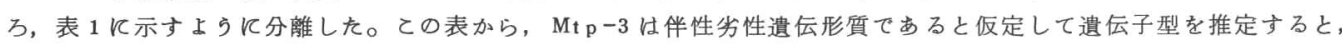

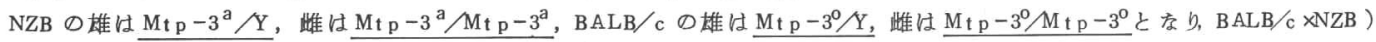
$F_{1}$ 雄は $\mathrm{Mtp}_{\mathrm{p}}-3^{\mathrm{O}} \mathrm{Y},(\mathrm{NZB} \times \mathrm{BALB} / \mathrm{c}) \mathrm{F}_{1}$ 雄は $\mathrm{Mtp}-3^{\mathrm{a}} / \mathrm{Y}$, $\mathrm{BALB} / \mathrm{c}$ と NBD正逆交配 $\mathrm{F}_{1}$ の雌はいずれ子 $\mathrm{Mtp}-3^{\mathrm{a}} /$ $\mathrm{Mtp}-3^{\mathrm{o}}$ と考えられる。

ライアン説によれば， $\mathrm{X}$ 連鎖遺伝子についてへテロ接合 体の雌では，2 個のX染色体のらち一方のX染色体の不活 性化汇とるない,その形質はモザイクの状態になるはずで ある。そてで左右両眼加ら涙液別々飞採取して泳動した ところ、Mt p-3o の雌は 55 例中 12 例飞モザイクを認めた。 モザイクは図 1 亿示すように $\mathrm{Mtp}_{\mathrm{p}}-3$ と $\mathrm{Mtp}_{\mathrm{p}}-2,-4$ にす 認 められ, 左右バントの易動度差, あるいは一方のバンドの 欠落によって表現された。また p -1およびてれより陽極 側飞泳動されるバンドにモザイクは認められず, とれらは 常染色体性であり，Mtp-2,-3,-4 は X染色体上飞連鎖し ていると推定された。因みに, へミ接合体口雄, ホモ接合 体の雌には，モザイクを1例子認奻なかった。

このようにモザイクは, 表現型が $\mathrm{Mt}$ p-3oのうち遺伝子 型の $\mathrm{Mt}_{\mathrm{t}}-3^{\mathrm{a}} / \mathrm{Mtp}_{\mathrm{t}}-3^{\mathrm{a}}$ 個体の一部反認められ, これ《 遺伝子の不活性化される割合によってモザイクを生ずるる Mtp-2 のと, 左右とるバンド死欠落して $\mathrm{Mtp}-3^{\mathrm{O}} / \mathrm{Mtp}-3^{\mathrm{o}}$ 個体と 判別されないるのとが生ず為と考えられた。てれらの結 果から, マゥ又源液蛋白飞見出されたモザイクは，線維芽 細胞クローン, 腫場細胞, 毛根などを試料とした電気泳動 法によって見出された G-6-PD， HGPRT，PGKなどの 生化学的モザイクと同様に, ライアン説を支持するるのと 考える。

Table 1. Distribution of mouse tear protein system-3 ( Mtp-3) in the $F_{1}, F_{2}$ and $F_{3}$ generations from matings of NZB- and $B A L B / c-s t r a i n$ mice.

\begin{tabular}{|c|c|c|c|c|c|c|}
\hline \multicolumn{2}{|c|}{ Mating } & \multicolumn{2}{|c|}{ Male } & \multicolumn{2}{|c|}{ Female } & \multirow{2}{*}{$\begin{array}{l}\text { No. of } \\
\text { animal }\end{array}$} \\
\hline Female & Male & $M \mathrm{tp}-30$ & $M t p-3 a$ & $M \mathrm{tp}-30$ & $M t p-3 a$ & \\
\hline \multicolumn{2}{|c|}{$F_{1}(B A L B / c \times N Z B)$} & 9 & 0 & $9(3)$ & 0 & 18 \\
\hline \multicolumn{2}{|c|}{$\mathrm{F}_{2}(\mathrm{BALB} / \mathrm{c} \times \mathrm{NZB})$} & 23 & 9 & $33(7)$ & 0 & 65 \\
\hline \multicolumn{2}{|c|}{$\mathrm{F}_{3}(\mathrm{Mtp}-30 \times \mathrm{Mtp}-3 \mathrm{a})$} & 5 & 1 & 71 & 1 & 14 \\
\hline \multicolumn{2}{|c|}{$\mathrm{F}_{1}(\mathrm{NZB} \times \mathrm{BALB} / \mathrm{c})$} & 0 & 4 & $6(1)$ & 0 & 10 \\
\hline
\end{tabular}

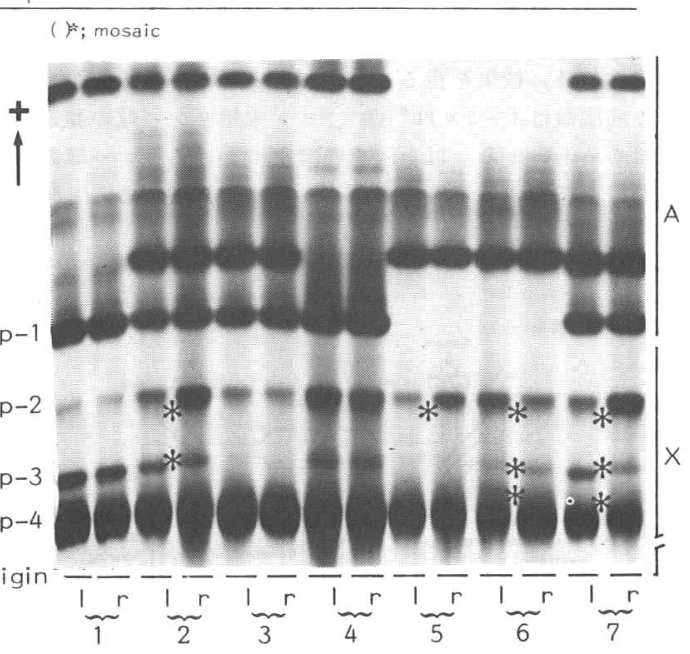

Figure 1.Polyacrylamide gel electrophoresis of mouse tear protein. Samples, left to right, 1) NZB female ,2) BALB/c $X$ NZB. $F_{1}$ female, 3-7) BALB/c $\times$ NZB. $F_{2}$ female. I : left eye, $\mathrm{r}$ : right eye. A : autosomal, $X: X$-linked. * : mosaic 


\section{○林＼cjkstart治久・小口義春・豊田教之・大原＼cjkstart稔・安藤隆雄・松木幹夫}

松永謙一・藤井雅彦・吉汲親雄・堀田鉄也・柳沢正昭

(呉羽化学)

森 武生 (都立駒込病院・外科)

岩口孝雄 (都臨床研・制癌)

従来, 或る抗原に対してリンパ球が感作されているかどらかを，マクロファーシ電気泳動テストにより間接的に測定 する方法がFieldらによって考案されたが，ての方法は可溶化抗原や指標細胞につ々てまだ多くの問題がある。一方， Sabolovic らによって, リンパ球は電気泳動法で2つのビークに分かれ，それぞれT， Bリンバ球に相当すると報告され て以来多くの研究がなされているが, 装置上の問題などがあり, 細胞電気泳動法が臨床㭘査法として確立するには至っ ていない。我々は，全自動細胞電気泳動装置（Parmoquant）を用いて担癌状態とおけるリンパ球表面荷電の変化を測定 し, 臨床応用への可能性につルて検討したので報告する。

\section{【方法】}

泳動装置は図 1 に示した如く細胞浮遊液を角型セルに自動吸引した後, 透析膜を通して直流電圧を引加し, 細胞の $\mathrm{X}$ 軸方向の動を暗視野照明法に上る顕微鏡 - TVカメラでとらえ, コンビュータ一処理により各細胞の刻々の位置を測定 するととによって電気泳動度を求めるものであり，結果は平均泳動度，個々の粒子の泳動度，ヒストグラム等が自動的 Kブリントアゥトされる。検索は(1) plasmacy toma X - 5563 皮下移植 $\mathrm{C} 3 \mathrm{H} / \mathrm{He}$ マウスの末梢リンパ球及び胸腺細胞(2) 正常人及び癌患者の末梢リンパ球を対象とした。末梢リンバ球は比重遠心法にょり，をた胸腺細胞は胸腺を摘出後 teasingを行々, すべて MEM Eagles 中で測定を行った。

\section{【結【果】}

マゥスの末梢リンパ球及び胸腺細胞の電気泳動を測定したととろ，担癌て伴って，末梢リンパ球では泳動度の低ら細 胞が増加し, 胸腺細胞では逆に泳動度の高い細胞が増加した。さらにレクチン（PNA）分画した胸腺細胞を電気泳動し たところ, 担癌で増加する高泳動度の細胞はmature な PNA-細胞であるととがわかった。図 2 に正常人末梢リンパ球の 泳動パターンを示す。正常人は 0.7 付近 $\mu_{\mathrm{m}} / \mathrm{sec} / \mathrm{V} / \mathrm{cm}$ K小ビーク，1.0 付近大ビークを有する双峰性のパターンを示した。 さらに，乙の細胞をナイロンゥールカラム法で分離し，電気泳動及び，口ゼット法による $\mathrm{T} \cdot \mathrm{B}$ 細胞の測定を行ったとて ろ, 0.7 付近のビークは B 細胞, 1.0 付近のピークは T細胞であるととがわかった。癌患者の末梢リンパ球は図 3 の様な パターンを示し，一般的に低泳動度の細胞が増加する傾向がみられ，乙れはT в 比の測定から T細胞の表面荷電が減少 しているためであると推測され，癌患者の免疫能の低下を意味しているのではないかと思われる。

\section{【考察】}

この泳動装置は生理的メディウム中の細胞を全自動で短時間（５分間／100粒子）飞測定し,手動法に比べ客観的で再 現性の良い結果を得るととがでをるため, 電気泳動ヒストグラムの統計学的解析が可能となった。さらに, 測定に必要 な細胞数は $1 \sim 2 \times 10^{8}$ 個で, ヒト末梢リンパ球の測定の場合 $3 \sim 5 \mathrm{ml}$ の採血で十分であるため臨床的応用に適した方法 であるといえる。以上，担癌宿主におけるリンパ球電気泳動ヒストグラムを解析したととろ，本測定法は癌患者の免疫 動態を把握する可能性が高く，有効な方法であると思われる。

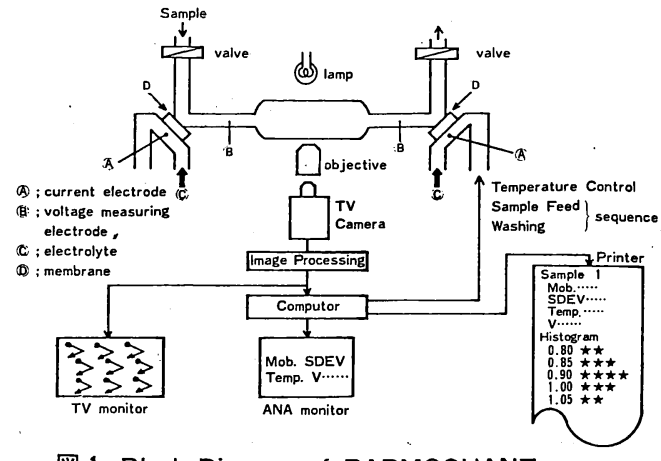

図 1 Block Diagram of PARMOQUANT

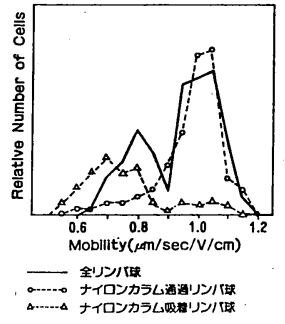

図 2 ナイロンファイバーカラム分離 ヒト末梢リンバ球の電気泳動パーン

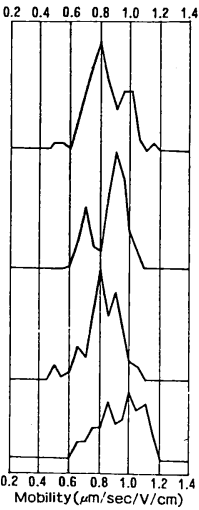

図 3 癌患者 末梢リンパ球 電気泳動/䧄ーン 
Vol. $2 \dot{6} \quad$ No. $1 \quad 1982(59)$

\section{5. 細胞電気泳動における絊毛機能検査 \\ ○吉田雄一郎・山田 正興・清水 亮一・大川 了氿・大川 公康 \\ (日本医大・第 1 産婦人科)}

妊娠は免疫学的立場からみると同種移植と考えられ母体にとって胎児は一種の移植組織とみなされる。それにもか かわらず拒絶を受けるととなく 10 ケ月間母体内で生育を続けるととは免疫学的に特異な現象であると思われる。子 宮内で胎児が死亡すると䋐毛が分解され免疫学的機序により拒絶されるすのと考えられる。とれは主として細胞性免 疫機序によると考えられるので, てれは早期に免疫学的機序にょっておてっている事をMSF ( Macrophage Slowing Factor)によって診断できるが，乙の方法壮繁雑であるのでタンニン酸ヒッジ赤血球に MSFを吸着させる細胞電気 泳動試験 (Tannic acid Erythrocytes Electrophoretic Mobility Test, TEEM-Test) を Shenton らは提唱した。 今回絨毛機能の一手段として殊に切迫流産の予后判定について TEEM テストにょる易動度の変化てついて検討した のでととに報告する。

<方法>(1)䄉毛抗原の抽出法（E.A. CASPARYの方法）：䋐毛のホモシネートを凍結乾燥しリポイドを除去し，PH 5 で沈溊するタンパクを採り，さらに PH 2.5 以下で沈澱する強アルカリ性のタンパクを採り，それを水に溶かし， 飽和硫安を加えて沈溊を透析し凍結乾燥したるのである。(2)リン゚球の培養試験：妊婦のリンパ球を分離して，

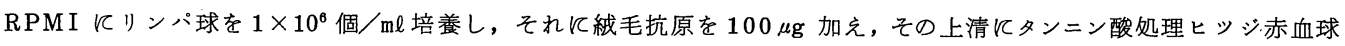
を入れ， $37^{\circ} \mathrm{C} 60$ 分以上インキュベイトし，その赤血球の移動度を判定した。

く成績>Table 1 は正常妊娠ならびに切迫流産予后良好, 不良例について行なった TEEMテストの結果で, 我々は 泳動遅延率 $7 \%$ 以上を陽性とした。正常妊娠では陽性率は $10 \%$, 切迫流産予后良好例で愓性率 $28.6 \%$, 予后不良 例では $70 \%$ と有意差のある移動度の遅延率を認めた。Table 2 は切迫流産予后不良例を示したすので子宮内の異常， 殊に切迫流産, 子宮内死亡では有意差のある遅延がみられた。症例く2>においては習慣性流産の患者であるが妊桭 7 週, 切迫流産の診断のあと入院加療していたか HCG 4,800 iu/l BスコープにてGSパターンを認め臨床症状る 軽快し臨床的予后良好例と思われたが, TEEMテストで $16.2 \%$ と著明な泳動遅延率を認め, 経過観察を行なってい た所,妊娠 10 週 HCG 6,400 iu/lと上昇したにるかかわらずTEEMテストは $21.5 \%$ と悪化を示し進行流産となった症例で ある。この方法により絨毛機能低下を従来のホルモンで測定するよりる早期に免疫反応が起っているすのと考えられた。

〈結論〉1. TEEMテストは臨床的飞有用な絨毛機能検査の一手段である。2. TEEMテストは切迫流産の予后判定 に有用である。3. 䄉毛が排除されるメカニズムは細胞性免疫が関与しているととが認められた。

TEEM test of normal pregnancy and threatened abortion

\begin{tabular}{|c|c|c|c|c|c|c|}
\hline \multicolumn{3}{|c|}{ Condition } & Data No. & $\begin{array}{c}\text { Negative } \\
>7 \%\end{array}$ & $\begin{array}{c}\text { Positive } \\
\leqq 7 \%\end{array}$ & \% Positive \\
\hline \multicolumn{3}{|c|}{$\begin{array}{l}\text { Normal Pregnancy } \\
\text { (first trimester) }\end{array}$} & 10 & 9 & 1 & $10.0 \%$ \\
\hline \multirow{2}{*}{$\begin{array}{l}\text { Abnormal } \\
\text { Pregnancy }\end{array}$} & 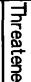 & $\begin{array}{l}\text { good } \\
\text { prognosis }\end{array}$ & 14 & 10 & 4 & $28.6 \%$ \\
\hline & 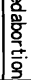 & $\begin{array}{l}\text { poor } \\
\text { prognosis }\end{array}$ & 10 & 3 & 7 & $70 \%$ \\
\hline
\end{tabular}

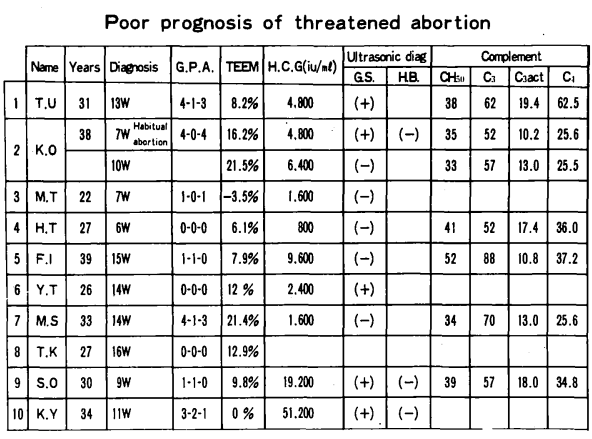

Table 2

参考交献 :

1) Caspary. E.A. \& Fieldi E. J. : Ann. N.Y. Acad. Sci, $122: 182,1965$

2) Shenton. B.K. et al. : J. Immunol. Methods, $14: 123,1977$

3）橋本信也：生物物理化学, $24: 209,1980$ 


\title{
46. 婦人科悪性腫瘍患者におけるタンニン酸羊赤血球電気泳動試験
}

\author{
一 第 2 報 -
}

○山田 正興・吉田雄一郎・大川 了仇・大川 公康

(日本医大・第 1 産婦人科)

目的：我々は第 32 回本学会総会において, 婦人科悪性腫湯患者におけるタンニン酸羊赤血球電気泳動試験(TEEMtest)について報告した。今回我々は, 単核球培養上清及びリンパ球単独培盖上清にょるTEEMーtestの易動度の 変化について検討すると共に, 追加症例につんて報告する。

方法：健常者及び悪性腫瘍患者より比重遠沈法により単核球を分離。特異抗原として Field \& Casparyの方法にょり, 成人脳組織より抽出した encephalitogenic protein (E.P.)を使用。各々の単核球につ々て,一方には E.P.添加, 他 方にはE.P. 無添加とし， 1 時間及び 24 時間培養。又, リンパ球を付着法により単核球より分離し, 同一操作にて 1 時間培養。その後の培姜上清につとて, TEEM-testを行った。タンニン酸羊赤血球はStavits Skyの方法により $4 \times 10^{8} / \mathrm{m} \ell$ K調整したものを使用。電気泳動装置は Cytopherometer（Zeiss）を用い, 泳動条件は $23{ }^{\circ} \mathrm{C}, 300 \mathrm{~V}$ 。 Hannigの triethanol amine buffer pH 7.2 飞浮遊した羊赤血球が顕微鏡下で一定距離移動する時間を測定。泳動 遅延率は $(\mathrm{Te}-\mathrm{Tc} / \mathrm{Tc}) \times 100$ で表現した。（ Te；E.P. 添加上清に上る泳動時間， Tc ； E.P. 非添加上清による泳動 時間) ( Fig. 1 )。

結果：単核球培養上清においては, 健常者に比し, 悪性腫湯患者において有意な泳動遅延率を認め, 1 時間培荃に比 し24 時間培養の方が羊延率は増強傾向を認めるるのの両者間に有意の差は認められなかった。リンパ球培盖上清に

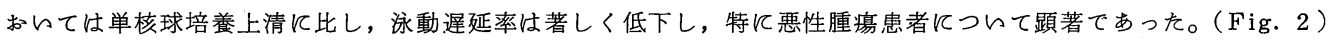

健常者 35 例, 良性腫湟患者 23 例, 覀性腫堭患者 102 例の単核球 1 時間培養上清につ々て, 泳動遅延率 $7 \%$ 以上 陽性と判定したとてろ，各々の陽性率は $2.9 \%, 8.7 \%, 88.2 \%$ あり，悪性腫湟患者において有意の易動度差を認め た。悪性腫瘍患者においては, 病期進行及び再発例において遅延率の増強傾向を認め, 逆に末期癌患者においては遅 延率の低下を認めた。（Table 1)

まとめ：TEEM-test 壮癌診断及び経過観察の上で，1つのパラメーターとして臨床的に有用と思われた。 electrophoretic slowing facter の発生にはリンパ球のみではなく，マクロファーシの存在が必要である可能性が 強いととが示唆された。

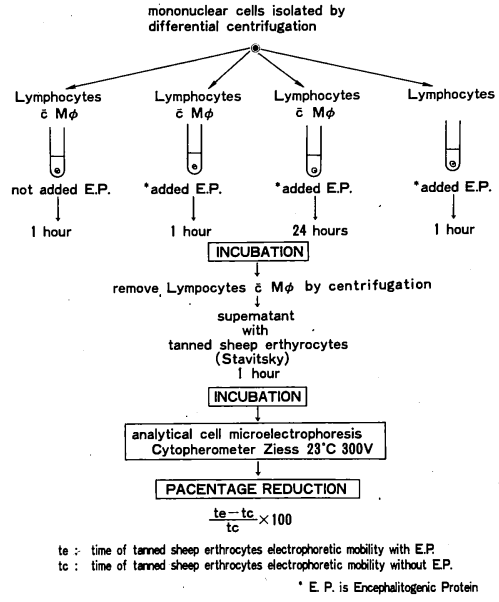

Fig. 1 Diagram of TEEM test

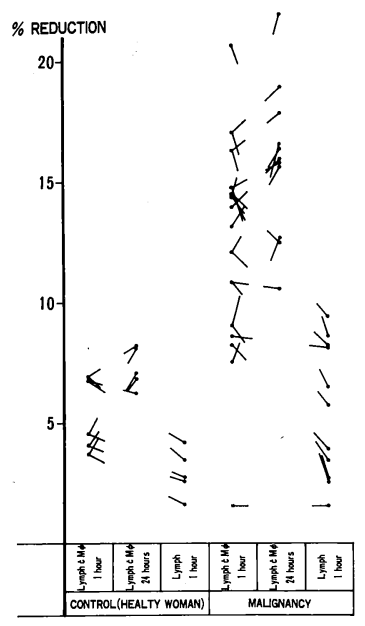

Fig. 2 Comparative study of TEEM test

参考文献:

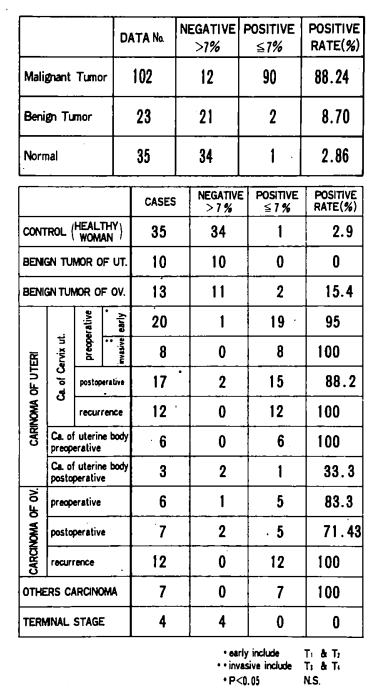

Table I TEEM test of gynecological malignancy

1) Caspary. E. A. \& Field. E. J. : Ann. N. Y. Acad. Sci, 122:182, 1965

2) Shenton. B. K. et al : J. Immunol. Methods, $14: 123,1977$

3）橋本信也: 生物物理化学, $24: 209,1980$

4) 山田正興 $5:$ 生物物理化学, $25: 187,1981$ 


\section{7. タンニン酸羊赤血球電気泳動に関する研究 第10報 \\ ○揚塩，正樹・堀田 正一・能势 俊一・小林 敏子・橋本 信也 \\ 阿部 正和(東京慈恵会医大 $\cdot$ 第 3 内科) \\ 蓮実 文彦 (東京慈恵会医大·輸血部)}

1970 年 Field \& Casparyは感作リンパ球を抗原で刺激し、その培養上清をモルモット腹腔内 マクロファージ作用させて、マクロファージの電気泳動を行った。との方法はマクロファー ジ電気泳動試験 macrophage electro phoretic mobilify test（MEM test）と呼ばれ、細胞 性免疫の新しい in vitro assay として登場した。1972 年Pritchard らは感度を良くするため、 改良法（MODーMEM）を考案した。しかしマクロファージは電気泳動的に不均一であるため、 indicator cell として用いるととが不適当であるととが指摘され、1975 年Porzsolt らにより タンニン酸羊赤血球が用いられるようになった。以後この方法は細胞電気泳動試験 electrophoretic mobility test（ EMT）と呼ばれ、広く普及するようになった。本法の基礎的、臨床 的検討は現在欧米におらて活発に行われている。

既に、私たちはPPDを用いて、ッベルクリン反応陽性者リンパ球を刺激してその培盖上清 により EMTを行らと、ッ反応陽性者では平均 $20.64 \%$ の遅延率を認めたが、ッ反応陰性者では 遅延がみられないととを報告した。をた、非特異的 mitogen である PHA や ConAでリンパ球を 刺激し、その培養上清で EMT を行うといづれる対照に比べてタンニン酸羊赤血球の電気泳動度 が著しく低下するととを認めた。更に OK－432、PSK、Levamisole、methyl B ${ }_{12}$ 、 polyAU、 poly IC、sodium periodateなどの immunopatentiatorにつ々て検討した成績も報告した。そて で正常者リンパ球を $\mathrm{T} 、 \mathrm{~B}$ 細胞に分けて PHAで刺激し、それぞれの培養上清で $\mathrm{EMT}$ を行らと、 $\mathrm{T}$ 細胞培盖上清の方が、 $\mathrm{B}$ 細胞培盖上清より遅延率が大をいてとを認めた。今回は正常者 $\mathrm{T}$ 細 胞、 $\mathrm{B}$ 細胞を ConA で刺激した培養上清につんて EMTを行った成績と、SLE 患者 $\mathrm{T}$ 細胞、B 細

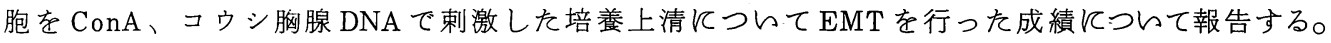

方法は末梢血よりリンパ球を分離し、更に rosett 形成法により T 細胞、non T 細胞に分け、 ConA あるいはコウシ胸腺 DNA を加えて培養し、その培養上清をETS ( tanned and sulphosalicylic acid stabilized sheep erythrocytes）に加えて細胞電気泳動を行った。細胞電気泳動装 置、泳動条件などはてれまで報告してをた通りである。泳動度の変化は対照として用いた非刺 激リンパ球培養上清によるETSの電気泳動度に対する低下率をるって表わした。

結果は正常者リンパ球を ConA で刺激した場合、 $\mathrm{T}$ 細胞刺激培盖上清による泳動遅延率は $\mathrm{B}$ 細 胞刺激培養上清のそれょりも著しく、PHAにおけると汪ざ同様であった。

SLE 患者リンパ球をConAで刺激した場合は、その遅延率は正常におけるよりや〉小さく、 しかも T細胞刺激培盖上清による遅延率の方が小さかった。しかし、DNAで刺激した場合は、 T 細胞培養上清飞よる泳動避延率は B 細胞培養上清のそれよりも大をいととが認められた。 


\title{
48. 胞状奇胎䋐毛内容液の血清蛋白解析
}

\section{萩原 啓二・小林 邦彦・塚原 正人・今泉 清・梶井 正}

\author{
(山口大 · 小児科)
}

\section{はじめに：}

胞状奇胎はヒト異常妹娠の 1 つで, 甚しく腫脹した絨毛が子宮腔内を満たし胎児, 臍帯, 羊 水, 羊膜をも欠く。絨毛内には, 粗な間質網と液体があるが, 血管は存在しない。従って液体 成分に含まれる蛋白は，(1)䋐毛卜ロホブラストが合成したものか，(2)母体血から移行したかで ある。Makayらは沪紙電気泳動を用い内容液の蛋白分画が母体のそれに似ていることを発見し た。 Marque ZーMonterらは, 内容液と母血清についての免疫グロブリン， $B_{1} C$ 濃度の測定結 果から奇胎卜ロホブラストの pinocytosisによって，IgG が選択的に絨毛内にとりこまれてい ると考えた。奇胎䄉毛を正常絨毛のモデルと見なし, 母血清と奇胎絨毛内容液について血清蛋 白（IgGを含む）の解析を行なった。

方法・結果 :

1. 䄉毛内容液, 母血清の二者構成蛋白を $7.5 \% \mathrm{~S} \mathrm{DS}-\mathrm{PAGE}$ (Weber \& O sborn の方法) 及 び免疫電気泳動法で比較したところ類似パターンを示した（図 1，図 2 )

2.免疫拡散法を用いて絨毛内容液 ( 8 例)に含まれる血清蛋白を 16 種の抗ヒト特異血清で調 べたところ全て認められ，一方，胎盤蛋白である $\mathrm{SP}_{1}$ も同定できた。

3. Ig G を含む 7 種の血清蛋白濃度 ( C P, Tf , Hx, $\alpha_{1} \mathrm{AG}, \alpha_{1} \mathrm{AT}, \alpha_{1} \mathrm{ACT}$ ) をMancini法を 用いて内容液と母血清について測定した（25 組）。各蛋白の内容液／母血清・濃度比とそれら の分子量の関係をみたところ負の対数直線回帰学認めた（相関係数 0.860 ）（図 3 ）。この) 結果から奇胎絨毛内容液の血清蛋白成分および I g G などの免疫グロブリンは, 母体からトロホ ブラストを介し，単純拡散により取り込をれたものと結論した。

考案 :

1.正常のヒト・トロホブラストにおいても, 奇胎絨毛のそれと同じく単純拡散でこの細胞を 介し，母血清蛋白が移行しているとすれば， IgGの胎盤における選択性を司どる部位は，卜 ロホブラストでなく胎児側の他の部位（血管内皮など）に存在する可能性を示唆している。

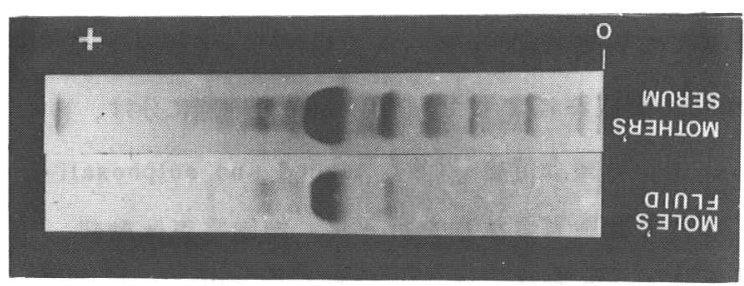

Fiq 1. 7.5\% SDS-Polyacrylamide electrophoresis

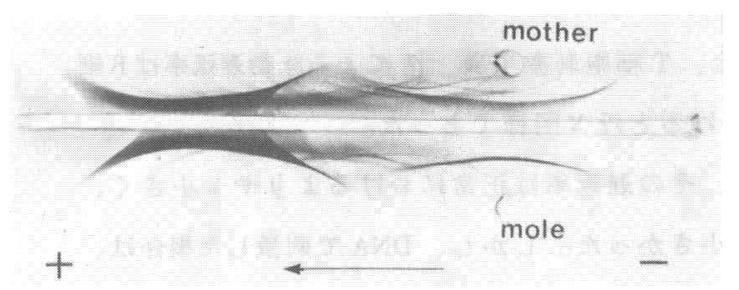

Fig 2. Immunoelectrophoresis

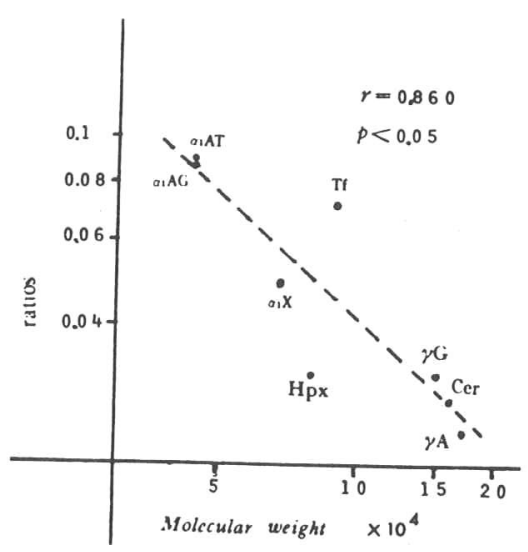

Fig 3. Logarithmic regression of molecular weight versus the ratio 


\section{9. 培養細胞表面の Transferrin Receptor の特異性と Subunit 構造 \\ ○福島 誠・添崎洋一・高後 裕・新津洋司郎・漆崎一朗 \\ (札㹸医大 $\cdot$ 第 4 内科)}

Transferrin receptor ( T . R 。 ) は， transferrin から細胞内への鉄イオンの渾搬に重要な 役割在果すと考えられ，従来鉄利用の盛んな幼若赤血球や胎盤㳊関する研究がおとなわれ てをたが，鉄眝蔵をになら肝細胞沉関する報告汢少ない。そとで今回汢，肝由来培養細胞 （Chang liver cell，H C - 4 ) 在用的，慢性骨髄性白血病由来細胞（Ｋ５62），網状球 を対照として, 細胞膜表面の T.R。の存在を確認し，更に電気泳動的に subunit 構造の検 討を和てなったので報告する。

$<$ 方法 $>$

ヒト transferrinは，塩化第二鉄にて飽和した pooled human plasma を $35 \sim 65 \%$ 硫安沈澱 後, D E A E セルロース・カラム・クロマトグラフィ一, 高速液体クロマトグラフィール て salmon pink の分画存回权，8２2\% polyacrylamide gradient gel 電気泳動後 con A

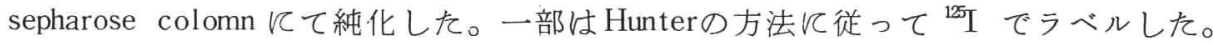

培養細胞としては, 肝細胞由来のヒトChang liver cell, hepatoma cell line (HC-4), 骨髄由来のヒトK 562 などを用いた。

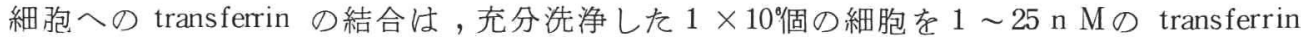
( ${ }^{15} \mathrm{I}$ - transferrinとして 2 万 cpm ) とともに $37^{\circ} \mathrm{C} 30$ 分間 incubation 後, 細胞老洗浄し， 細胞に結合している放射活性を測定，Scatchard plot解折にて細胞 1 ケ当りの receptor数， transferrin との親和性を算出した。

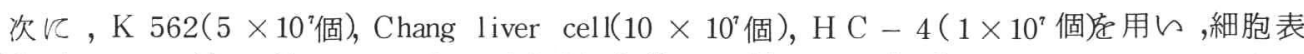
面を lactoperoxidase 法にて surface labelした後, cold transferrin飞て receptor を飽和， 洗浄後，1％Triton X-100 含むbuffer 中で， sonicatorを用い細胞膜を可溶化した。更 飞超遠心後の上清飞抗 transferrin 抗体を加之, incubate 後, Protein A t表面にもつ staphylococcus aureus 有々て免疫沈降を施行した。免疫沈降物は, S D S 電気泳動（4 $\sim 22 \%$ polyacrylamide gradient gel, $0.1 \%$ S D S ) 老施行し, 更飞 transblotting electrophoresis にてゲル内蛋白質をニトロセルロース・ペーパース転写した後，オートラシオグ ラフィーを10日間施行した。

$<$ 結果 $>$

(1)Chang liver cell の細胞 1 ケ当りの receptor 数は $0.8 \sim 1.0 \times 10^{5} /$ cell, H C -4 は 2.0 〜 3. $0 \times 10^{5} /$ cell で, ヒト hepatoma cell lineで有意の増加をみとめた。結合定数 $(\mathrm{Ka})$ は いづれも $1.5 \sim 4.0 \times 10^{\circ} \ell /$ と活低一定の強い結合親和性をみとめた。

(2) S D S 電気泳動飞よる transferrin receptor の subunit 構造の分析では， chang liver cell,

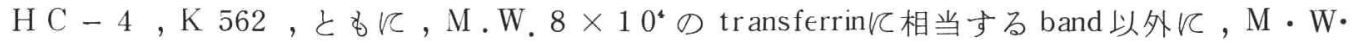
$12 \times 10^{4}, 3.5 \times 10^{*}, 2.5 \times 10^{*} ， 2 \times 10^{4}$ の部分飞4 本の共通する band 孝認め，乙れらは transferrin receptor $の$ su bunit と考えられる。 


\section{Epstein-Barr Virus（EBV）エンベロープ蛋白の研究 \\ リセプタ一細胞へのVirus 結合性における役割 \\ ○小出 典男・Well. A., Klein, G., 有馬 罝勝・長島 秀夫（岡山大·医·第 1 内科） \\ (Dept. Tumor Biology, Karolinska Inst. Sweden )}

\section{( 目的)}

Epstein-Barr Virus（EBV）は伝染性単核症をひき起し，さらにAfrican Burkitt’s. lymphomaやnasopharingeal carcinoma の発症に強く関連しているとと が知られている。EBVはT-lymphocyteには結合性を示さずBcell lineage の細 胞にのみ結合し感染する。virus の B-cellへの結合様式の詳細は不明であるが, 近 年 virus 構成成分は広く研究されるようになってきた。virus envelope の構成成分は Bcellへの結合に重要な役割を果していると考えられる。私たちはvirus envelope 構成成分を分析し, どの成分がこのリセプタ一結合性の役割を担っているかを検討 した。

\section{（方法）}

EBVはvirus producing B 9 5-8 細胞の培養上清から, DolyniukらのDextran 比重遠心法により精製した。virusの放射標識はメディウムに ${ }^{3} \mathrm{H}$-Thymidine や ${ }^{35} \mathrm{~S}$-Methionineを添加培養するととによるか, 精製virusをchloramin T 法か lactperoxidase 法により標識した。さらに，放射標識糖による metabolicなラベリン グや $\mathrm{NaB}^{3} \mathrm{H}_{4}$ を用いた external 放射糖標識法により, envelope 糖蛋白についても検 討を加えた。放射標識 virus の構成成分はSDS-PAGEにより分析した。Virus envelope は精製 virus をTriton x-100 で可溶化後, Dextran 此重遠心法により nucleocapsid と分離し, さらに envelope 成分は Sephacryl S-300 カラムクロマト 法により分画した。各virus 蛋白構成成分はS DS-PAGEにより分析するとともに virus 特異性は抗 E B V 抗体陽性ヒト血清を用いての免疫沈降反応で確認した。分画 した envelope構成成分はリポゾームに組み込ませたのち receptor positive cell の結合性関与を, whole virusの結合阻害反応として検討した。

\section{( 結果)}

envelopeには, 5 つの主要蛋白成分が検出された。その分子量は, $350 \times 10^{3}$ $(\mathrm{VE}-1), 220 \times 10^{3}(\mathrm{VE}-2), 140 \times 10^{3}(\mathrm{VE}-3), 130 \times 10^{3}(\mathrm{VE}-4), 85 \times 10^{3}$ $(\mathrm{VE}-5)$ daltonであった。VE-4 以外は envelope 表面に露出していることが, Imetabolicと externalのラベリングパターンの比較から推測された。VE-1, VE-2 は, 糖の放射標識性から, 糖蛋白であるととがわかった。リ七プタ一結合性の検討 では, envelope に露出している 2 つ糖蛋白, VE-1, VE-2 が強く関与している ととが明らかになった。

なお結果の一部はすでに J.Virol.,41(1), 286-297,1982.に発表した。 